Prepared in cooperation with the Triangle Area Water Supply Monitoring Project Steering Committee

\title{
Occurrence and Distribution of Mercury in Streams and Reservoirs in the Triangle Area of North Carolina, July 2007-June 2009
}

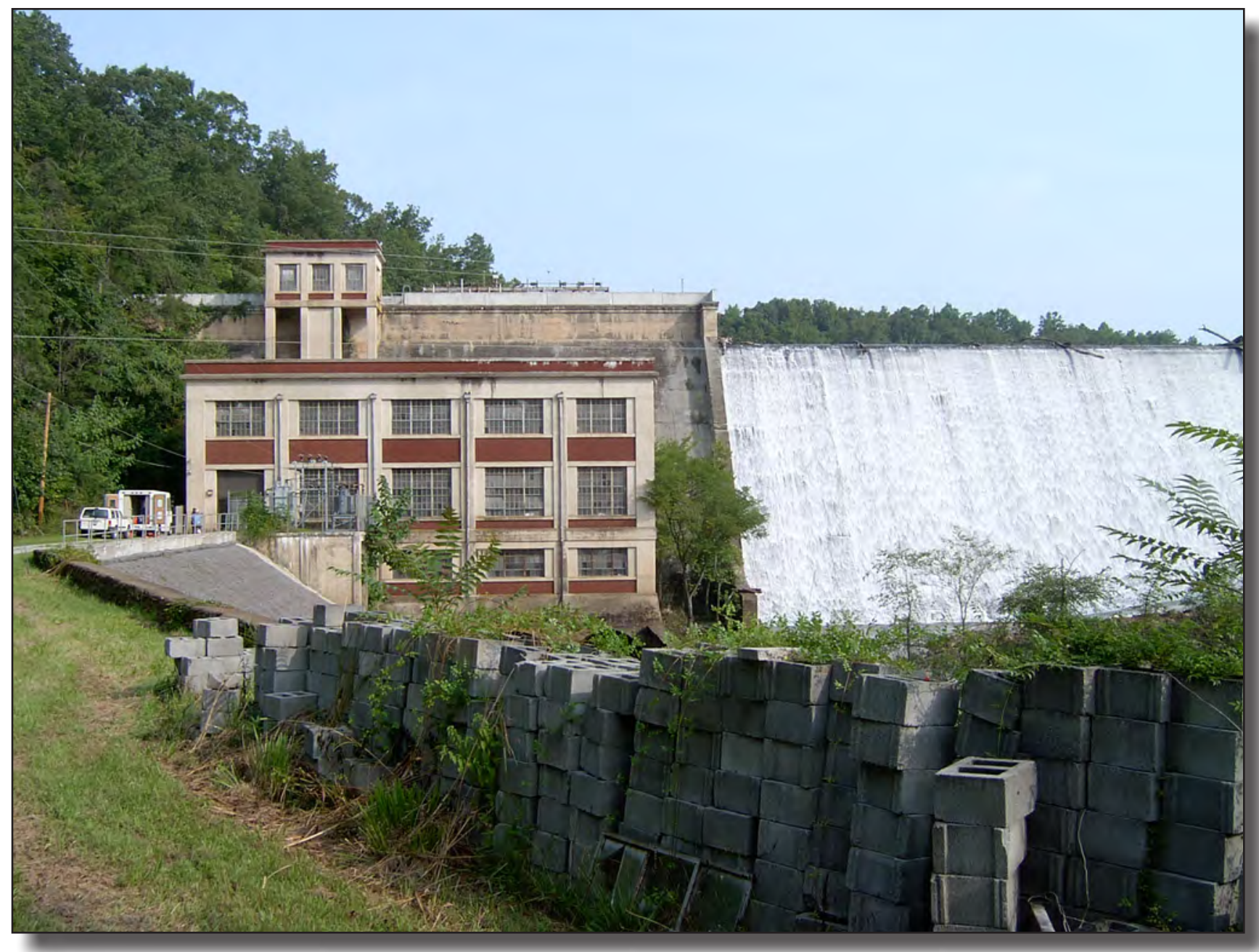

Scientific Investigations Report 2021-5027 
Cover. Lake Michie at dam near Bahama, North Carolina (U.S. Geological Survey streamgaging station 02086490). Photograph by Ryan B. Rasmussen, U.S. Geological Survey.

Back cover. Little River at SR1461 near Orange Factory, North Carolina (U.S. Geological Survey streamgaging station 0208521324). Photograph by Ryan B. Rasmussen, U.S. Geological Survey. 


\section{Occurrence and Distribution of Mercury in Streams and Reservoirs in the Triangle Area of North Carolina, July 2007-June 2009}

By Anna M. McKee, Sharon Fitzgerald, and Mary Giorgino

Prepared in cooperation with the Triangle Area Water Supply Monitoring Project Steering Committee

Scientific Investigations Report 2021-5027 


\section{U.S. Geological Survey, Reston, Virginia: 2021}

For more information on the USGS - the Federal source for science about the Earth, its natural and living resources, natural hazards, and the environment—visit https://www.usgs.gov or call 1-888-ASK-USGS.

For an overview of USGS information products, including maps, imagery, and publications, visit https://store.usgs.gov/.

Any use of trade, firm, or product names is for descriptive purposes only and does not imply endorsement by the U.S. Government.

Although this information product, for the most part, is in the public domain, it also may contain copyrighted materials as noted in the text. Permission to reproduce copyrighted items must be secured from the copyright owner.

Suggested citation:

McKee, A.M., Fitzgerald, S., and Giorgino, M., 2021, Occurrence and distribution of mercury in streams and reservoirs in the Triangle Area of North Carolina, July 2007-June 2009: U.S. Geological Survey Scientific Investigations Report 2021-5027, 42 p., https://doi.org/10.3133/sir20215027.

Associated data for this publication:

Fitzgerald, S.A., 2020, Water and bed sediment data associated with the occurrence and distribution of mercury in streams and reservoirs in the Triangle Area of North Carolina, July 2007 - June 2009: U.S. Geological Survey data release, https://doi.org/10.5066/P9S4EMC7.

ISSN 2328-0328 (online) 


\section{Acknowledgments}

Funding for this research was provided by the Triangle Area Water Supply Monitoring Project Steering Committee, which included the following North Carolina municipalities and agencies: Chatham County, Orange County, Town of Apex, Town of Cary, Town of Morrisville, Town of Hillsborough, City of Durham, Orange Water and Sewer Authority. The Triangle J Council of Governments provided collaborative and administrative support.

Pamela Reilly, Emily Majcher, and Daniel Calhoun provided insightful comments on the draft report. The authors wish to thank all field personnel and science-support staff who collected and quality assured water-quality data over the duration of the project. 



\section{Contents}

Acknowledgments ……...................................................................................................................

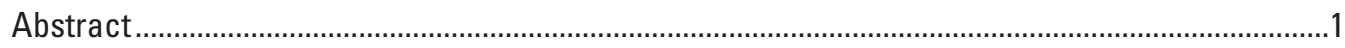

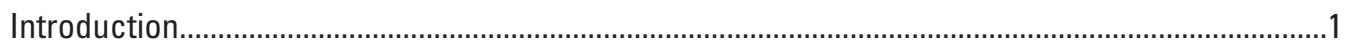

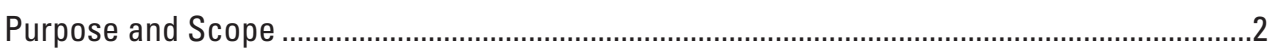

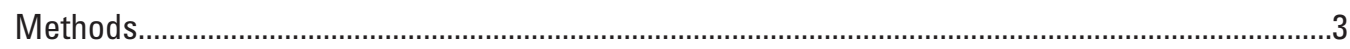

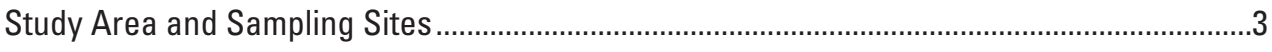

Sample Collection and Processing ........................................................................................

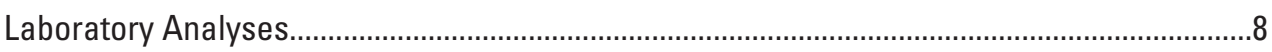

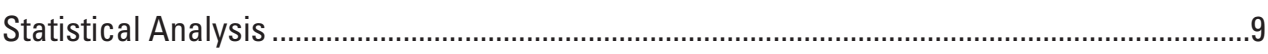

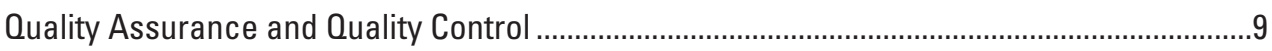

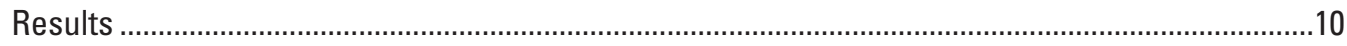

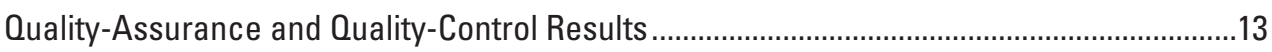

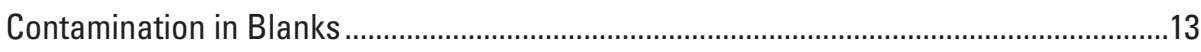

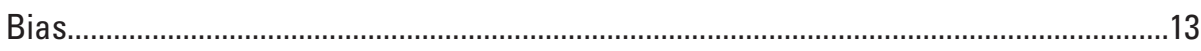

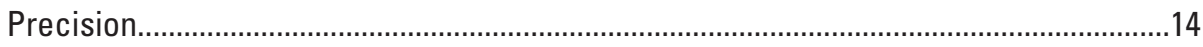

Water-Sample Mercury Detections, Concentrations, and Exceedances................................14

Seasonal Variation of Mercury Concentrations in Water Samples ........................................21

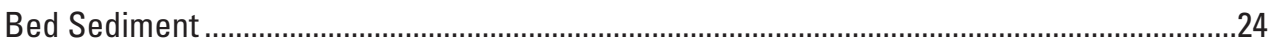

Ancillary Constituent, Precipitation, and Land-Use Associations with Median Mercury Concentrations in Water and Bed Sediment...............................................24

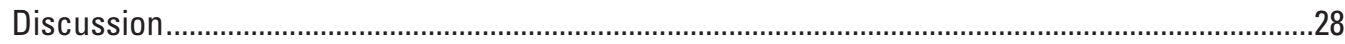

Trends in Mercury Concentrations in Water and Bed Sediment..........................................29

Comparisons of Mercury Concentrations with National and Benchmark Levels ...................31

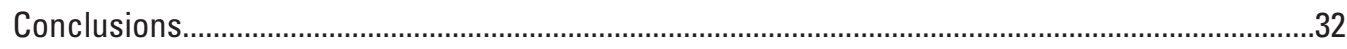

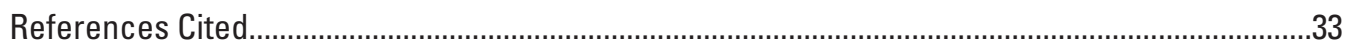

Appendix 1. Randomly Generated Numbers Below the Method Detection Level for Use in Statistical Analysis......................................................................................................

Appendix 2. Accuracy of Bed Sediment Total Mercury and Total Organic-Carbon Analyses Determined for Reference Materials ................................................................4

Appendix 3. Precision of Constituent Analyses in Replicate Water Samples................................42

\section{Figures}

1. Map showing location of Triangle Area Water Supply Monitoring Project data-collection sites.

2. Graphs showing number of reservoir-water samples by sample site and depth with filtered mercury and total recoverable mercury detections and concentrations that exceeded the North Carolina water-quality criterion for total mercury .

3. Graphs showing number of stream-water samples by sample site with filtered mercury and total recoverable mercury detections and concentrations that exceeded the North Carolina water-quality criterion for total mercury

4. Boxplot showing filtered mercury concentrations in reservoir-water samples, by sample site and depth. 
5. Boxplot showing total recovered mercury concentrations on log scale in reservoir-water samples, by sample site and depth

6. Boxplots showing filtered mercury and total recoverable mercury concentrations in stream-water samples, by sample site

7. Map showing percentages of reservoir-surface and stream-water samples with filtered mercury concentrations exceeding the North Carolina water-quality criterion for total mercury.

8. Map showing percentages of reservoir-surface and stream-water samples with total recoverable mercury concentrations exceeding the North Carolina water-quality criterion for total mercury.

9. Boxplot showing seasonal median (by site) filtered mercury concentrations for reservoir surface-water samples

10. Boxplot showing seasonal median (by site) total recoverable mercury concentrations for reservoir bottom-water samples 23

11. Map showing bed sediment bulk-calculated total mercury concentrations .25

12. Boxplot showing weekly average concentrations of total recoverable mercury in precipitation samples collected between 2007 and 2009 from the National Atmospheric Deposition Program site in Candor, North Carolina.

\section{Tables}

1. Study sites and land-use characteristics

2. Precipitation gage and number of water samples collected by season and the number of bed sediment samples collected at each site...

3. Laboratory-measured constituents in water and bed sediment samples. Minimum reporting level is defined as the smallest measured concentration of a substance that can be reliably measured

4. Numbers (and relative percentages) of quality-assurance and quality-control samples for each measured constituent relative to the number of environmental samples screened

5. Summary statistics for concentrations of mercury and ancillary constituents in water samples.

6. Number of water samples and sites with mercury-concentration detections and exceedances

7. Spearman correlations ( $\rho$ with $p$-value in parentheses) by season between reservoir-surface and reservoir-bottom mercury concentrations for concurrently collected samples

8. Number and percentage of samples with mercury-concentration detections and exceedances by waterbody type, sample depth, and season

9. Spearman rank correlations ( $\rho$, with $p$-value in parentheses) between median mercury concentrations and ancillary constituents for water samples

10. Spearman rank correlations (Spearman's $\rho$, with $p$-value in parentheses) for associations between seasonal median and overall median mercury concentrations and land use for reservoir and stream sites

11. Spearman rank correlations ( $\rho$, with $p$-value in parentheses) between bed sediment bulk-calculated total mercury concentrations and ancillary constituents for water samples collected simultaneously with bed sediment samples for reservoir and stream sites 
12. Spearman rank correlations ( $\rho$, with $p$-value in parentheses) for associations between bed sediment bulk-calculated total mercury concentrations and potential driver variables such as percentages of organic carbon in bed sediment, antecedent precipitation, drainage area, and land use

\section{Conversion Factors}

U.S. customary units to International System of Units

\begin{tabular}{|c|c|c|}
\hline Multiply & By & To obtain \\
\hline \multicolumn{3}{|c|}{ Length } \\
\hline inch (in.) & 25.4 & millimeter $(\mathrm{mm})$ \\
\hline foot $(\mathrm{ft})$ & 0.3048 & meter $(\mathrm{m})$ \\
\hline mile (mi) & 1.609 & kilometer $(\mathrm{km})$ \\
\hline \multicolumn{3}{|c|}{ Area } \\
\hline square mile $\left(\mathrm{mi}^{2}\right)$ & 2.590 & square kilometer $\left(\mathrm{km}^{2}\right)$ \\
\hline \multicolumn{3}{|c|}{ Flow rate } \\
\hline cubic foot per second $\left(\mathrm{ft}^{3} / \mathrm{s}\right)$ & 0.02832 & cubic meter per second $\left(\mathrm{m}^{3} / \mathrm{s}\right)$ \\
\hline
\end{tabular}

International System of Units to U.S. customary units

\begin{tabular}{|c|c|c|}
\hline Multiply & By & To obtain \\
\hline \multicolumn{3}{|c|}{ Length } \\
\hline millimeter (mm) & 0.03937 & inch (in.) \\
\hline meter (m) & 3.281 & foot $(\mathrm{ft})$ \\
\hline kilometer (km) & 0.6214 & mile (mi) \\
\hline \multicolumn{3}{|c|}{ Area } \\
\hline square kilometer $\left(\mathrm{km}^{2}\right)$ & 0.3861 & square mile $\left(\mathrm{mi}^{2}\right)$ \\
\hline \multicolumn{3}{|c|}{ Flow rate } \\
\hline cubic meter per second $\left(\mathrm{m}^{3} / \mathrm{s}\right)$ & 35.31 & cubic foot per second $\left(\mathrm{ft}^{3} / \mathrm{s}\right)$ \\
\hline
\end{tabular}

Temperature in degrees Celsius $\left({ }^{\circ} \mathrm{C}\right)$ may be converted to degrees Fahrenheit $\left({ }^{\circ} \mathrm{F}\right)$ as follows: ${ }^{\circ} \mathrm{F}=\left(1.8 \times{ }^{\circ} \mathrm{C}\right)+32$.

\section{Datum}

Vertical and horizontal coordinate information is referenced to the North American Datum of 1983 (NAD83).

Altitude, as used in this report, refers to distance above the vertical datum. 


\section{Supplemental Information}

Specific conductance is given in microsiemens per centimeter at 25 degrees Celsius $\left(\mu \mathrm{S} \cdot \mathrm{cm}^{-1}\right.$ at $25^{\circ} \mathrm{C}$ ).

Concentrations of chemical constituents in water are given in either milligrams per liter $\left(\mathrm{mg} \cdot \mathrm{L}^{-1}\right)$ or micrograms per liter $\left(\mu \mathrm{g} \cdot \mathrm{L}^{-1}\right)$. 


\title{
Abbreviations
}

\author{
Chloroa chlorophyll a \\ CV-AAS cold vapor-atomic absorption spectrometry \\ CV-AFS cold vapor-atomic fluorescence \\ DO dissolved oxygen \\ DOC dissolved organic carbon \\ FDA U.S. Food and Drug Administration \\ $\mathrm{FHg} \quad$ filtered mercury in water \\ $\mathrm{Hg}$ mercury \\ IQR interquartile range \\ irl interim reporting level \\ ISOG interim sediment-quality guideline \\ $<\quad$ less than \\ Irl laboratory reporting level \\ MDL method detection level \\ MeHg methylmercury \\ MRL method reporting level \\ $\mathrm{N} \quad$ number of samples \\ NADP National Atmospheric Deposition Program \\ NCWOC North Carolina water-quality criterion \\ NIST National Institute of Standards and Technology \\ NRC Nuclear Regulatory Commission \\ NWOL U.S. Geological Survey National Water Quality Laboratory \\ Pheoa pheophytin a \\ RPD relative percent difference \\ RSD relative standard deviation \\ SC specific conductance \\ SD standard deviation \\ $\mathrm{SO}_{4}{ }^{2-} \quad$ sulfate \\ SSC suspended-sediment concentration \\ TAWSMP Triangle Area Water Supply Monitoring Project \\ $\mathrm{THg} \quad$ total mercury in bed sediment
}




$\begin{array}{ll}\text { TOC } & \text { total organic carbon } \\ \text { TOC }_{\text {sed }} & \text { total organic carbon in bed sediment } \\ \text { TOC }_{\text {water }} & \text { total organic carbon in water } \\ \text { TRHg } & \text { total recoverable mercury (in water) } \\ \text { USEPA } & \text { U.S. Environmental Protection Agency } \\ \text { USGS } & \text { U.S. Geological Survey }\end{array}$




\title{
Occurrence and Distribution of Mercury in Streams and Reservoirs in the Triangle Area of North Carolina, July 2007-June 2009
}

\author{
By Anna M. McKee, Sharon Fitzgerald, and Mary Giorgino
}

\section{Abstract}

During the time period 2001-2006, the U.S. Geological Survey reported mercury-concentration measurements that exceeded the North Carolina water-quality criterion (NCWQC) of 0.012 microgram per liter for total recoverable mercury in streams and reservoirs across the Triangle Area of North Carolina. Mercury data were sparse, however, generally consisting of only one or two water samples per year. Additional monitoring and data analysis were needed to better determine the occurrence and distribution of mercury in the Triangle Area for all seasons and waterbody types as well as associations between mercury concentrations and waterquality and land-use parameters. Water at fifteen reservoir and 14 stream sites across the Triangle Area was sampled at various times between August 2007 and June 2009, with water samples collected from both the surfaces and bottoms of the water columns in reservoirs and from the surfaces of streams. A bed sediment sample was also collected at all reservoir sites and at all but one stream site. A total of 301 water samples was collected at reservoir sites. Filtered and total recoverable mercury were detected in at least one water sample collected from each reservoir site. A total of 77 water samples was collected from stream sites with filtered mercury detected in samples from one-half of these sites, and total recoverable mercury detected in at least one water sample from all but two sites. Total recoverable and filtered mercury concentrations exceeded the NCWQC for mercury more frequently in reservoir than in stream samples. Differences in sampling frequencies among seasons and between streams and reservoirs, however, may have negatively biased overall estimates of mercury concentrations in streams relative to reservoirs. Filtered mercury concentrations in surface-water samples from reservoirs and total recoverable mercury concentrations in bottom samples from reservoirs were highest in the fall, whereas no seasonal trends in filtered or total recoverable mercury were detected from stream samples. Total mercury concentrations were calculated for the bulk sample on the basis of the percentage of the grains in the bulk sample whose diameters that were smaller than 0.0625 millimeters. Total mercury concentrations in bed sediment were generally higher for samples from reservoir sites compared to streams sites, although the highest total mercury concentration in bed sediment was from a stream site. Concentrations of total recoverable mercury in water samples from stream sites all fell within the general range for streams and lakes without on-site significant anthropogenic sources (for example, mercury mines or industrial pollution), whereas samples collected from eight reservoir sites had total mercury concentrations in a range characteristic of sites affected by mercury mines or industrial pollution. Results suggested that litterfall may be a source of mercury in streams, whereas atmospheric deposition is likely a dominant source for reservoirs; however, high concentrations of filtered and total recoverable mercury concentrations in the fall season in some reservoir-water samples may warrant further analysis of potential hydrologic factors. Mercury concentrations in all water and bed sediment samples were below levels expected to cause adverse effects to humans and aquatic biota, indicating that mercury levels at the study sites in the Triangle Area were unlikely to cause an immediate health risk to humans or aquatic organisms. The high variability among several sample replicates for total recoverable mercury, however, indicated that inferences from total recoverable mercury concentrations can be tenuous.

\section{Introduction}

The human-health risks from dietary exposure to methylmercury (MeHg) are a large driver of public concern over mercury contamination in the environment and aquatic food webs. Methylmercury bioaccumulates in fish and can cause neurotoxic effects if consumed by humans, particularly in developing fetuses and young children. Whereas mercury in the environment can come from natural causes like volcanic eruptions, an estimated two-thirds of the mercury mass in the current global flux originated in anthropogenic emissions from industrial processes and gold mining (Mason and others, 1994). In the 1970s, the United States and other industrialized countries made concerted efforts to reduce intentional mercury discharges into surface waters (Turner and Southworth, 1999), which generally resulted in decreased mercury levels in fish 
and sediments at sites affected by industrial-mercury discharges (Wiener and others, 2003). The dispersion of mercury as a result of mercury cycling and atmospheric deposition, however, has resulted in mercury contamination even in areas in which no major anthropogenic source has ever been nearby.

Based on fish-tissue data routinely collected by the North Carolina (N.C.) Department of Environment and Natural Resources, a statewide advisory to limit or avoid consumption of fishes that could contain high levels of mercury was developed by the N.C. Department of Health and Human Services. Because of the statewide fish-consumption advisory, the State designated all named water bodies as impaired for mercury (North Carolina Department of Environment and Natural Resources, 2012). The U.S. Geological Survey (USGS), in partnership with local governments in the Triangle Area of North Carolina, has monitored mercury concentrations in streams and reservoirs since 1988 as part of a larger waterquality and streamflow-monitoring effort known as the Triangle Area Water Supply Monitoring Project (TAWSMP; Garrett and others, 1994).

From the inception of the mercury-monitoring program through 2001, mercury detections were rare in the Triangle Area. A methodological advancement in mercury detection and quantification implemented by the USGS National Water Quality Laboratory in 2001, however, improved the reporting level of by an order of magnitude from 0.1-0.2 microgram per liter $\left(\mu \mathrm{g} \cdot \mathrm{L}^{-1}\right)$ to $0.01 \mu \mathrm{g} \cdot \mathrm{L}^{-1}$ (Garbarino and Damrau, 2001). From 2001 to 2006, after the methods modification, mercury was frequently detected in the study streams and reservoirs, and in many instances total recoverable mercury (TRHg) was equal to or exceeded $0.012 \mu \mathrm{g} \cdot \mathrm{L}^{-1}$, the North Carolina water-quality criterion (NCWQC) for mercury in freshwater (North Carolina Department of Environment and Natural Resources, 2007). Additionally, the new-method detection level ${ }^{1}$ (MDL) of $0.005 \mu \mathrm{g} \cdot \mathrm{L}^{-1}$ (Garbarino and Damrau, 2001) was well below the NCWQC for mercury. The NCWQC for mercury was derived from the 1984 U.S. Food and Drug Administration (FDA) fish-tissue action level for protecting human health from the consumption of methylmercury in fish and divided by a mercury-bioconcentration factor (North Carolina Department of Environment and Natural Resources, 2012). Whereas the FDA fish-tissue action level was developed for methylmercury, the NCWQC for mercury applies to TRHg, which includes $\mathrm{MeHg}$, based on the logic that applying the criteria to TRHg would be protective of human health regardless of the proportion of TRHg was that was MeHg.

Whereas North Carolina does not regulate mercury concentrations in bed sediment, criteria (concentration limits) have been set by other States and countries. The Canadian Government recognizes 0.17 milligram per kilogram $\left(\mathrm{mg} \cdot \mathrm{kg}^{-1}\right)$ as the interim sediment-quality guideline (ISQG) for mercury and $0.486 \mathrm{mg} \cdot \mathrm{kg}^{-1}$ as the probable-effect level for aquatic biota

\footnotetext{
${ }^{1}$ Method detection level is the lowest concentration that can be measured and reported with $99 \%$ confidence that the analyte concentration is greater than zero (USEPA, 1997a).
}

in freshwater (Smith and others, 1996; Canadian Council of Ministers of the Environment, 1999). Ranges below the ISQG are defined as rarely associated with adverse biological effects in freshwater biota; values between the ISQG and probableeffect level are occasionally associated with adverse biological effects; and values above the probable-effect level are frequently associated with adverse biological effects (Environment Canada, 1997). MacDonald and others (2000) developed another set of guidelines for sediment-dwelling biota to account for uncertainties in the application of the existing published sediment-quality guidelines. In the revised criteria, MacDonald and others (2000) suggested that bed sediment mercury concentrations below the threshold-effect concentration of $0.18 \mathrm{mg} \cdot \mathrm{kg}^{-1}$ are not expected to cause adverse effects on sediment-dwelling organisms, but mercury concentrations in bed sediment above the probableeffect concentration of $1.06 \mathrm{mg} \cdot \mathrm{kg}^{-1}$ were expected to cause adverse health effects in sediment-dwelling organisms. The threshold-effect concentration $\left(0.18 \mathrm{mg} \cdot \mathrm{kg}^{-1}\right)$ is commonly used as the benchmark by States (in the United States) in which mercury concentrations in bed sediment are monitored (for example, U.S. Environmental Protection Agency [USEPA], 2010).

Until 2007, mercury data throughout the study area were sparse - in general, measured in only one or two water samples per year. Additional monitoring and data analysis were needed to better determine the occurrence and distribution of mercury in the Triangle Area and factors associated with differences in mercury concentrations. To assess the status of mercury in streams and reservoirs across the Triangle Area, an intensive synoptic assessment of the occurrence and distribution of mercury at 14 streams and 15 reservoirs was conducted from 2007 through 2009. Associations between mercury concentrations in water and bed sediment samples were investigated, and data related to potential driving factors including season, ancillary constituents, precipitation, and land use within the drainage areas were collected and analyzed. Information from this study could be used to identify locations with mercury concentrations of potential concern and to assess the spatial and temporal variability of mercury levels in the Triangle Area.

\section{Purpose and Scope}

The purpose of this study was to describe the occurrence and distribution of mercury concentrations and the frequency of exceedances of the NCWQC for mercury at selected reservoir and stream sites around the Triangle Study Area. A secondary objective was to investigate potential seasonal, ancillaryconstituent, precipitation, and land-use drivers associated with mercury concentrations in water and bed sediment. Nonpoint sources, including atmospheric deposition and surface runoff, were believed to be the primary sources of mercury in the study system (Sorensen and others, 1990; Fitzgerald and others, 1998; North Carolina Department of Environment and Natural Resources, 2012). Although North Carolina regulates mercury loads from permitted wastewater sites (National Pollutant Discharge Elimination System), these 
facilities generally contribute lower quantities of mercury to surface waters in North Carolina than does atmospheric deposition (North Carolina Department of Environment and Natural Resources, 2012). Geologic sources of mercury were not measured. ${ }^{2}$

\section{Methods}

\section{Study Area and Sampling Sites}

This study was conducted in the Cape Fear River basin upstream from the confluence of the Haw and Deep Rivers and in the Neuse River basin upstream from the dam at Falls of the Neuse Reservoir (hereafter referred to as Falls Lake; fig. 1). The study area encompassed five counties (Orange, Durham, Chatham, Granville, and Wake) that included the towns and cities of Apex, Butner, Carrboro, Cary, Chapel Hill, Creedmoor, Durham, Garner, Hillsborough, Morrisville, Raleigh, and the Research Triangle Park. Twenty-nine sampling sites were distributed among nine water-supply reservoirs, selected tributaries to those reservoirs (stream sites), and near a run-of-river public-water supply (categorized as a stream site; fig. 1, table 1). One reservoir site was located in each of seven small upland reservoirs, including Little River Reservoir, Lake Michie, Lake Butner, Lake Wheeler, Lake Benson, Cane Creek Reservoir, and University Lake. Two large, multipurpose reservoirs (Falls Lake and B. Everett Jordan Reservoir, hereafter identified as Jordan Lake; fig. 1) were each sampled at four sites.

\section{Sample Collection and Processing}

Since 1988, the USGS and TAWSMP have collected and analyzed water-quality samples from streams and reservoirs and collected continuous streamflow measurements from streams throughout the Triangle Area (Oblinger and Treece, 1996). Samples collected from sites for analysis were selected in 1988 as representative of water from major drinking-water supplies in the area and major tributaries to the drinking-water supplies (Oblinger, 2004). In 2007, supplementary mercury sampling was added to the scheduled sampling activities at USGS stations, and the number of samples collected at each site during the study period of July 2007 to June 2009 varied from 1 to 24. Fifteen reservoir sites were sampled either 8 or 12 times (table 2), at two depths ("surface": 1 meter (m) below the surface; "bottom": $1 \mathrm{~m}$ from the bottom of the reservoir). Fourteen stream sites were sampled 1 to 12 times each over the duration of the study (table 2) with one sample collected at each site from the surface of the water column. One bed sediment sample was collected at each site during the season of spring 2009 for all sites with one exception (USGS 02098198; table 2) at which

\footnotetext{
${ }^{2}$ The measurement of geologic mercury in the underlying bedrock was beyond the scope of this study. Horowitz and Stephens (2008) suggested that, relative to anthropogenic activities, the underlying rock type is unlikely to substantially influence sediment-associated mercury concentrations.
}

sample collection was not possible because of the high stream velocity. A total of 301 water samples were collected from reservoir sites (151 from the surface and 150 from the bottom, table 2), with the total number of samples collected at each site ranging from 16 (8 samples each from the surface and the bottom, table 2) to 24 (12 samples each from the surface and the bottom, table 2). The number of water samples collected at each stream site ranged from 1 (sites 24 and 29, table 2) to 12 ( site 1, table 2), with a total of 77 water samples collected from stream sites.

Two mercury parameters in water were investigated: filtered mercury (FHg), which is an operational measure of mercury in a dissolved form or associated with particles and colloids smaller than 0.45 micron $(\mu \mathrm{m})$; and TRHg, which includes all forms of mercury (inorganic and organic), including FHg and mercury associated with particles larger than $0.45 \mu \mathrm{m}$. Methylmercury, which is the predominant species of mercury that accumulates in fish tissue (Krabbenhoft and Rickert, 1995), was not specifically measured, but was included in FHg and TRHg measurements. Total mercury in bed sediment (THg) was measured for comparison with national background and baseline levels as well as for comparison with concentrations associated with adverse health effects to aquatic biota. Ancillary factors measured at the time of sample collection and investigated for potential relationships with mercury concentrations included concentrations of dissolved oxygen (DO), $\mathrm{pH}$, and specific conductance (SC). Streamflow data (USGS, 2016b) were collected and analyzed in accordance with the Quality-Assurance Plan for Surface-Water Activities of the North Carolina Water Science Center (Rantz and others, 1982). Antecedent precipitation for a site was determined on the basis of total precipitation during three timeframes $(1,2$, and 7 days) prior to sample collection from the most proximal USGS precipitation gage (table 2).

Water and bed sediment sample collection and processing followed established protocols specified in the USGS "National Field Manual for the Collection of Water-Quality Data" (National Field Manual; USGS, variously dated). Water samples were collected and processed according to established "Clean Hands/Dirty Hands" protocols (USGS, variously dated). In addition, equipment-cleaning procedures, sample containers, and shipping procedures used in the study were those specified in the USGS National Field Manual (USGS, variously dated). These protocols, which were developed to prevent contamination of samples containing low-level concentrations of trace elements, have been used by the USGS in the TAWSMP since 1994 (Oblinger, 2004). Bed sediment samples were collected with an Ekman dredge at the reservoir sites. Five samples were collected within a small radius in order to capture small-scale variability at each site. The overlying water was removed, and approximately the upper 5 centimeters $(\mathrm{cm})$ of sediment were transferred in a Teflon beaker or Teflon spoon to a clean glass bowl. The bowl contents were then homogenized prior to removal of a sample aliquot for analysis. At the wadeable stream sites, samples of the upper $5 \mathrm{~cm}$ of sediment were collected in a short corer. Teflon sheets were used for in situ sectioning of the sediments at the top and bottom of the ring. 
Table 1. Study sites and land-use characteristics.

[Drainage area (square miles) and land-use variables (shown as percent coverage within drainage area) were all calculated in StreamStats (U.S. Geological Survey [USGS], 2016a). NA, catchment unable to be defined]

\begin{tabular}{|c|c|c|c|c|c|c|c|c|c|}
\hline $\begin{array}{c}\text { Map } \\
\text { no. }\end{array}$ & USGS station ID & Latitude & Longitude & USGS station name & $\begin{array}{c}\text { Drainage } \\
\text { area }\end{array}$ & $\begin{array}{c}\text { Impervious } \\
\text { surface }\end{array}$ & Urban & Wetland & Forest \\
\hline \multicolumn{10}{|c|}{ Stream sites } \\
\hline 1 & 02085000 & 36.0711 & -79.0956 & ENO RIVER AT HILLSBOROUGH, NC & 66 & 2.2 & 12.5 & 0.7 & 56.3 \\
\hline 2 & 02085070 & 36.0722 & -78.9078 & ENO RIVER NEAR DURHAM, NC & 142 & 2.8 & 17.8 & 0.5 & 59.2 \\
\hline 3 & 0208521324 & 36.1417 & -78.9192 & LITTLE RIVER AT SR1461 NEAR ORANGE FACTORY, NC & 78 & 0.6 & 5.9 & 1.0 & 59.7 \\
\hline 5 & 02085500 & 36.1828 & -78.8789 & FLAT RIVER AT BAHAMA, NC & 149 & 1.3 & 6.9 & 0.7 & 56.6 \\
\hline 8 & 02086624 & 36.1279 & -78.7983 & KNAP OF REEDS CREEK NEAR BUTNER, NC & 42 & 1.9 & 8.4 & 1.6 & 66.0 \\
\hline 9 & 02086849 & 36.0593 & -78.8325 & ELLERBE CREEK NEAR GORMAN, NC & 22 & 21.0 & 73.6 & 3.8 & 16.4 \\
\hline 11 & 0208700780 & 35.9865 & -78.7992 & LITTLE LICK CR AB SR1814 NR OAK GROVE, NC & 10 & 11.8 & 59.6 & 1.0 & 29.5 \\
\hline 17 & 02096846 & 35.9872 & -79.2061 & CANE CREEK NEAR ORANGE GROVE, NC & 8 & 0.3 & 4.4 & 0.1 & 72.8 \\
\hline 20 & 02097314 & 35.8850 & -78.9653 & NEW HOPE CREEK NEAR BLANDS, NC & 76 & 9.1 & 40.7 & 5.3 & 45.1 \\
\hline 21 & 0209741955 & 35.8722 & -78.9131 & NORTHEAST CREEK AT SR1100 NR GENLEE, NC & 21 & 14.9 & 56.9 & 3.7 & 33.7 \\
\hline 22 & 02097464 & 35.9236 & -79.1150 & MORGAN CREEK NEAR WHITE CROSS, NC & 8 & 0.4 & 5.3 & 0.2 & 69.9 \\
\hline 24 & 02097521 & 35.8611 & -79.0100 & MORGAN CREEK NR FARRINGTON, NC & 46 & 4.3 & 19.6 & 1.6 & 63.3 \\
\hline 26 & 0209782609 & 35.7603 & -78.9203 & WHITE OAK CR AT MOUTH NEAR GREEN LEVEL, NC & 12 & 8.1 & 33.2 & 5.8 & 43.3 \\
\hline 29 & 02098198 & 35.6494 & -79.0656 & HAW R BELOW B. EVERETT JORDAN DAM NR MONCURE, NC & 1,690 & 5.1 & 20.2 & 1.6 & 47.8 \\
\hline \multicolumn{10}{|c|}{ Reservoir sites } \\
\hline 4 & 0208524845 & 36.1150 & -78.8692 & LITTLE RIVER RESERVOIR AT DAM NEAR BAHAMA, NC & 97 & 0.7 & 6.9 & 0.9 & 58.5 \\
\hline 6 & 02086490 & 36.1508 & -78.8300 & LAKE MICHIE AT DAM NR BAHAMA, NC & 168 & 1.2 & 6.7 & 0.9 & 57.1 \\
\hline 7 & 02086569 & 36.1669 & -78.7722 & LAKE BUTNER AT DAM NEAR BUTNER, NC & 29 & 0.2 & 2.7 & 1.0 & 69.8 \\
\hline 10 & 02086920 & 36.0697 & -78.7792 & FALLS LAKE AT INTERSTATE 85 NEAR REDWOOD & 513 & 2.7 & 13.9 & 1.9 & 56.1 \\
\hline 12 & 0208703650 & 36.0153 & -78.6911 & FALLS LAKE AT STATE HWY 50 NR SANDY PLAIN, NC & 620 & 2.7 & 14.2 & 2.1 & 55.5 \\
\hline 13 & 0208708905 & 35.9786 & -78.6328 & FALLS LAKE AT STATE HWY 98 NR BAYLEAF, NC & 705 & 2.5 & 13.3 & 2.2 & 56.6 \\
\hline 14 & 0208718195 & 35.9414 & -78.5836 & FALLS LAKE ABOVE DAM AT FALLS, NC & 772 & 2.5 & 14.2 & 2.1 & 56.9 \\
\hline 15 & 02087588 & 35.6944 & -78.6939 & LAKE WHEELER ON SWIFT CREEK NEAR RALEIGH, NC & 36 & 10.8 & 55.7 & 1.5 & 31.4 \\
\hline 16 & 02087701 & 35.6625 & -78.6114 & LAKE BENSON AT DAM NEAR GARNER, NC & 66 & 9.5 & 47.9 & 2.6 & 33.9 \\
\hline 18 & 0209684980 & 35.9500 & -79.2411 & CANE CR RESERVOIR AT DAM NR WHITE CROSS, NC & 32 & 0.5 & 5.4 & 0.2 & 61.1 \\
\hline 19 & 0209699999 & 35.7053 & -79.0844 & B. EVERETT JORDAN LAKE, HAW R ARM NR HANKSCHAPEL & NA & NA & NA & NA & NA \\
\hline 23 & 0209749990 & 35.8969 & -79.0922 & UNIVERSITY LAKE AT INTAKES NR CHAPEL HILL, NC & 30 & 0.8 & 7.4 & 0.2 & 72.4 \\
\hline 25 & 0209768310 & 35.7989 & -79.0058 & JORDAN LAKE AT BUOY 12 AT FARRINGTON, NC & 231 & 49.0 & 33.5 & 4.8 & 3.1 \\
\hline 27 & 0209799150 & 35.7417 & -79.0192 & B.E. JORDAN LAKE AB US HWY 64 AT WILSONVILLE, NC & 285 & 6.7 & 29.7 & 4.6 & 50.8 \\
\hline 28 & 0209801100 & 35.7275 & -79.0428 & B.E. JORDAN LK AT BELLS LANDNG NR GRIFFINS XRDS, NC & NA & NA & NA & NA & NA \\
\hline
\end{tabular}




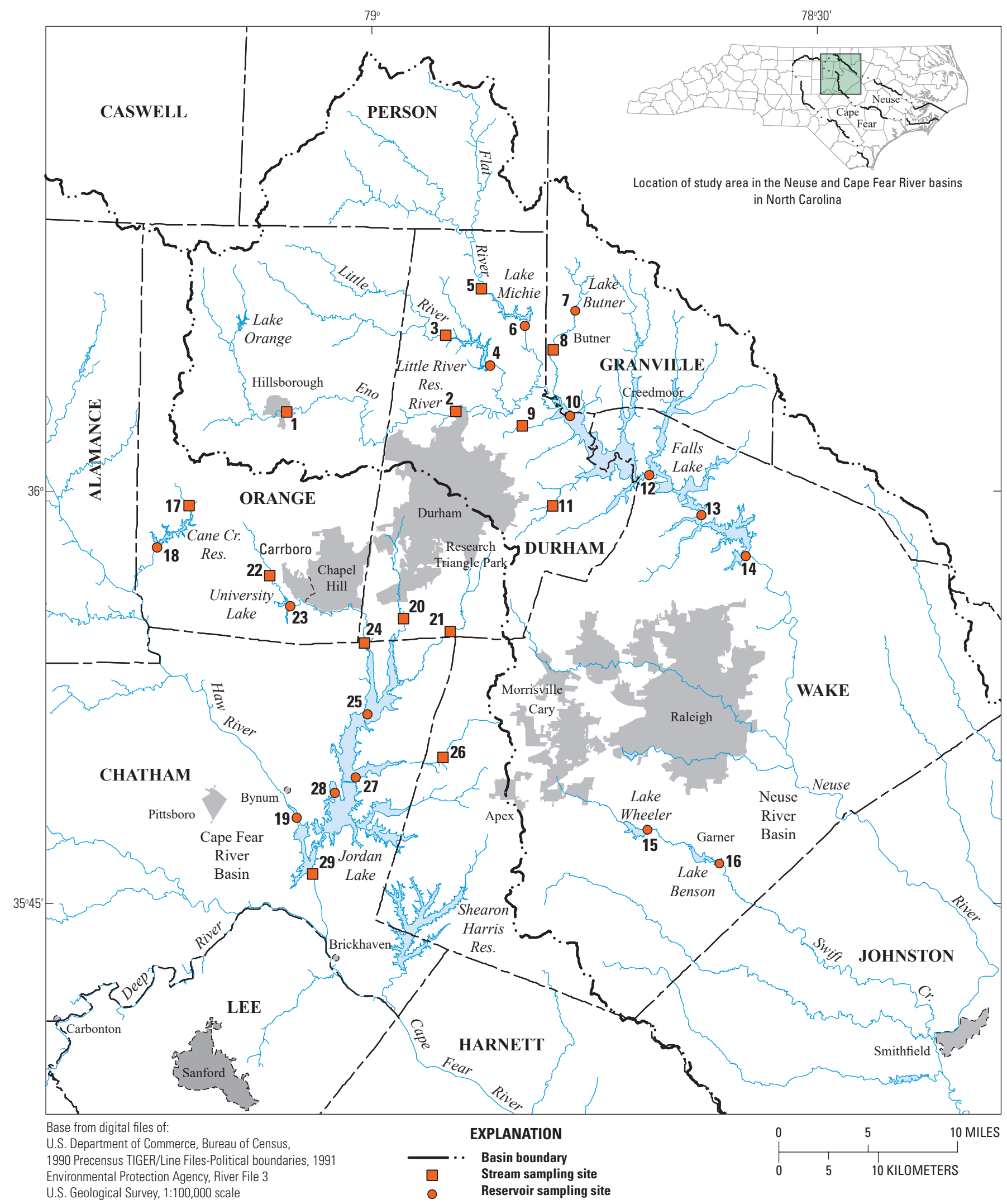

Figure 1. Map showing location of Triangle Area Water Supply Monitoring Project data-collection sites. 
Table 2. Precipitation gage and number of water samples collected by season and the number of bed sediment samples collected at each site.

[Site number refers to numbers on figure 1. Spring samples were collected in March-May; summer, June-August; fall, September-November; and winter, December-February. Abbreviations: USGS, U.S. Geological Survey; N, number of samples collected; NA, not applicable; surface, 1 meter below the surface of the reservoir water column; bottom, 1 meter from the bottom of ther reservoir]

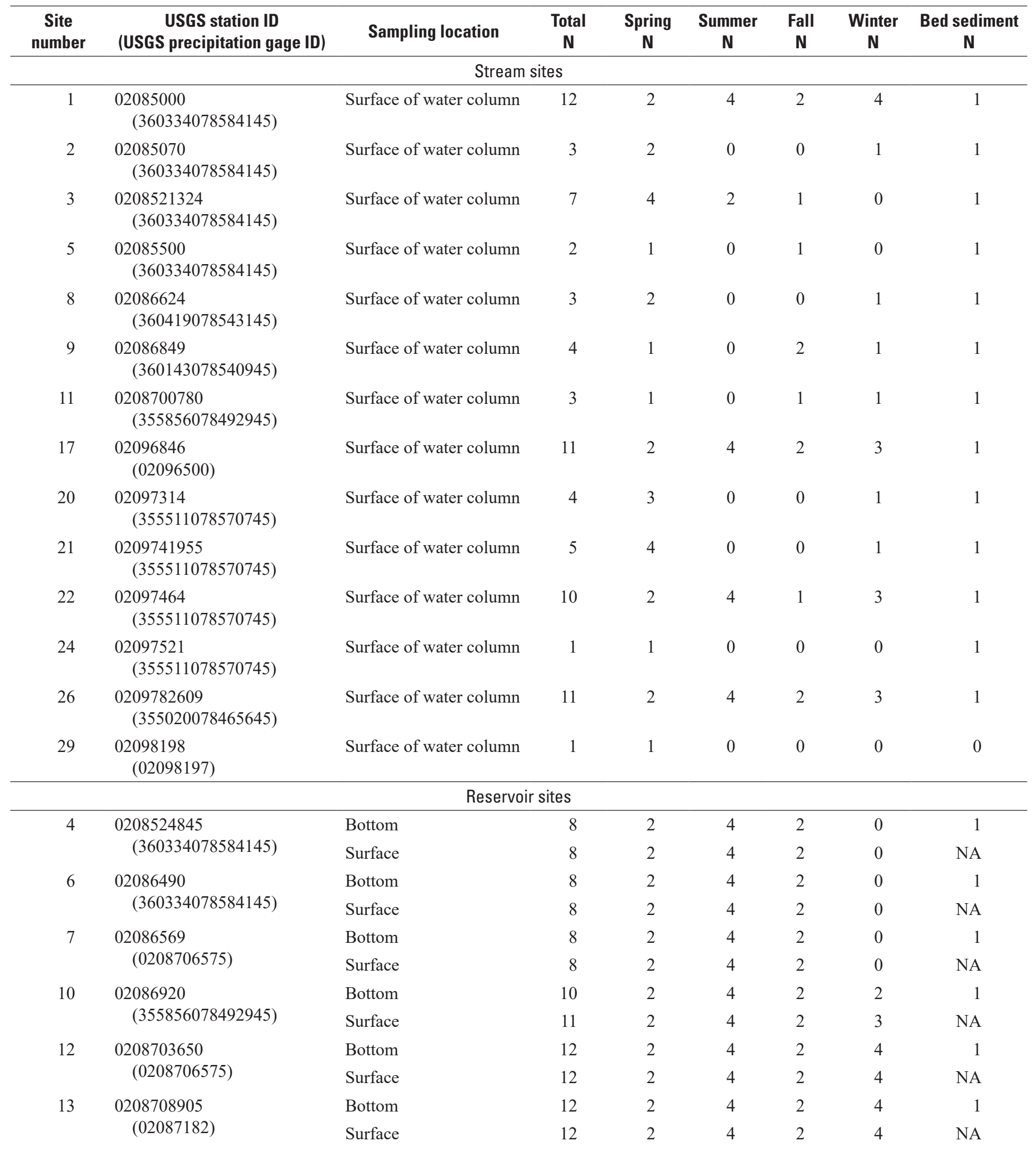


Table 2. Precipitation gage and number of water samples collected by season and the number of bed sediment samples collected at each site.-Continued

[Site number refers to numbers on figure 1. Spring samples were collected in March-May; summer, June-August; fall, September-November; and winter, December-February. Abbreviations: USGS, U.S. Geological Survey; N, number of samples collected; NA, not applicable; surface, 1 meter below the surface of the reservoir water column; bottom, 1 meter from the bottom of ther reservoir]

\begin{tabular}{|c|c|c|c|c|c|c|c|c|}
\hline $\begin{array}{c}\text { Site } \\
\text { number }\end{array}$ & $\begin{array}{c}\text { USGS station ID } \\
\text { (USGS precipitation gage ID) }\end{array}$ & Sampling location & $\begin{array}{c}\text { Total } \\
\text { N }\end{array}$ & $\underset{N}{\text { Spring }}$ & $\underset{\mathbf{N}}{\operatorname{Summer}}$ & $\begin{array}{c}\text { Fall } \\
\mathbf{N}\end{array}$ & $\underset{\mathbf{N}}{\text { Winter }}$ & $\begin{array}{c}\text { Bed sediment } \\
\mathbf{N}\end{array}$ \\
\hline \multicolumn{9}{|c|}{ Reservoir sites-Continued } \\
\hline \multirow[t]{2}{*}{14} & \multirow{2}{*}{$\begin{array}{l}0208718195 \\
\quad(02087182)\end{array}$} & Bottom & 12 & 2 & 4 & 2 & 4 & 1 \\
\hline & & Surface & 12 & 2 & 4 & 2 & 4 & NA \\
\hline \multirow[t]{2}{*}{15} & \multirow{2}{*}{$\begin{array}{l}02087588 \\
\quad(02087580)\end{array}$} & Bottom & 8 & 2 & 4 & 2 & 0 & 1 \\
\hline & & Surface & 8 & 2 & 4 & 2 & 0 & NA \\
\hline \multirow[t]{2}{*}{16} & \multirow{2}{*}{$\begin{array}{l}02087701 \\
\quad(354528078372645)\end{array}$} & Bottom & 8 & 2 & 4 & 2 & 0 & 1 \\
\hline & & Surface & 8 & 2 & 4 & 2 & 0 & NA \\
\hline \multirow[t]{2}{*}{18} & \multirow{2}{*}{$\begin{array}{l}0209684980 \\
\quad(02096500)\end{array}$} & Bottom & 8 & 2 & 4 & 2 & 0 & 1 \\
\hline & & Surface & 8 & 2 & 4 & 2 & 0 & NA \\
\hline \multirow[t]{2}{*}{19} & \multirow{2}{*}{$\begin{array}{l}0209699999 \\
\quad(02098197)\end{array}$} & Bottom & 12 & 2 & 4 & 2 & 4 & 1 \\
\hline & & Surface & 12 & 2 & 4 & 2 & 4 & NA \\
\hline \multirow[t]{2}{*}{23} & \multirow{2}{*}{$\begin{array}{l}0209749990 \\
\quad(355511078570745)\end{array}$} & Bottom & 8 & 2 & 4 & 2 & 0 & 1 \\
\hline & & Surface & 8 & 2 & 4 & 2 & 0 & NA \\
\hline \multirow[t]{2}{*}{25} & \multirow{2}{*}{$\begin{array}{l}0209768310 \\
\quad(355511078570745)\end{array}$} & Bottom & 12 & 2 & 4 & 2 & 4 & 1 \\
\hline & & Surface & 12 & 2 & 4 & 2 & 4 & NA \\
\hline \multirow[t]{2}{*}{27} & \multirow{2}{*}{$\begin{array}{l}0209799150 \\
\quad(02098197)\end{array}$} & Bottom & 12 & 2 & 4 & 2 & 4 & 1 \\
\hline & & Surface & 12 & 2 & 4 & 2 & 4 & NA \\
\hline \multirow[t]{2}{*}{28} & \multirow{2}{*}{$\begin{array}{l}0209801100 \\
\quad(02098197)\end{array}$} & Bottom & 12 & 2 & 4 & 2 & 4 & 1 \\
\hline & & Surface & 12 & 2 & 4 & 2 & 4 & NA \\
\hline
\end{tabular}




\section{Laboratory Analyses}

In addition to FHg and TRHg, ancillary constituents for water samples measured by laboratory analysis included organic carbon (dissolved, DOC; and total in water, $\mathrm{TOC}_{\text {water }}$ ), sulfate $\left(\mathrm{SO}_{4}{ }^{2-}\right)$, chlorophyll $a$ (Chloro $\left.a\right)$, and pheophytin $a$ (Pheoa); these constituents were analyzed at the USGS National Water Quality Laboratory (NWQL) in Denver, Colorado (table 3). Methylmercury was not measured separately from FHg and TRHg but, if present, would be included in the FHg and TRHg measurements. Suspended-sediment concentrations (SSCs) in stream samples were analyzed at the USGS Sediment Laboratory in Louisville, Kentucky (table 3). The clay and silt fraction of "fines" (particle diameters less than $63 \mu \mathrm{m}$ ) in bed sediment samples were analyzed for $\mathrm{THg}$ and total organic carbon in bed sediment $\left(\mathrm{TOC}_{\text {sed }}\right.$ ) (table 3 ) by total digestion at the USGS Georgia Sediment Partitioning Laboratory in Atlanta, Georgia.

Table 3. Laboratory-measured constituents in water and bed sediment samples. Minimum reporting level is defined as the smallest measured concentration of a substance that can be reliably measured.

[CV-AFS, cold vapor-atomic fluorescence spectrometry; CS analyzer, Carbon/Sulfur analyzer; CV-AAS, cold vapor-atomic absorption spectrometry; CAS, Chemical Abstracts Service; NA, not applicable; $\mu \mathrm{g} \cdot \mathrm{L}^{-1}$, microgram per liter; $\mathrm{mg} \cdot \mathrm{L}^{-1}$, milligram per liter; wt. \%, weight percent; $\mathrm{mg} \cdot \mathrm{kg}^{-1}$, milligram per kilogram; mrl, minimum reporting level; lrl, laboratory reporting level; irl, interim reporting level]

\begin{tabular}{|c|c|c|c|c|}
\hline Constituent & $\begin{array}{c}\text { Method and } \\
\text { instrumentation }\end{array}$ & CAS number & $\begin{array}{l}\text { Reporting level } \\
\text { and type }\end{array}$ & Reference \\
\hline \multicolumn{5}{|c|}{ Water samples } \\
\hline Mercury, filtered (FHg) & CV-AFS & $7439-97-6$ & $0.01 \mu \mathrm{g} \cdot \mathrm{L}^{-1} \mathrm{lrl}$ & (Garbarino and Damrau, 2001) \\
\hline Mercury, total recoverable (TRHg) & $\mathrm{CV}-\mathrm{AFS}$ & $7439-97-6$ & $0.01 \mu \mathrm{g} \cdot \mathrm{L}^{-1} \mathrm{lrl}$ & (Garbarino and Damrau, 2001) \\
\hline Sulfate $\left(\mathrm{SO}_{4}^{2-}\right)$ & Ion chromatography & $14808-79-8$ & $0.18 \mathrm{mg} \cdot \mathrm{L}^{-1} \mathrm{lrl}$ & (Fishman and Friedman, 1989) \\
\hline Chlorophyll $a^{1}$ (Chloro $\left.a\right)$ & Fluorometry & $479-61-8$ & $0.1 \mu \mathrm{g} \cdot \mathrm{L}^{-1} \mathrm{mrl}$ & (Arar and Collins, 1997) \\
\hline Pheophytin $a($ Pheo $a)$ & Fluorometry & $603-17-8$ & $0.1 \mu \mathrm{g} \cdot \mathrm{L}^{-1} \mathrm{mrl}$ & (Arar and Collins, 1997) \\
\hline Organic carbon, filterable (dissolved, DOC) & Infrared spectrometry & NA & $0.4 \mathrm{mg} \cdot \mathrm{L}^{-1} \mathrm{lrl}$ & (Brenton and Arnett, 1993) \\
\hline $\begin{array}{l}\text { Organic carbon, unfilterable (total, } \\
\text { TOC }_{\text {water }} \text { ) }\end{array}$ & Infrared spectrometry & NA & $0.6 \mathrm{mg} \cdot \mathrm{L}^{-1} \mathrm{irl}$ & (Clesceri and others, 1998) \\
\hline Suspended-sediment concentration (SSC) ${ }^{2}$ & Gravimetry & NA & $1 \mathrm{mg} \cdot \mathrm{L}^{-1} \mathrm{mrl}$ & (Fishman and Friedman, 1989) \\
\hline \multicolumn{5}{|c|}{ Bed sediment samples } \\
\hline Organic carbon, total $\left(\mathrm{TOC}_{\mathrm{sed}}\right)$ & $\begin{array}{l}\text { CS analyzer/infrared } \\
\text { detection }\end{array}$ & NA & 0.1 wt. $\% \operatorname{lrl}$ & $\begin{array}{l}\text { (Horowitz and others, } 2001 \text { and } \\
\text { references therein) }\end{array}$ \\
\hline Mercury, total digestion (THg) & CV-AAS & 7439-97-6 & $0.01 \mathrm{mg} \cdot \mathrm{kg}^{-1} \mathrm{lrl}$ & $\begin{array}{l}\text { (Horowitz and others, } 2001 \text { and } \\
\text { references therein) }\end{array}$ \\
\hline $\begin{array}{l}\text { Percentage of bed sediment smaller than } \\
0.0625 \text { millimeters }\end{array}$ & $\begin{array}{l}\text { Wet sieving, } \\
\text { gravimetry }\end{array}$ & NA & wt. $\%$ & (Horowitz and others, 2001) \\
\hline
\end{tabular}

${ }^{1}$ Reservoir samples only.

${ }^{2}$ Stream samples only. 


\section{Statistical Analysis}

Non-detections of FHg or TRHg in environmental water samples were substituted with randomly generated concentration values between 0 and the $\operatorname{MDL}\left(0.005 \mu \mathrm{g} \cdot \mathrm{L}^{-1}\right.$; appendix 1) (Antweiler and Taylor, 2008). For comparison with benchmark concentrations for bed sediment, measured THg concentrations were calculated for the bulk sample on the basis of the percentage of the grains in the bulk sample whose diameters were smaller than the sieve diameter of 0.0625 millimeters (herein referred to as bulk-calculated $\mathrm{THg}$ concentrations; data available from USGS, 2016b). Non-parametric analyses were used to investigate associations between potential driver variables and FHg and TRHg concentrations for water samples and bulk-calculated THg concentrations in bed sediment samples. Stream, reservoir-surface, and reservoir-bottom samples were investigated independently in all statistical analyses, except for correlation analyses between reservoir-surface and reservoir-bottom mercury concentrations.

Mercury concentrations may vary by season owing to factors such as seasonal differences in reservoir stratification and atmospheric deposition. To investigate potential seasonal stratification at the reservoir sites, correlations between reservoir-surface and reservoir-bottom mercury concentrations were investigated with Spearman rank correlations (statistical significance when $\mathrm{p}<0.05$ ) for both FHg and TRHg. Owing to the myriad of factors that can affect mercury fluxes and rates of mercury reactions, significant correlations between surface and bottom mercury concentrations would be consistent with mixing between surface and bottom samples, whereas a lack of correlation could indicate stratification. Seasonal differences in FHg and TRHg mercury concentrations were tested by using non-parametric Wilcoxon Tests with seasonal median values for each site. If a seasonal effect was detected (statistical significance when Chi-square $\mathrm{p}<0.05$ ) in FHg or TRHg concentrations, non-parametric Spearman rank correlations (described below) between potential driver variables and mercury concentrations in water were determined by using site-specific seasonal median values for mercury concentrations, antecedent precipitation, and ancillary constituents (all sites: DO, pH, SC, DOC, $\mathrm{TOC}_{\text {water }}, \mathrm{SO}_{4}{ }^{2-}$, Chloro $a$, Pheo $a$; stream only: SSC, streamflow). If no seasonal effect was detected in FHg or TRHg concentrations, Spearman rank correlations between potential drivers and mercury concentrations were calculated by using the overall median values by site. For bed sediment bulk-calculated THg analyses, Spearman rank correlations were determined with ancillary constituents measured in water samples collected concurrently with the bed sediment samples. (All bed sediment samples were collected during spring 2009.)

Drainage-area and land-use variables investigated for associations with mercury concentrations were calculated in StreamStats (USGS, 2016a) and based on 2006 National Landcover Data (Fry and others, 2011); these variables included urban area, forested area, impervious surface area, and wetland area. For analysis, land-use variables were calculated as a percentage of the drainage area (table 1). Directional associations between median mercury concentrations and ancillary constituents, antecedent precipitation, and land-use variables were investigated only if at least 50 percent of the median values for analysis were greater than the MDL. The interpretation of the value of the Spearman parameter $\rho$ was similar to that of Pearson's $r$, whose values are between -1 and 1 . The closer the value is to -1 or 1 , the stronger the correlation; a value of $\rho=0$ would indicate no correlation. Negative values indicate a negative directional association, and positive values for $\rho$ indicate a positive directional association.

Increasing the number of statistical comparisons on a dataset also increases the probability of a statistically significant result caused by chance (for example, rejecting the null hypothesis when it is true; referred to as a type I error). One way to reduce a type I error is to use a smaller value for $\alpha$, the maximum p-value for which a null hypothesis is rejected (for example, using $p<0.01$ instead of $p<0.05$ to indicate statistical significance). Error in the data caused by factors such as low precision in measured concentrations or high variability within the sample matrix may reduce the sensitivity of an analysis to detect a relationship if one is present (a type II statistical error-accepting the null hypothesis when it should be rejected). In this study, errors in water-sample mercuryconcentration data were likely, particularly for mercury concentrations below the method reporting level (MRL) and samples potentially affected by high variability in measured TRHg concentrations (described below). Statistical significance was therefore determined by $\mathrm{p}<0.01$, and potentially relevant associations were discussed if $\mathrm{p}<0.05$ for Spearman rank analyses. All statistics were analyzed by using the program JMP (v. 14.2.0, SAS Institute Inc.).

\section{Quality Assurance and Quality Control}

The contamination, bias, and precision of measured constituent concentrations in environmental samples were assessed by using equipment blanks, vehicle (ambient-open bottle) blanks, field blanks, reference standards, split replicates, and field replicates (table 4). Additionally, method performance at the NWQL was assessed during the study period from data collected by the USGS Quality Systems Branch (described in Mueller and others, 2015; data available from USGS, undated a). The various blanks reveal contamination from the sampling environment, sampling equipment, or processing and analysis. Reference standards have a known concentration and provide an evaluation of the analytical method. Field replicates were used to quantify the overall variability caused by sampling, processing, and analysis in measured concentrations.

Low accuracy or precision of constituent measurements in environmental samples may reduce the sensitivity of statistical analyses to detect associations between mercury concentrations and ancillary constituents and potentially determine 
whether or not a sample exceeds the NCWQC for mercury. The variability of sampling and analysis was assessed by using paired or triplicate sets of water samples (Fitzgerald, 2020). The precision levels of analyses of water collected in field replicates was evaluated in terms of relative percent difference (RPD, the absolute difference between replicate-pair concentrations divided by the average concentration multiplied by 100 ); relative standard deviation (RSD, the standard deviation of triplicate concentrations divided by the average concentration multiplied by 100); and absolute concentration differences among replicates. Replicate sets for which concentrations in all replicates were below the MDL (table 4) were assigned an RPD or RSD of 0 percent and an absolute difference of 0 concentration units. Mercury concentrations in replicate samples with measured concentrations below the method reporting level (MRL) (mercury was detected, but the measured concentration was estimated at a value below the MRL) were used in the same way as concentrations above the MRL in calculations. RPDs and RSDs less than 25 percent were considered to have acceptable reproducibility. The potential bias of $\mathrm{THg}$ and $\mathrm{TOC}_{\text {sed }}$ analyses in bed sediment samples was assessed through concurrent analysis of several reference standards with known concentrations. The precision levels of these analyses were determined from field and laboratory analytical replicates.

\section{Results}

Water-quality data presented in this report, including sample mercury concentrations, are available through the U.S. Geological Survey National Water Information System (USGS, 2016b) and are summarized for the entire study period in table 5.

Table 4. Numbers (and relative percentages) of quality-assurance and quality-control samples for each measured constituent relative to the number of environmental samples screened.

\begin{tabular}{|c|c|c|c|c|c|c|c|c|}
\hline Sample type & Constituent & $\begin{array}{c}\text { Number of } \\
\text { environmental } \\
\text { samples }\end{array}$ & $\begin{array}{l}\text { Equipment } \\
\text { blanks }\end{array}$ & $\begin{array}{c}\text { Vehicle } \\
\text { blanks }\end{array}$ & $\begin{array}{c}\text { Field } \\
\text { blanks }\end{array}$ & $\begin{array}{l}\text { Field replicate } \\
\text { sets }\end{array}$ & $\begin{array}{c}\text { Split } \\
\text { replicates }\end{array}$ & $\begin{array}{c}\text { Reference } \\
\text { materials }\end{array}$ \\
\hline \multirow[t]{6}{*}{ Water } & Total & 378 & $2(<1 \%)$ & $11(3 \%)$ & $11(3 \%)$ & $39(10 \%)$ & $0(0 \%)$ & $0(0 \%)$ \\
\hline & $\mathrm{FHg}$ & 378 & $1(<1 \%)$ & $10(3 \%)$ & $10(3 \%)$ & $13(3 \%)$ & $0(0 \%)$ & $0(0 \%)$ \\
\hline & $\mathrm{TOC}_{\text {water }}$ & 219 & $0(0 \%)$ & $0(0 \%)$ & $0(0 \%)$ & $13(6 \%)$ & $0(0 \%)$ & $0(0 \%)$ \\
\hline & Chloro $a$ & 148 & $0(0 \%)$ & $0(0 \%)$ & $0(0 \%)$ & $28(19 \%)$ & $0(0 \%)$ & $0(0 \%)$ \\
\hline & Pheo $a$ & 148 & $0(0 \%)$ & $0(0 \%)$ & $0(0 \%)$ & $28(19 \%)$ & $0(0 \%)$ & $0(0 \%)$ \\
\hline & $\mathrm{SSC}$ & 66 & $0(0 \%)$ & $0(0 \%)$ & $0(0 \%)$ & $3(5 \%)$ & $0(0 \%)$ & $0(0 \%)$ \\
\hline \multirow[t]{3}{*}{ Bed sediment } & Total & 28 & $0(0 \%)$ & $0(0 \%)$ & $0(0 \%)$ & $2(7 \%)$ & $3(11 \%)$ & $7(25 \%)$ \\
\hline & $\mathrm{THg}$ & 28 & $0(0 \%)$ & $0(0 \%)$ & $0(0 \%)$ & $2(7 \%)$ & $3(11 \%)$ & $7(25 \%)$ \\
\hline & $\mathrm{TOC}_{\text {sed }}$ & 28 & $0(0 \%)$ & $0(0 \%)$ & $0(0 \%)$ & $2(7 \%)$ & $3(11 \%)$ & $7(25 \%)$ \\
\hline
\end{tabular}


Table 5. Summary statistics for concentrations of mercury and ancillary constituents in water samples.

[Randomly generated concentration values between 0 and the method detection level (MDL, 0.005 microgram per liter $\left[\mu \mathrm{g} \cdot \mathrm{L}^{-1}\right]$ ) were substituted for nondetections in computations. Abbreviations: N, number of samples collected; SD, standard deviation; ND, not detected; NC, data for constituent was not collected; NA, not applicable; <, less than]

\begin{tabular}{|c|c|c|c|c|c|}
\hline \multirow{2}{*}{ Constituent } & \multirow{2}{*}{ Unit } & \multirow{2}{*}{ Statistic } & \multicolumn{2}{|c|}{ Reservoir } & \multirow{2}{*}{ Stream } \\
\hline & & & Surface & Bottom & \\
\hline \multicolumn{6}{|c|}{ Water } \\
\hline \multirow[t]{6}{*}{ Mercury, filtered (FHg) } & \multirow[t]{6}{*}{ Microgram per liter $\left(\mu \mathrm{g} \cdot \mathrm{L}^{-1}\right)$} & $\mathrm{N}$ & 151 & 150 & 77 \\
\hline & & Mean & 0.010 & 0.005 & 0.003 \\
\hline & & Median & 0.004 & 0.003 & 0.003 \\
\hline & & SD & 0.015 & 0.008 & 0.002 \\
\hline & & Minimum & ND & ND & ND \\
\hline & & Maximum & 0.099 & 0.071 & 0.011 \\
\hline \multirow[t]{6}{*}{ Mercury, total recoverable (TRHg) } & \multirow[t]{6}{*}{$\mu \mathrm{g} \cdot \mathrm{L}^{-1}$} & $\mathrm{~N}$ & 151 & 150 & 77 \\
\hline & & Mean & 0.032 & 0.009 & 0.006 \\
\hline & & Median & 0.012 & 0.008 & 0.004 \\
\hline & & SD & 0.067 & 0.010 & 0.006 \\
\hline & & Minimum & ND & ND & ND \\
\hline & & Maximum & 0.497 & 0.103 & 0.032 \\
\hline \multirow[t]{6}{*}{ Dissolved oxygen (DO) } & \multirow[t]{6}{*}{ Milligram per liter $\left(\mathrm{mg} \cdot \mathrm{L}^{-1}\right)$} & $\mathrm{N}$ & 141 & 139 & 72 \\
\hline & & Mean & 8.3 & 4.1 & 8.1 \\
\hline & & Median & 8.5 & 2.6 & 8.2 \\
\hline & & SD & 2.4 & 4.1 & 2.2 \\
\hline & & Minimum & 0.3 & 0.1 & 0.1 \\
\hline & & Maximum & 13.3 & 12.6 & 12.9 \\
\hline \multirow[t]{6}{*}{$\mathrm{pH}$} & \multirow[t]{6}{*}{ Standard units } & $\mathrm{N}$ & 141 & 140 & 73 \\
\hline & & Mean & 7.4 & 6.9 & 6.9 \\
\hline & & Median & 7.3 & 6.9 & 6.9 \\
\hline & & SD & 0.6 & 0.4 & 0.3 \\
\hline & & Minimum & 6.4 & 5.7 & 6.2 \\
\hline & & Maximum & 9.1 & 8.1 & 7.8 \\
\hline \multirow[t]{6}{*}{ Specific conductance (SC) } & \multirow{6}{*}{$\begin{array}{l}\text { Microsiemens per centimeter } \\
\text { at } 25 \text { degrees Celsius } \\
\left(\mu \mathrm{S} \cdot \mathrm{cm}^{-1} \text { at } 25^{\circ} \mathrm{C}\right)\end{array}$} & $\mathrm{N}$ & 151 & 150 & 77 \\
\hline & & Mean & 125 & 147 & 129 \\
\hline & & Median & 105 & 138 & 102 \\
\hline & & SD & 64 & 74 & 90 \\
\hline & & Minimum & 43 & 48 & 31 \\
\hline & & Maximum & 389 & 506 & 500 \\
\hline \multirow[t]{6}{*}{ Sulfate $\left(\mathrm{SO}_{4}{ }^{2-}\right)$} & \multirow[t]{6}{*}{$\mathrm{mg} \cdot \mathrm{L}^{-1}$} & $\mathrm{~N}$ & 151 & 150 & 77 \\
\hline & & Mean & 10.9 & 9.9 & 9.6 \\
\hline & & Median & 7.9 & 7.6 & 6.1 \\
\hline & & SD & 7.0 & 8.1 & 11.3 \\
\hline & & Minimum & 2.7 & 0.1 & 0.8 \\
\hline & & Maximum & 34.3 & 50.1 & 67.4 \\
\hline
\end{tabular}


Table 5. Summary statistics for concentrations of mercury and ancillary constituents in water samples.—Continued

[Randomly generated concentration values between 0 and the method detection level (MDL, 0.005 microgram per liter $\left[\mu \mathrm{g} \cdot \mathrm{L}^{-1}\right]$ ) were substituted for nondetections in computations. Abbreviations: N, number of samples collected; SD, standard deviation; ND, not detected; NC, data for constituent was not collected; NA, not applicable; <, less than]

\begin{tabular}{|c|c|c|c|c|c|}
\hline \multirow{2}{*}{ Constituent } & \multirow{2}{*}{ Unit } & \multirow{2}{*}{ Statistic } & \multicolumn{2}{|c|}{ Reservoir } & \multirow{2}{*}{ Stream } \\
\hline & & & Surface & Bottom & \\
\hline \multicolumn{6}{|c|}{ Water-Continued } \\
\hline \multirow[t]{6}{*}{ Chlorophyll $a$ (Chloro $a)$} & \multirow[t]{6}{*}{$\mu \mathrm{g} \cdot \mathrm{L}^{-1}$} & $\mathrm{~N}$ & 147 & $\mathrm{NC}$ & $\mathrm{NC}$ \\
\hline & & Mean & 25.1 & $\mathrm{NC}$ & $\mathrm{NC}$ \\
\hline & & Median & 22.7 & $\mathrm{NC}$ & $\mathrm{NC}$ \\
\hline & & SD & 17.4 & $\mathrm{NC}$ & $\mathrm{NC}$ \\
\hline & & Minimum & 1.9 & $\mathrm{NC}$ & $\mathrm{NC}$ \\
\hline & & Maximum & 96.0 & $\mathrm{NC}$ & $\mathrm{NC}$ \\
\hline \multirow[t]{6}{*}{ Pheophytin $a$ (Pheo $a)$} & \multirow[t]{6}{*}{$\mu \mathrm{g} \cdot \mathrm{L}^{-1}$} & $\mathrm{~N}$ & 147 & $\mathrm{NC}$ & $\mathrm{NC}$ \\
\hline & & Mean & 11.4 & $\mathrm{NC}$ & $\mathrm{NC}$ \\
\hline & & Median & 9.3 & $\mathrm{NC}$ & $\mathrm{NC}$ \\
\hline & & SD & 8.4 & $\mathrm{NC}$ & $\mathrm{NC}$ \\
\hline & & Minimum & 1 & $\mathrm{NC}$ & $\mathrm{NC}$ \\
\hline & & Maximum & 49.4 & $\mathrm{NC}$ & $\mathrm{NC}$ \\
\hline \multirow{6}{*}{$\begin{array}{l}\text { Organic carbon, filterable } \\
\text { (dissolved, DOC) }\end{array}$} & \multirow[t]{6}{*}{$\mathrm{mg} \cdot \mathrm{L}^{-1}$} & $\mathrm{~N}$ & 150 & 149 & 77 \\
\hline & & Mean & 7.16 & 7.77 & 7.63 \\
\hline & & Median & 7.00 & 7.57 & 6.94 \\
\hline & & SD & 1.20 & 1.73 & 3.20 \\
\hline & & Minimum & 4.84 & 4.71 & 2.49 \\
\hline & & Maximum & 11.00 & 16.80 & 18.40 \\
\hline \multirow{6}{*}{$\begin{array}{l}\text { Organic carbon, filterable (total, } \\
\left.\text { TOC }_{\text {water }}\right)\end{array}$} & \multirow[t]{6}{*}{$\mathrm{mg} \cdot \mathrm{L}^{-1}$} & $\mathrm{~N}$ & 151 & $\mathrm{NC}$ & 68 \\
\hline & & Mean & 9.6 & $\mathrm{NC}$ & 9.5 \\
\hline & & Median & 9.5 & $\mathrm{NC}$ & 8.3 \\
\hline & & SD & 1.6 & $\mathrm{NC}$ & 4.7 \\
\hline & & Minimum & 6.2 & $\mathrm{NC}$ & 3.1 \\
\hline & & Maximum & 15.3 & $\mathrm{NC}$ & 26.8 \\
\hline \multirow{6}{*}{$\begin{array}{l}\text { Suspended-sediment concentration } \\
\quad \text { (SSC) }\end{array}$} & \multirow[t]{6}{*}{$\mathrm{mg} \cdot \mathrm{L}^{-1}$} & $\mathrm{~N}$ & $\mathrm{NC}$ & $\mathrm{NC}$ & 66 \\
\hline & & Mean & $\mathrm{NC}$ & $\mathrm{NC}$ & 52 \\
\hline & & Median & $\mathrm{NC}$ & $\mathrm{NC}$ & 12 \\
\hline & & SD & $\mathrm{NC}$ & $\mathrm{NC}$ & 93 \\
\hline & & Minimum & $\mathrm{NC}$ & $\mathrm{NC}$ & 1 \\
\hline & & Maximum & $\mathrm{NC}$ & $\mathrm{NC}$ & 419 \\
\hline \multicolumn{6}{|c|}{ Bed sediment } \\
\hline \multirow{6}{*}{$\begin{array}{l}\text { Mercury, total digestion }(\mathrm{THg}) \\
\quad \text { [bulk-calculated] }\end{array}$} & \multirow{6}{*}{$\begin{array}{l}\text { Milligram per kilogram } \\
\quad\left(\mathrm{mg} \cdot \mathrm{kg}^{-1}\right)\end{array}$} & $\mathrm{N}$ & NA & 15 & 13 \\
\hline & & Mean & NA & $0.07(0.06)$ & $0.11(0.04)$ \\
\hline & & Median & NA & $0.07(0.07)$ & $0.05(<0.01)$ \\
\hline & & SD & NA & $0.03(0.03)$ & $0.21(0.11)$ \\
\hline & & Minimum & NA & $0.02(0.02)$ & $0.02(<0.01)$ \\
\hline & & Maximum & NA & $0.13(0.13)$ & $0.82(0.39)$ \\
\hline
\end{tabular}


Table 5. Summary statistics for concentrations of mercury and ancillary constituents in water samples.-Continued

[Randomly generated concentration values between 0 and the method detection level (MDL, 0.005 microgram per liter $\left[\mu \mathrm{g} \cdot \mathrm{L}^{-1}\right]$ ) were substituted for nondetections in computations. Abbreviations: N, number of samples collected; SD, standard deviation; ND, not detected; NC, data for constituent was not collected; NA, not applicable; <, less than]

\begin{tabular}{|c|c|c|c|c|c|}
\hline \multirow{2}{*}{ Constituent } & \multirow{2}{*}{ Unit } & \multirow{2}{*}{ Statistic } & \multicolumn{2}{|c|}{ Reservoir } & \multirow{2}{*}{ Stream } \\
\hline & & & Surface & Bottom & \\
\hline \multicolumn{6}{|c|}{ Bed sediment-Continued } \\
\hline \multirow[t]{6}{*}{ Organic carbon, total $\left(\mathrm{TOC}_{\mathrm{sed}}\right)$} & Percent $(\%)$ & $\mathrm{N}$ & NA & 15 & 13 \\
\hline & & Mean & NA & 2.79 & 1.47 \\
\hline & & Median & NA & 2.70 & 1.30 \\
\hline & & SD & NA & 0.89 & 0.63 \\
\hline & & Minimum & NA & 1.60 & 0.20 \\
\hline & & Maximum & NA & 4.10 & 2.20 \\
\hline
\end{tabular}

\section{Quality-Assurance and Quality-Control Results}

\section{Contamination in Blanks}

FHg was detected in one field blank and one vehicle blank (water intended to be free of analytes of interest that is used to demonstrate that sample-handling and transport have not introduced contamination) at concentrations below the MRL of $0.010 \mu \mathrm{g} \cdot \mathrm{L}^{-1}$ (Fitzgerald, 2020). FHg was either not detected or detected at concentrations below the MRL in water samples collected on the date associated with the vehicle blank. The FHg concentration in the one water sample that was collected from stream site 22 in association with the field blank from February 8, 2008 was above the MRL but did not exceed the NCWQC for mercury. Because $\mathrm{FHg}$ was not detected in any of the other nine samples from site 22 , any contamination present in the sample collected on February 8, 2008, would not affect the overall median value for stream site 22 .

TRHg was also detected in a vehicle blank at a level below the MRL. TRHg concentrations in two of the six environmental water samples collected on the date when the vehicle blank was contaminated were greater than the NCWQC and thus raised the possibility that contamination may have caused these environmental samples to be miscategorized as exceedances. Intermittent high variability in sample replicates for TRHg concentrations (described below) also indicated that error in TRHg concentration estimates for environmental samples was likely not uncommon over the course of the study. For a conservative estimate of the number of samples that tested above the NCWQC for mercury, the frequencies of FHg concentrations (which did not appear to have precision issues similar to those for TRHg) exceeding the NCWQC were used for comparison with the frequencies of TRHg exceedances. Frequent DOC contamination was detected in 9 of 11 field blanks (Fitzgerald, 2020). Levels of DOC detected in these blanks $\left(1.1 \mathrm{mg} \cdot \mathrm{L}^{-1}\right.$ maximum) were all lower than the minimum DOC concentration in environmental samples $\left(2.5 \mathrm{mg} \cdot \mathrm{L}^{-1}\right.$ and $4.7 \mathrm{mg} \cdot \mathrm{L}^{-1}$ in stream and reservoir samples, respectively).

\section{Bias}

The USGS Quality Systems Branch Inorganic Blind Sample Project noted a moderate negative bias in FHg concentrations of about 12 to 13 percent and about 6.2 to 12 percent for TRHg from July 2007 through approximately February 2008 (USGS, undated $b$ ). For environmental samples, the mean and median of FHg concentrations above the MRL were lower between July 2007 and February 2008 than between March 2008 and June 2009; however, the proportion of FHg values above the MRL was higher during the earlier period. Under the assumption that the negative bias affected samples collected from all sites during this period, the potential consequences included lower seasonal median concentrations for summer, fall, and winter surface samples from reservoir sites (for which there were significant differences in seasonal median values, described below), and lower overall median concentrations for stream sites and bottom samples from reservoir sites (for which there were no significant differences in seasonal median values, described below). In surface samples from reservoir sites, differences in mercury detections, NCWQC exceedances, or concentrations between spring and other seasons would likely be more pronounced than indicated by the data. Additionally, the frequency of detections and NCWQC exceedances may have been greater for samples collected during this period than indicated by the data with negative bias. If the negative bias resulted in more non-detections for FHg or TRHg, less precision in the concentration estimates for the data could reduce the probability of detecting associations between mercury and predictor variables. No systematic differences were observed between known and measured concentrations of $\mathrm{THg}$ or $\mathrm{TOC}_{\text {sed }}$ in bed sediment (appendix 2). 


\section{Precision}

All RPDs for $\mathrm{FHg}, \mathrm{SO}_{4}{ }^{2-}, \mathrm{TOC}_{\text {water }}$, and $\mathrm{DOC}$ were below 25 percent (appendix 3). Chloro $a$ had two replicate sets with an RSD or RPD greater than 25 percent (32 and 34 percent) (Fitzgerald, 2020). One of these sets had an absolute difference of 1.0, which is low relative to all of the Chloro $a$ concentrations measured in the environmental samples (median: $22.3 \mu \mathrm{g} \cdot \mathrm{L}^{-1}$, max: $96 \mu \mathrm{g} \cdot \mathrm{L}^{-1}$ ) (Fitzgerald, 2020). The other had an absolute difference of $12.1 \mu \mathrm{g} \cdot \mathrm{L}^{-1}$ (Fitzgerald, 2020). Errors in the measurements of physical or chemical waterquality parameters in environmental samples could obscure any existing correlative relationship with mercury concentrations. One replicate SSC set had an RPD of 40 percent; however, this set's low absolute difference $\left(2 \mathrm{mg} \cdot \mathrm{L}^{-1}\right)$ relative to concentrations measured in other environmental samples (median: $12 \mathrm{mg} \cdot \mathrm{L}^{-1}$, max: $419 \mathrm{mg} \cdot \mathrm{L}^{-1}$ ) indicated that these differences were unlikely to affect results of statistical analyses (Fitzgerald, 2020).

Nearly one-third of TRHg replicate sets (4 of 13) had RPDs greater than 25 percent (Fitzgerald, 2020); 3 of these had absolute differences greater than the NCWQC for mercury. All replicate sets with RPDs greater than 25 percent were from reservoir sites; however, only 3 of the 13 replicate sets were collected from stream sites. Of the replicate sets with TRHg RPDs greater than 25 percent, absolute concentration differences ranged from $0.008 \mu \mathrm{g} \cdot \mathrm{L}^{-1}$ to $0.032 \mu \mathrm{g} \cdot \mathrm{L}^{-1}$, and RPDs ranged from 67 to 145 percent (appendix 3). More than 90 percent of the environmental water samples had TRHg concentrations below the maximum absolute difference of $0.032 \mu \mathrm{g} \cdot \mathrm{L}^{-1}$ in replicate samples. Although they were not measured in reservoir-water samples in this study, turbidity and suspended sediment can cause high variability in TRHg measurements; for this reason, occasional high variability in TRHg concentrations in this study was not unexpected. The frequency of absolute differences greater than the NCWQC of $0.012 \mu \mathrm{g} \cdot \mathrm{L}^{-1}$ among the replicate sets, however, indicates that caution is needed when TRHg results are interpreted. Furthermore, of the environmental water samples in which FHg was above the MRL, five exhibited higher concentrations of FHg than TRHg (USGS, 2016b), indicating a known low frequency of error in estimates of mercury concentrations in environmental water samples. One consequence of error in measured mercury concentrations is the potential for obscuring associations with ancillary constituents, antecedent precipitation, or land-use variables. Therefore, the lack of a statistically significant association between FHg or TRHg and a given predictor variables does not preclude an ecologically relevant association.

With regard to TRHg exceedances of the NCWQC in environmental samples, differences in TRHg concentration measurements greater than the NCWQC itself for nearly one in three replicate sets indicates that the frequency of exceedances reported herein should be regarded as a general (not absolute) estimate. Measurement precision in replicate samples was better for FHg, which is a component of TRHg. The frequency of FHg concentrations greater than $0.012 \mu \mathrm{g} \cdot \mathrm{L}^{-1}$ was used as a conservative estimate of TRHg exceedances of the NCWQC for mercury, because samples with FHg concentrations less than $0.012 \mu \mathrm{g} \cdot \mathrm{L}^{-1}$ may have had TRHg concentrations greater than or equal to $0.012 \mu \mathrm{g} \cdot \mathrm{L}^{-1}$.

One of two field-replicate sets showed a high degree of variation in bed sediment $\mathrm{THg}$ concentration $\left(0.03 \mathrm{mg} \cdot \mathrm{kg}^{-1}\right.$ and $0.10 \mathrm{mg} \cdot \mathrm{kg}^{-1}$ ) (Fitzgerald, 2020). This variation could be caused by analytical variation, sample heterogeneity, or smallscale variability in bed sediment THg concentrations at that site. Field and laboratory replicates for $\mathrm{TOC}_{\text {sed }}$ were in acceptable agreement (Fitzgerald, 2020).

\section{Water-Sample Mercury Detections, Concentrations, and Exceedances}

FHg was detected in 109 reservoir-water samples (36 percent; table 6, fig. 2), and TRHg was detected in 183 reservoir-water samples (61 percent; table 6, fig. 2). Both FHg and TRHg were detected in at least two samples from each reservoir site (fig. 2). Mercury was detected more often in samples collected from the surface of the water column in reservoirs versus the bottom, with FHg and TRHg detections in at least one surface sample from all sites, and at least one bottom sample from all but two reservoir sites (table 6, fig. 2). For stream sites, FHg was detected in 9 and TRHg in 24 of 77 water samples (12 percent and 31 percent, respectively; table 6, fig. 3), with at least $1 \mathrm{FHg}$ detection at 7 sites and at least 1 TRHg detection at 12 of 14 stream sites (table 6, fig. 3). The maximum mercury concentrations detected in water samples were $0.099 \mu \mathrm{g} \cdot \mathrm{L}^{-1} \mathrm{FHg}$ and $0.497 \mu \mathrm{g} \cdot \mathrm{L}^{-1} \mathrm{TRHg}$, both in the same reservoir-surface sample from site 27 (table 5, figs. 4, 5). FHg concentrations in streams were comparatively low, with only one sample at a concentration greater than the MRL $\left(0.011 \mu \mathrm{g} \cdot \mathrm{L}^{-1}\right.$ at site 22 ; table 5 , fig. 6$)$. The maximum TRHg concentration detected in stream-water samples was $0.032 \mu \mathrm{g} \cdot \mathrm{L}^{-1}$ from site 9 (table 5, fig. 6).

FHg and TRHg exceeded the NCWQC for mercury more often in reservoir-surface samples ( 25 percent and 50 percent, respectively; table 6 , fig. 2) compared to reservoir-bottom samples (7 percent and 26 percent, respectively; table 6 , fig. 2). The two reservoir sites with the highest frequency of FHg concentrations in surface samples exceeding the NCWQC for mercury were sites in Falls Lake and Jordan Lake (reservoir sites 12 and 28, respectively; fig. 7). No stream samples had concentrations of FHg that exceeded the NCWQC for mercury (table 6, fig. 7). In contrast, TRHg concentrations exceeded the NCWQC for mercury in eight stream-water samples (10 percent; table 6, fig. 3 ); the excess was spread among several sites without a clear spatial pattern (fig. 8). TRHg concentrations exceeded the NCWQC in 114 reservoir-water samples (38 percent; table 6, fig. 2), with the highest frequencies of exceedances in reservoirsurface samples generally concentrated around Jordan Lake and Falls Lake (fig. 8). 
Table 6. Number of water samples and sites with mercury-concentration detections and exceedances.

[Number of reservoir and stream-water samples and number of study sites with filtered mercury (FHg) and total recoverable mercury (TRHg) detections (method detection level $=0.005$ microgram per liter $\left[\mu \mathrm{g} \cdot \mathrm{L}^{-1}\right]$ ) and concentrations that exceeded the North Carolina water-quality criterion for mercury of $0.012 \mu \mathrm{g} \cdot \mathrm{L}^{-1}$. The total numbers of samples or sites for the category are noted in parentheses]

\begin{tabular}{|c|c|c|c|c|c|c|c|}
\hline \multirow{2}{*}{$\begin{array}{c}\text { Mercury } \\
\text { constituent }\end{array}$} & \multirow[b]{2}{*}{ Unit } & \multicolumn{3}{|c|}{ Number of detections } & \multicolumn{3}{|c|}{ Number of exceedances } \\
\hline & & $\begin{array}{l}\text { Reservoir } \\
\text { surface }\end{array}$ & $\begin{array}{c}\text { Reservoir } \\
\text { bottom }\end{array}$ & Stream & $\begin{array}{l}\text { Reservoir } \\
\text { surface }\end{array}$ & $\begin{array}{c}\text { Reservoir } \\
\text { bottom }\end{array}$ & Stream \\
\hline $\mathrm{FHg}$ & Sites & $15(15)$ & $13(15)$ & $7(14)$ & $13(15)$ & $8(15)$ & $0(14)$ \\
\hline $\mathrm{TRHg}$ & Samples & $95(151)$ & $88(150)$ & $24(77)$ & $76(151)$ & $38(150)$ & $8(77)$ \\
\hline
\end{tabular}

\section{A. Filtered mercury}

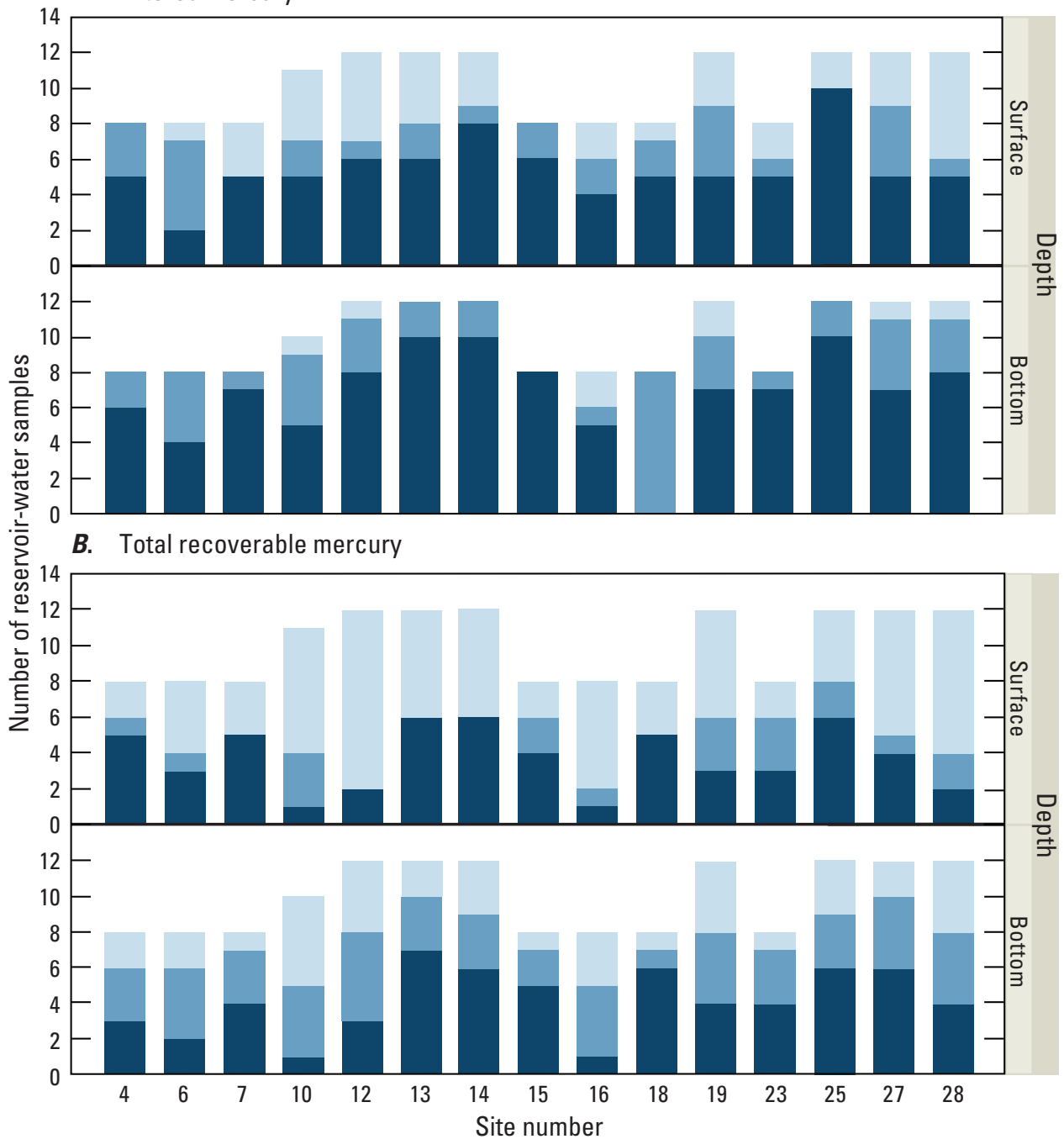

\section{EXPLANATION}

Exceedance (concentration $\geq 0.012$ microgram per liter)

Detection (concentration $\geq \mathbf{0 . 0 0 5}$ and $<0.012$ microgram per liter)

Figure 2. Graphs showing number of reservoir-water samples by sample site and depth with $A$, filtered mercury and $B$, total recoverable mercury detections and concentrations that exceeded the North Carolina water-quality criterion for total mercury. 
A. Filtered mercury

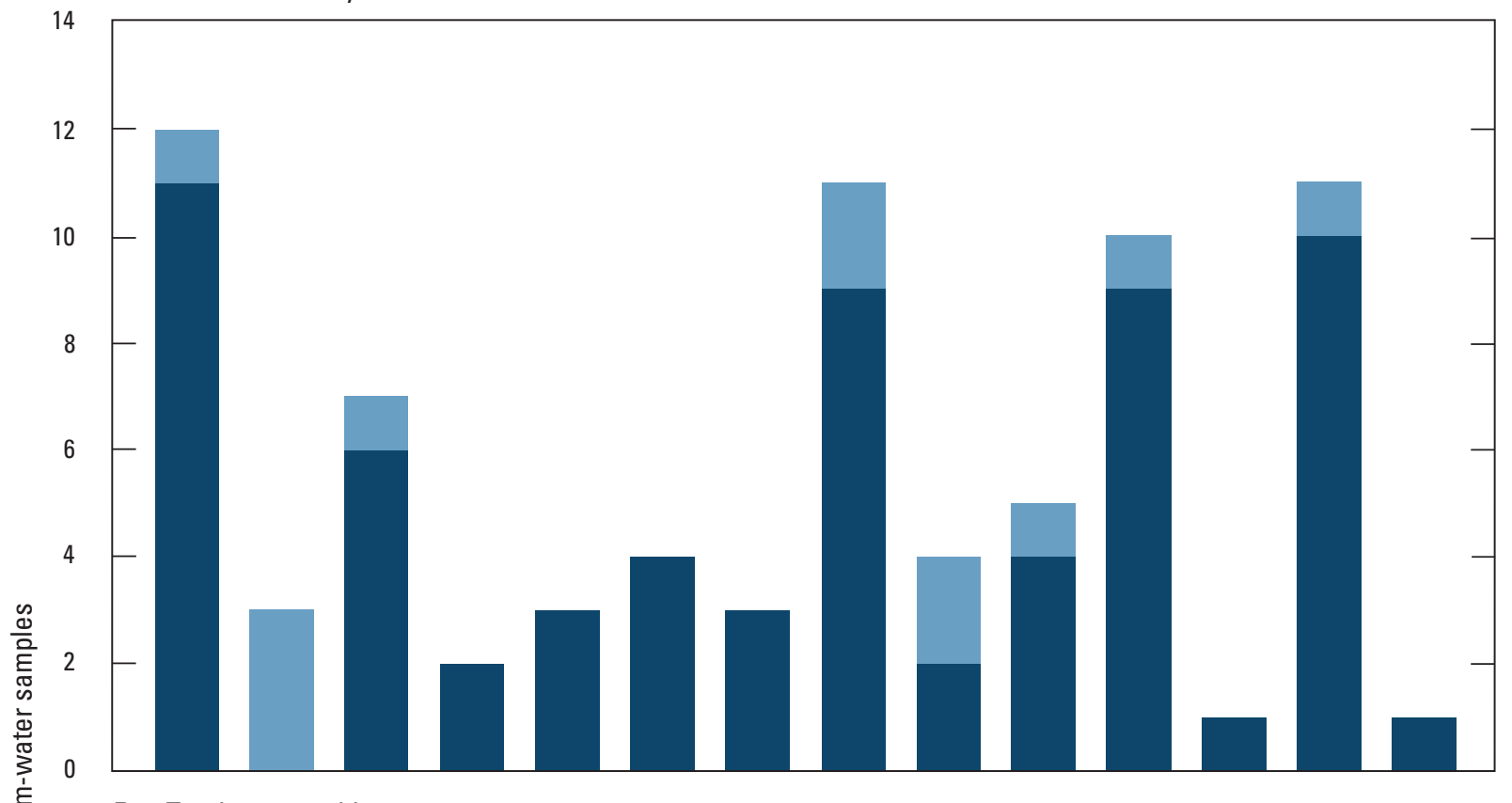

B. Total recoverable mercury

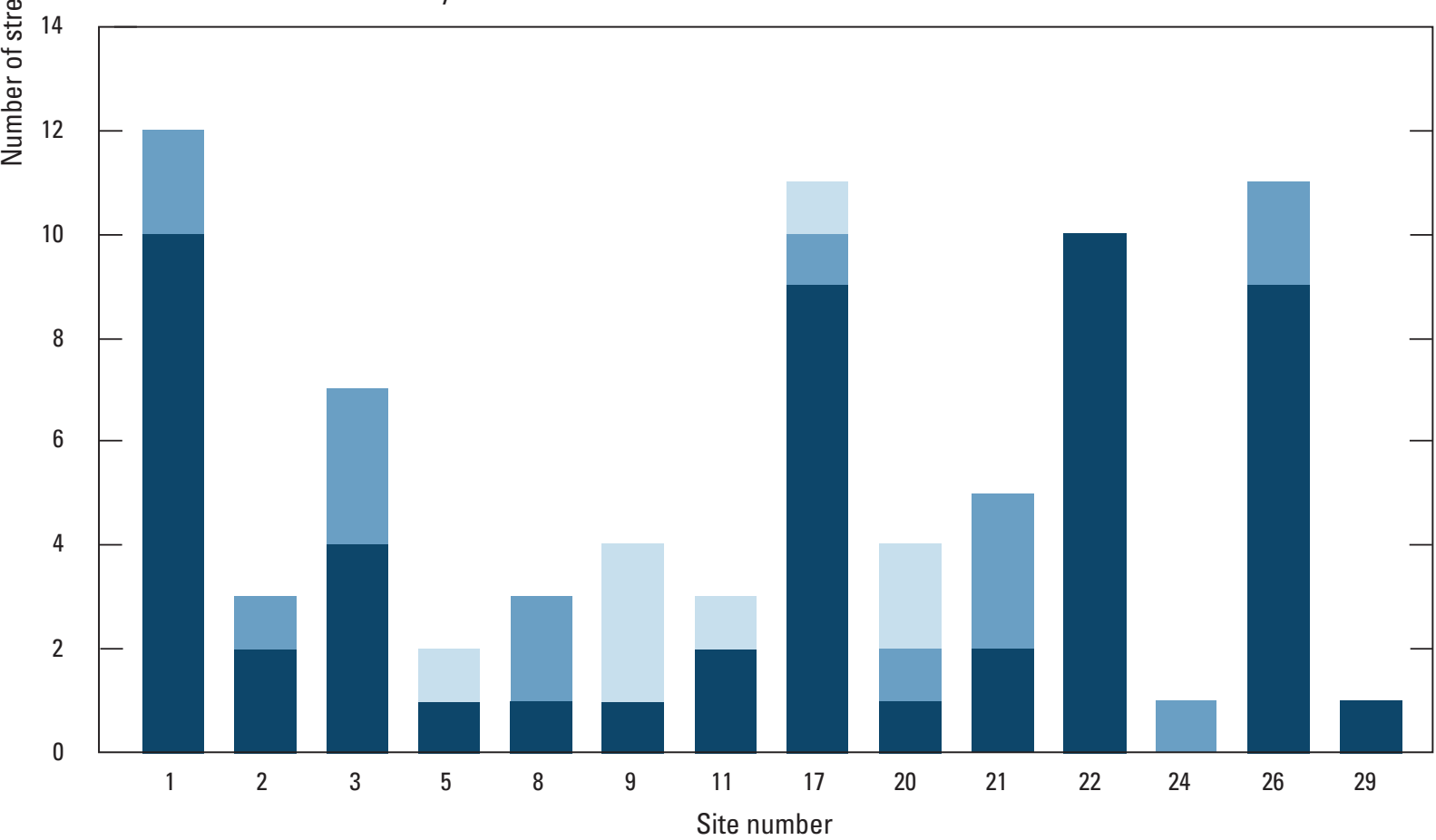

EXPLANATION

Exceedance (concentration $\geq 0.012$ microgram per liter)

Detection (concentration $\geq 0.005$ and $<0.012$ microgram per liter)

Non-detection

Figure 3. Graphs showing number of stream-water samples by sample site with $A$, filtered mercury and $B$, total recoverable mercury detections and concentrations that exceeded the North Carolina water-quality criterion for total mercury. 


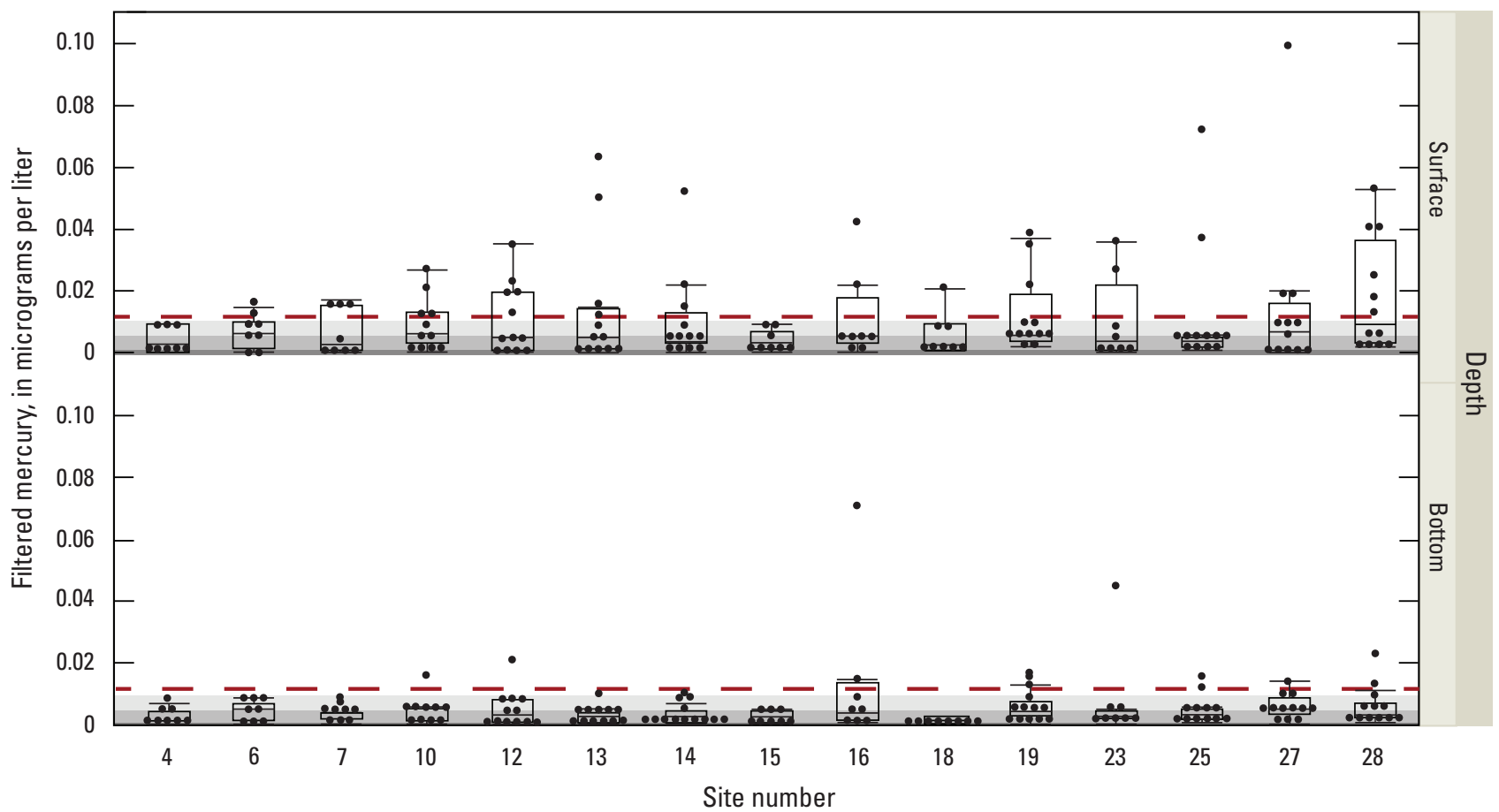

\section{EXPLANATION}

- Concentration of single sample

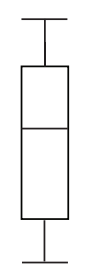

90th percentile

75th percentile

50th percentile (median)

25th percentile

10th percentile
- - - North Carolina water-quality criteron (0.012 microgram per liter)

Measured concentrations below MRL

Randomly generated concentrations below MDL

Figure 4. Boxplot showing filtered mercury concentrations in reservoir-water samples, by sample site and depth. Randomly generated values between 0 and $0.005 \mu \mathrm{g} \cdot \mathrm{L}^{-1}$ were substituted for non-detections. Boxplots show the median and interquartile range (IOR), with whiskers extending to $1.5 \times$ IQR from the first and third quantiles. $\mu \mathrm{g} \cdot \mathrm{L}^{-1}$, microgram per liter; MRL, method reporting level; MDL, method detection level. 


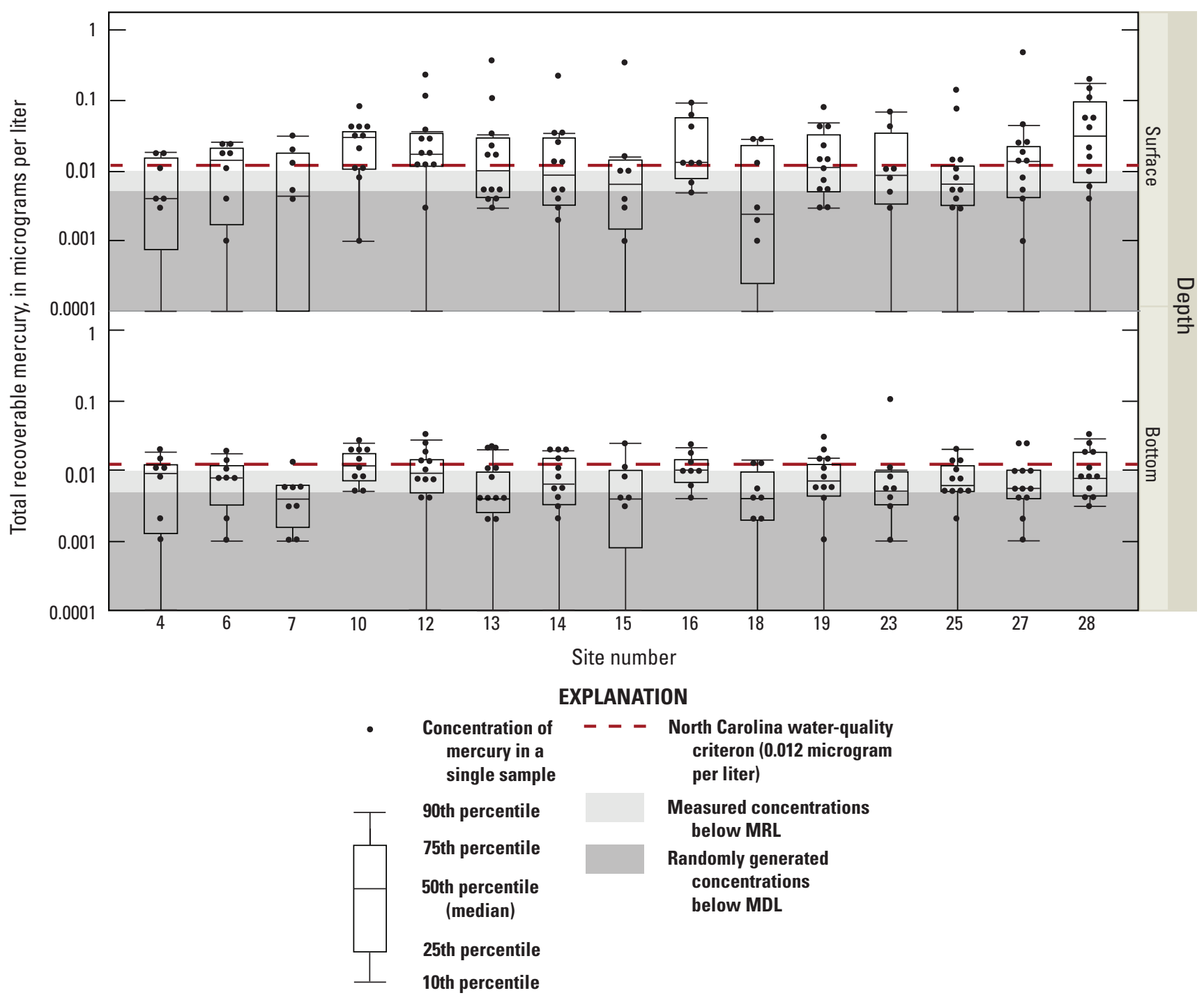

Figure 5. Boxplot showing total recovered mercury concentrations on log scale in reservoir-water samples, by sample site and depth. Randomly generated values between 0 and $0.005 \mu \mathrm{g} \cdot \mathrm{L}^{-1}$ were substituted for non-detections. Generated values of 0 are not shown on log scale. Boxplots show the mean and interquartile range (IOR), with whiskers extending to $1.5 \times \operatorname{IQR}$ from the first and third quantiles. $\mu \mathrm{g} \cdot \mathrm{L}^{-1}$, microgram per liter; MRL, method reporting level; MDL, method detection level. 
A. Filtered mercury
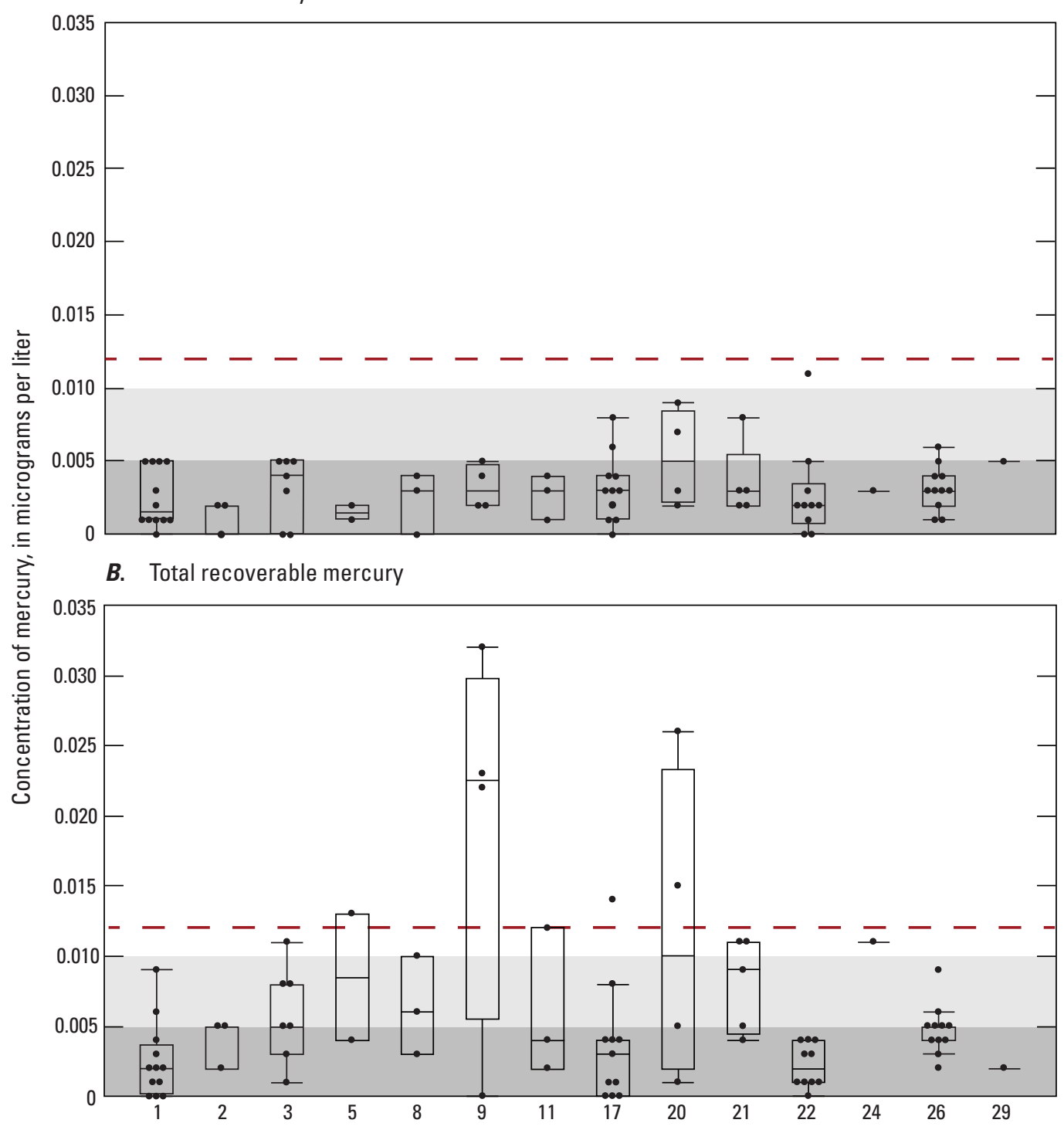

Site number

\section{EXPLANATION}

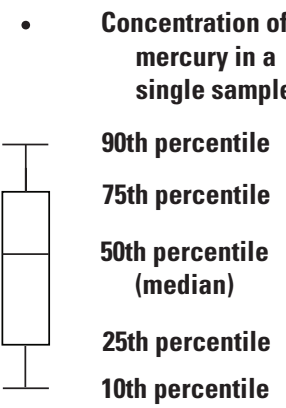

Figure 6. Boxplots showing $A$, filtered mercury, and $B$, total recoverable mercury concentrations in stream-water samples, by sample site. Randomly generated values between 0 and $0.005 \mu \mathrm{g} \cdot \mathrm{L}^{-1}$ were substituted for non-detections. Boxplots show the mean and interquartile range (IOR), with whiskers extending to $1.5 \times \mathrm{IQR}$ from the first and third quantiles. $\mu \mathrm{g} \cdot \mathrm{L}^{-1}$, microgram per liter; $\mathrm{MRL}$, method reporting level; MDL, method detection level. 


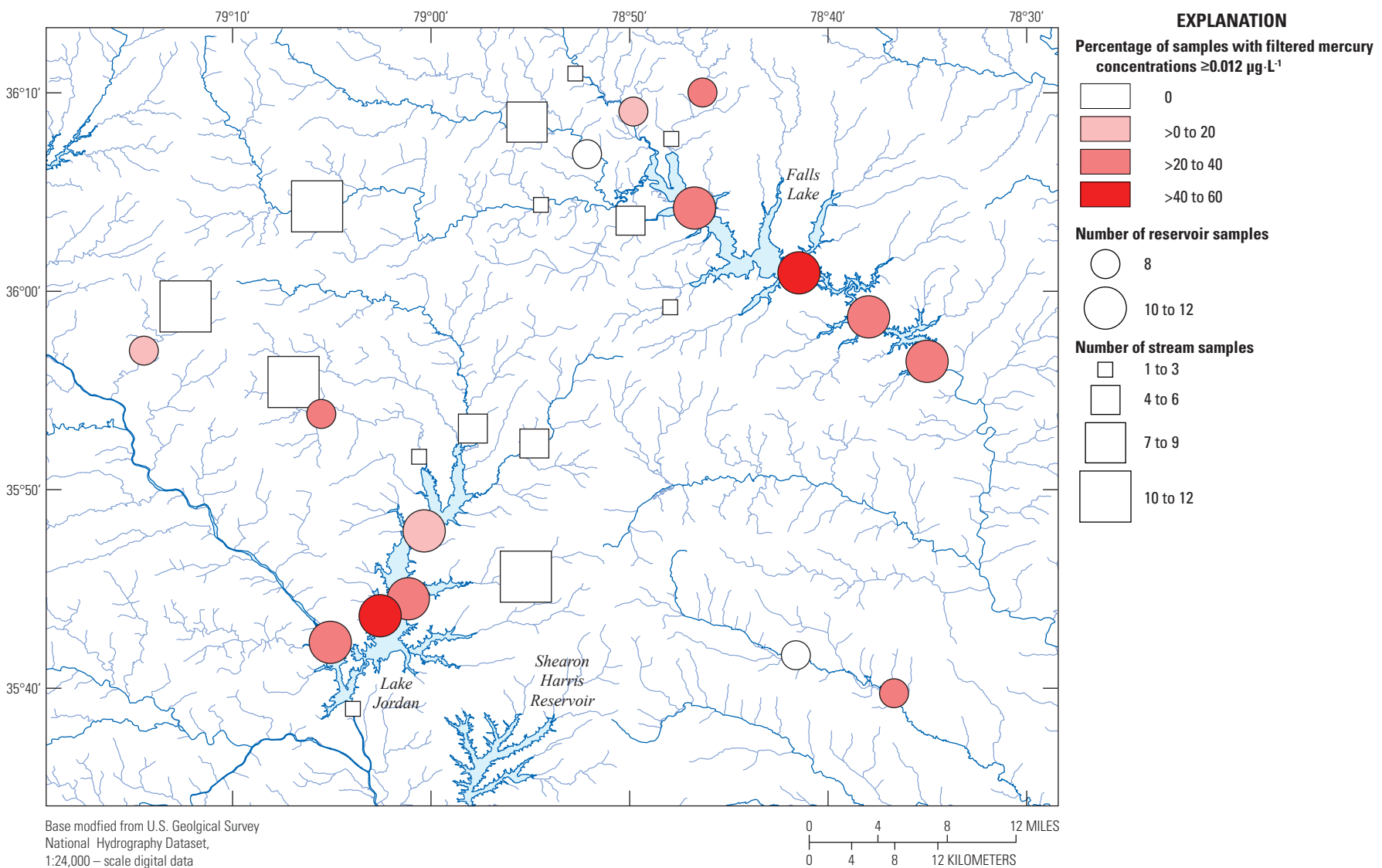

Figure 7. Map showing percentages of reservoir-surface and stream-water samples with filtered mercury concentrations exceeding the North Carolina water-quality criterion for total mercury $\left(\geq 0.012 \mu \mathrm{g} \cdot \mathrm{L}^{-1}\right) . \mu \mathrm{g} \cdot \mathrm{L}^{-1}$, microgram per liter. 


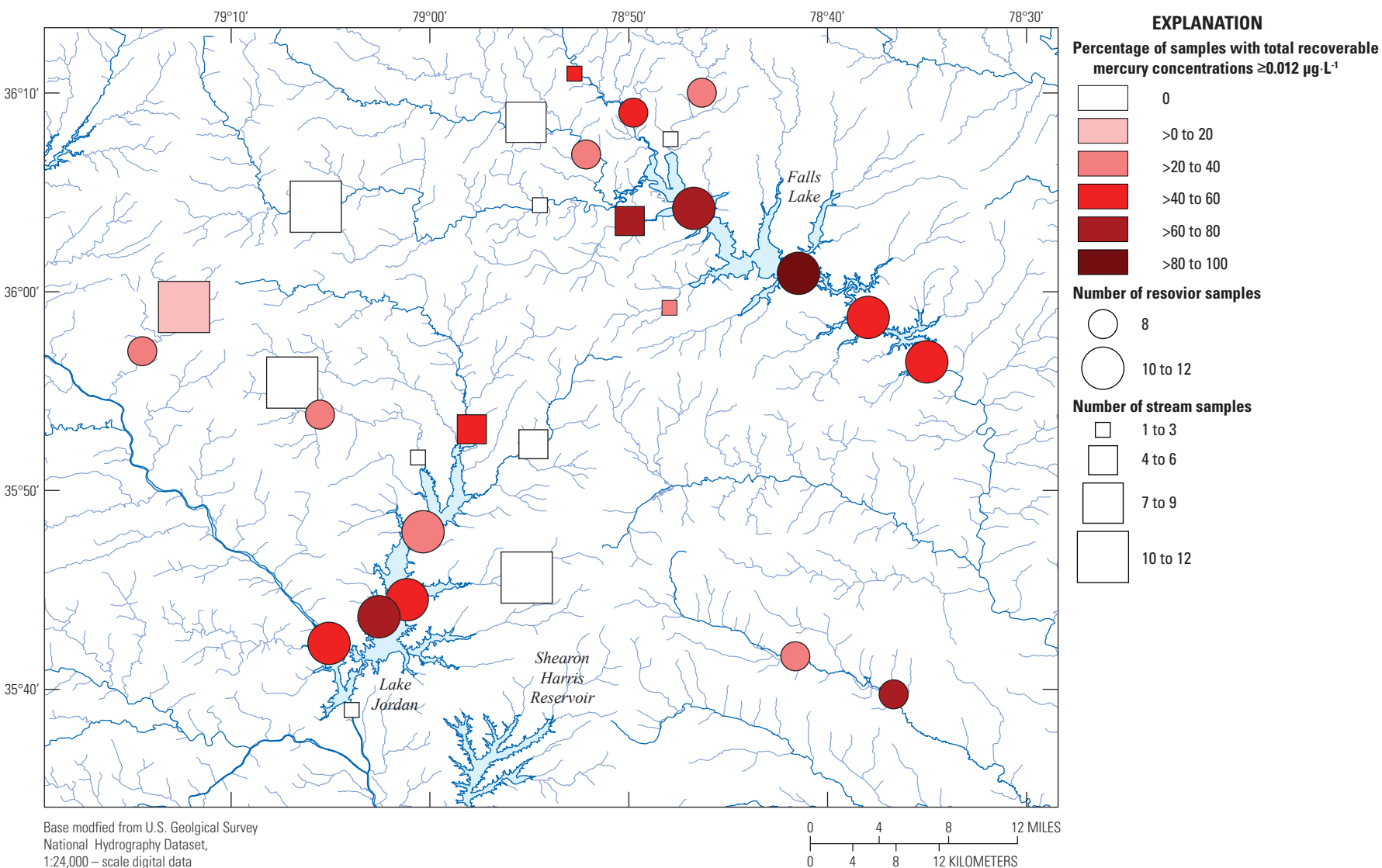

Figure 8. Map showing percentages of reservoir-surface and stream-water samples with total recoverable mercury concentrations exceeding the North Carolina water-quality criterion for total mercury $\left(\geq 0.012 \mu \mathrm{g} \cdot \mathrm{L}^{-1}\right) . \mu \mathrm{g} \cdot \mathrm{L}^{-1}$, microgram per liter.

\section{Seasonal Variation of Mercury Concentrations in Water Samples}

Correlations between reservoir-surface and reservoirbottom mercury concentrations were significant for every season except for winter TRHg concentrations (table 7), suggesting that seasonal lake stratification was not common in the reservoir sites. The correlations between reservoir-surface and reservoirbottom mercury concentrations were not particularly strong in some cases (for example, $\rho=0.502$ between surface and bottom TRHg concentrations in the spring season) and thus suggested that the degree of mixing might differ across seasons.

Seasonal patterns of median FHg and TRHg concentrations were different between reservoir surface- and bottom-water samples. Seasonal differences in median FHg concentrations were detected in reservoir surface-water samples $\left(X^{2}=9.108\right.$, $\mathrm{p}=0.028$; fig. 9) and in median TRHg concentrations for reservoir bottom-water samples $\left(X^{2}=12.208, p=0.007\right.$; fig. 10) suggesting that the degree of mixing might have varied among seasons. Median reservoir-surface FHg concentrations and median reservoir-bottom TRHg concentrations were greatest in the summer and fall (fig. 9 and fig. 10, respectively). No significant differences were detected in seasonal median reservoir-bottom FHg $\left(\mathrm{X}^{2}=7.206, \mathrm{p}=0.066\right)$ or reservoirsurface TRHg concentrations $\left(\mathrm{X}^{2}=7.12, \mathrm{p}=0.068\right)$. Stream samples also did not exhibit seasonal patterns in median $\mathrm{FHg}$ or TRHg concentrations $\left(\mathrm{X}^{2}=2.778, \mathrm{p}=0.427 ; \mathrm{X}^{2}=3.654\right.$, $\mathrm{p}=0.301$, respectively). Concentrations of FHg in reservoirsurface samples most frequently exceeded the NCWQC for mercury in the fall followed by the summer (fig. 9, table 8). Seasonal patterns of median TRHg concentrations in reservoir bottom-water samples were similar to median $\mathrm{FHg}$ concentrations in reservoir surface-water samples, with concentrations most frequently exceeding the NCWQC for mercury in the fall followed by the summer (fig. 10, table 8).

Table 7. Spearman correlations ( $\rho$ with $p$-value in parentheses) by season between reservoir-surface and reservoir-bottom mercury concentrations for concurrently collected samples.

[FHg, filtered mercury; TRHg, total recoverable mercury; <, less than]

\begin{tabular}{lll}
\hline \multicolumn{1}{c}{ Season } & \multicolumn{1}{c}{$\mathbf{~}$ FHg } & \multicolumn{1}{c}{ TRHg } \\
\hline Spring & $0.869(<0.001)$ & $0.502(0.015)$ \\
Summer & $0.523(0.001)$ & $0.660(<0.001)$ \\
Fall & $0.622(0.013)$ & $0.668(0.007)$ \\
Winter & $0.591(0.010)$ & $0.140(0.578)$ \\
\hline
\end{tabular}




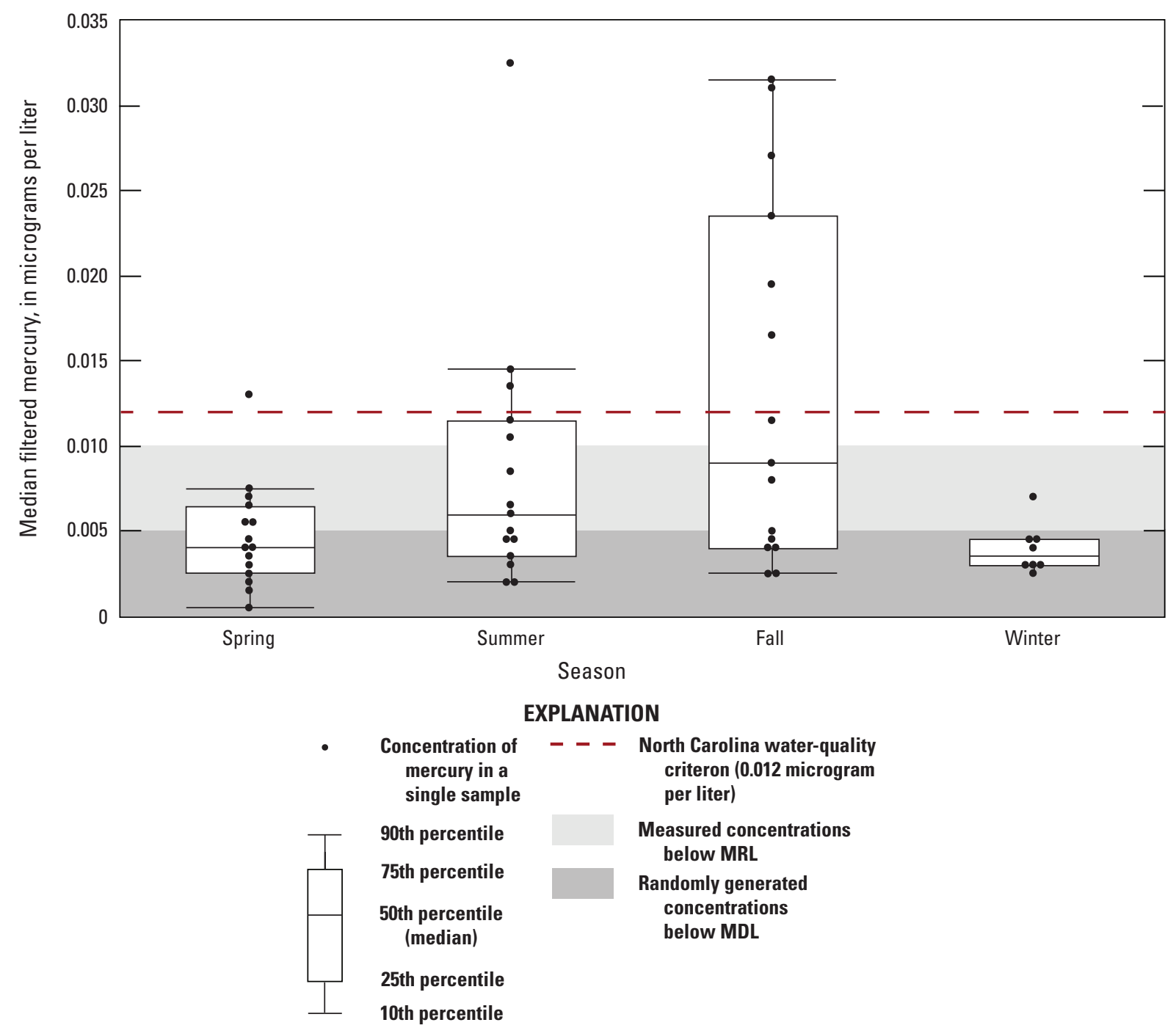

Figure 9. Boxplot showing seasonal median (by site) filtered mercury concentrations for reservoir surface-water samples. Randomly generated values between 0 and $0.005 \mu \mathrm{g} \cdot \mathrm{L}^{-1}$ were substituted for non-detections. Samples were only collected from 8 of the 15 sites during winter. Boxplots show the mean and interquartile range (IOR) with whiskers extending to $1.5 \times$ IQR from the first and third quantiles. MRL, method reporting level; MDL, method detection level; $\mu \mathrm{g} \cdot \mathrm{L}^{-1}$, microgram per liter. 


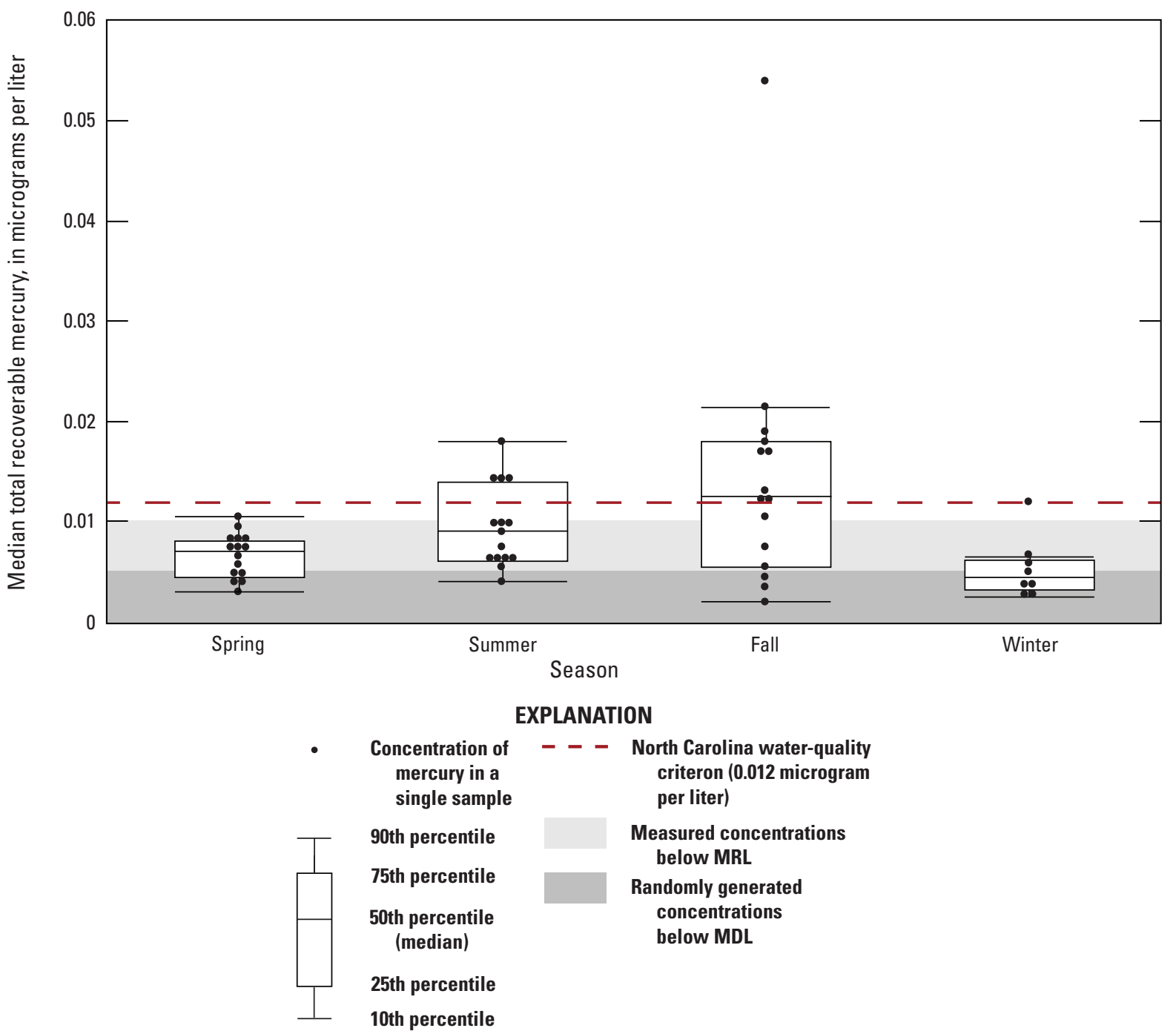

Figure 10. Boxplot showing seasonal median (by site) total recoverable mercury concentrations for reservoir bottom-water samples. Randomly generated values between 0 and $0.005 \mu \mathrm{g} \cdot \mathrm{L}^{-1}$ were substituted for non-detections. Samples were only collected from 8 of the 15 sites during winter. Boxplots show the mean and interquartile range (IQR) with whiskers extending to $1.5 \times$ IQR from the first and third quantiles. MRL, method reporting level; MDL, method detection level; $\mu \mathrm{g} \cdot \mathrm{L}^{-1}$, microgram per liter. 
Table 8. Number and percentage of samples with mercury-concentration detections and exceedances by waterbody type, sample depth, and season.

[Number of reservoir and stream-water samples with filtered mercury (FHg) and total recoverable mercury (TRHg) detections (method detection level $=0.005$ microgram per liter $\left[\mu \mathrm{g} \cdot \mathrm{L}^{-1}\right]$ ) and concentrations that exceeded the North Carolina water-quality criterion for mercury of $0.012 \mu \mathrm{g} \cdot \mathrm{L}^{-1}$. Abbreviations: $\mathrm{N}$, number of samples; \%, percent]

\begin{tabular}{cllccccc}
\hline $\begin{array}{c}\text { Waterbody } \\
\text { type }\end{array}$ & Depth & Season & N & $\begin{array}{c}\text { FHg } \\
\text { detections }\end{array}$ & $\begin{array}{c}\mathbf{F H g} \\
\text { exceedances }\end{array}$ & $\begin{array}{c}\text { TRHg } \\
\text { detections }\end{array}$ & $\begin{array}{c}\text { TRHg } \\
\text { exceedances }\end{array}$ \\
\hline Reservoir & Surface & Spring & 30 & $12(40 \%)$ & $2(7 \%)$ & $21(70 \%)$ & $15(50 \%)$ \\
& & Summer & 60 & $31(52 \%)$ & $20(33 \%)$ & $36(60 \%)$ & $31(52 \%)$ \\
& & Fall & 30 & $17(57 \%)$ & $12(40 \%)$ & $21(70 \%)$ & $19(63 \%)$ \\
& & Winter & 31 & $9(29 \%)$ & $5(16 \%)$ & $17(56 \%)$ & $11(36 \%)$ \\
& Bottom & Spring & 30 & $6(20 \%)$ & $0(0 \%)$ & $18(60 \%)$ & $2(7 \%)$ \\
& & Summer & 60 & $14(23 \%)$ & $4(7 \%)$ & $39(65 \%)$ & $22(37 \%)$ \\
Stream & & Fall & 30 & $12(40 \%)$ & $6(20 \%)$ & $20(67 \%)$ & $12(40 \%)$ \\
& & Winter & 30 & $8(31 \%)$ & $1(3 \%)$ & $11(41 \%)$ & $2(9 \%)$ \\
& Surface of & Spring & 28 & $6(15 \%)$ & $0(0 \%)$ & $11(34 \%)$ & $2(5 \%)$ \\
& the water & Summer & 18 & $1(5 \%)$ & $0(0 \%)$ & $2(15 \%)$ & $0(0 \%)$ \\
& column & Fall & 12 & $1(6 \%)$ & $0(0 \%)$ & $6(56 \%)$ & $5(44 \%)$ \\
& & Winter & 19 & $1(3 \%)$ & $0(0 \%)$ & $5(43 \%)$ & $1(10 \%)$ \\
\hline
\end{tabular}

\section{Bed Sediment}

Mercury was detected in all 28 bed sediment samples, with measured $\mathrm{THg}$ concentrations ranging from 0.02 to $0.82 \mathrm{mg} \cdot \mathrm{kg}^{-1}$ and bulk-calculated THg concentrations ranging from $<0.01$ to $0.39 \mathrm{mg} \cdot \mathrm{kg}^{-1}$ in stream sediment samples (mean $=0.04 \mathrm{mg} \cdot \mathrm{kg}^{-1}$, median $<0.01 \mathrm{mg} \cdot \mathrm{kg}^{-1}$; table 5) and from 0.02 to $0.13 \mathrm{mg} \cdot \mathrm{kg}^{-1}$ in reservoir samples (mean $=0.06 \mathrm{mg} \cdot \mathrm{kg}^{-1}$, median $=0.07 \mathrm{mg} \cdot \mathrm{kg}^{-1}$; table 5, fig. 11). Only one site (site 24 , a stream site) had a bulkcalculated THg concentration of $0.39 \mathrm{mg} \cdot \mathrm{kg}^{-1}$ (table 5) that exceeded the level below which adverse effects to sedimentdwelling organisms were unlikely $\left(0.18 \mathrm{mg} \cdot \mathrm{kg}^{-1}\right)$; however, $0.39 \mathrm{mg} \cdot \mathrm{kg}^{-1}$ is below the $1.06 \mathrm{mg} \cdot \mathrm{kg}^{-1}$ concentration of total mercury in bed sediment that is expected to cause adverse effects to sediment-dwelling organisms (MacDonald and others, 2000). All FHg concentrations in water samples collected simultaneously with the bed sediment samples were below the MRL, and no significant associations were detected between bulk-calculated bed sediment $\mathrm{THg}$ and $\mathrm{FHg}$ for stream-water samples $(\rho=-0.1864, p=0.5421)$, reservoir surface-water samples $(\rho=0.1425, p=0.6125)$, or bottomwater samples $(\rho=0.0705, p=0.8029)$. No significant correlations were detected between bed sediment bulk-calculated THg concentrations and TRHg in stream-water samples ( $\rho=0.4308, p=0.1416)$, reservoir surface-water samples ( $\rho=-0.1978, p=0.4797)$, or reservoir bottom-water samples $(\rho=0.1764, p=0.5294)$.

\section{Ancillary Constituent, Precipitation, and Land-Use Associations with Median Mercury Concentrations in Water and Bed Sediment}

Land-use variables (percentage of drainage area composed of urban development, forest, impervious surface, and wetland; table 1) were all highly correlated among each other for both stream and reservoir sites. The weakest correlation (smallest absolute value of the Spearman $\rho$ ) between land-use types in stream catchments was between forest and wetland areas $(|\rho|=0.670 ; p=0.0087)$. For the 13 reservoir catchments for which drainage-area and land-use percentages could be calculated, the weakest correlation in land-use types was between urban and wetland area $(|\rho|=0.725 ; p=0.005)$. If significant correlations were found between mercury concentrations and multiple land-use variables, this could be an artifact of the significant correlations of the percentages of areas with different land-use types within catchments. The interpretation of land-use associations with mercury concentrations might thus be confounded by the correlations among land-use variables.

The only water-sample mercury constituents that exhibited seasonal patterns in median concentrations and thus were investigated for seasonal associations with potential driver variables were reservoir-surface $\mathrm{FHg}$ concentrations and reservoir-bottom TRHg concentrations. Numerous nondetections of FHg prevented the analysis of reservoir-bottom median FHg and stream median FHg associations, as well as reservoir-surface spring and winter median FHg concentrations, with potential driver variables. No correlations were detected between summer or fall reservoir-surface FHg 
concentrations and any of the ancillary constituents, antecedent precipitation, or land-use variables (tables 9 and 10). The only potential association between reservoir-water sample mercury concentrations and ancillary constituents was between reservoir-bottom winter TRHg and DO $(\rho=0.810$, $p=0.015$; table 9); however, reservoir-bottom TRHg concentrations exhibited significant and potential associations with several other potential driver variables. Reservoir-bottom summer TRHg concentrations were significantly associated with drainage area $(\rho=0.777, p=0.002$; table 10$)$ and were potentially associated with antecedent precipitation and all of the land-use variables (table 10). Reservoir-bottom winter TRHg concentrations were also potentially associated with antecedent precipitation; however, potential associations between reservoir-bottom winter TRHg concentrations and antecedent precipitation were positive in contrast with the potential associations between reservoir-bottom summer TRHg concentrations and antecedent precipitation, which were negative (table 10). TRHg in streams was positively associated with $\operatorname{TOC}_{\text {water }}(\rho=0.883, p=<0.001$; table 9$)$ and $\operatorname{SSC}(\rho=0.728$, $\mathrm{p}=0.005$; table 9 ) and potentially associated with streamflow
( $\rho=0.674, p=0.016$; table 9). Stream TRHg concentrations also exhibited a potential association with wetlands $(\rho=0.619$, $\mathrm{p}=0.018$; table 10).

Bed sediment THg was significantly associated with one potential driver variable and potentially associated with several potential driver variables (tables 11 and 12). For reservoir sites, bed sediment THg was significantly associated with the amount of precipitation within 7 days prior to sample collection $(\rho=0.708, p=0.003$; table 12$)$ and potentially associated with $\mathrm{SO}_{4}{ }^{2-}(\rho=-0.577, \mathrm{p}=0.024$; table 11$)$, drainage area $(\rho=-0.581, p=0.038$; table 12$)$, and $\operatorname{TOC}_{\text {sed }}(\rho=0.593$, $\mathrm{p}=0.020$; table 12). THg concentrations in bed sediment from streams were also potentially correlated with $\mathrm{TOC}_{\text {sed }}$, although the direction of the association differed from the direction of association between bed sediment $\mathrm{THg}$ and $\mathrm{TOC}_{\text {sed }}$ in reservoirs $(\rho=-0.610, p=0.027$; table 12$)$.

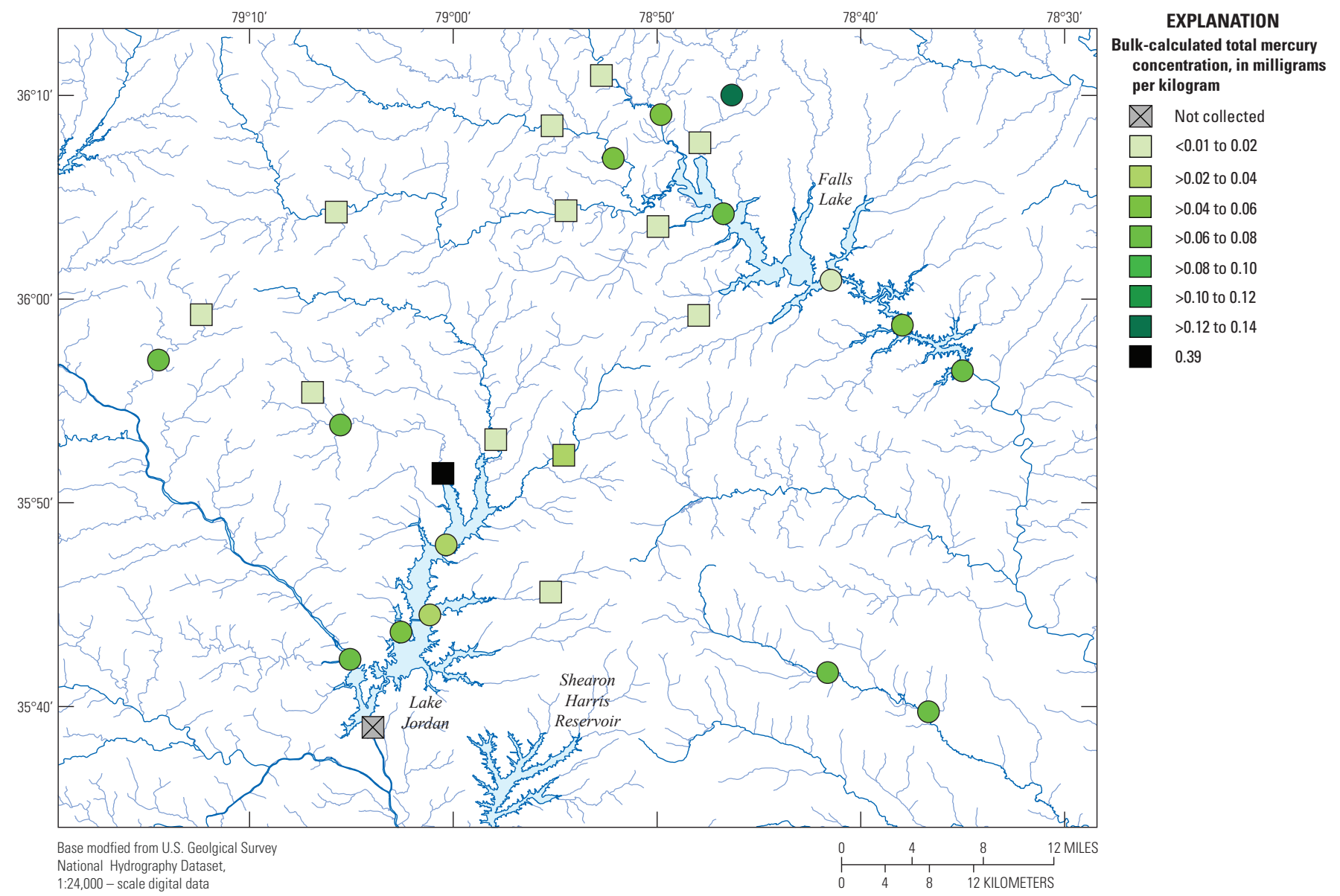

Figure 11. Map showing bed sediment bulk-calculated total mercury concentrations. Circles indicate reservoir sites; squares indicate stream sites. 
Table 9. Spearman rank correlations ( $\rho$, with $p$-value in parentheses) between median mercury concentrations and ancillary constituents for water samples.

[Mercury concentrations (FHg or TRHg) in samples in which FHg or TRHg were not detected were substituted with randomly generated values below the MDL for median computations. Abbreviations: FHg, filtered mercury; TRHg, total recoverable mercury; MDL, method detection level; DO, dissolved oxygen; SC, specific conductance; $\mathrm{SO}_{4}{ }^{2-}$, sulfate; Chloro $a$, chlorophyll $a$; Pheo $a$, pheophytin $a$; DOC, dissolved organic carbon; TOC ${ }_{\text {water, }}$ total organic carbon in water; $\mathrm{SSC}_{\text {, }}$ suspended-sediment concentration; NA, no association was calculated because of either no variability in potential driver variable values, or more than 50 percent of median values for correlative analysis were below the MDL; NM, not measured]

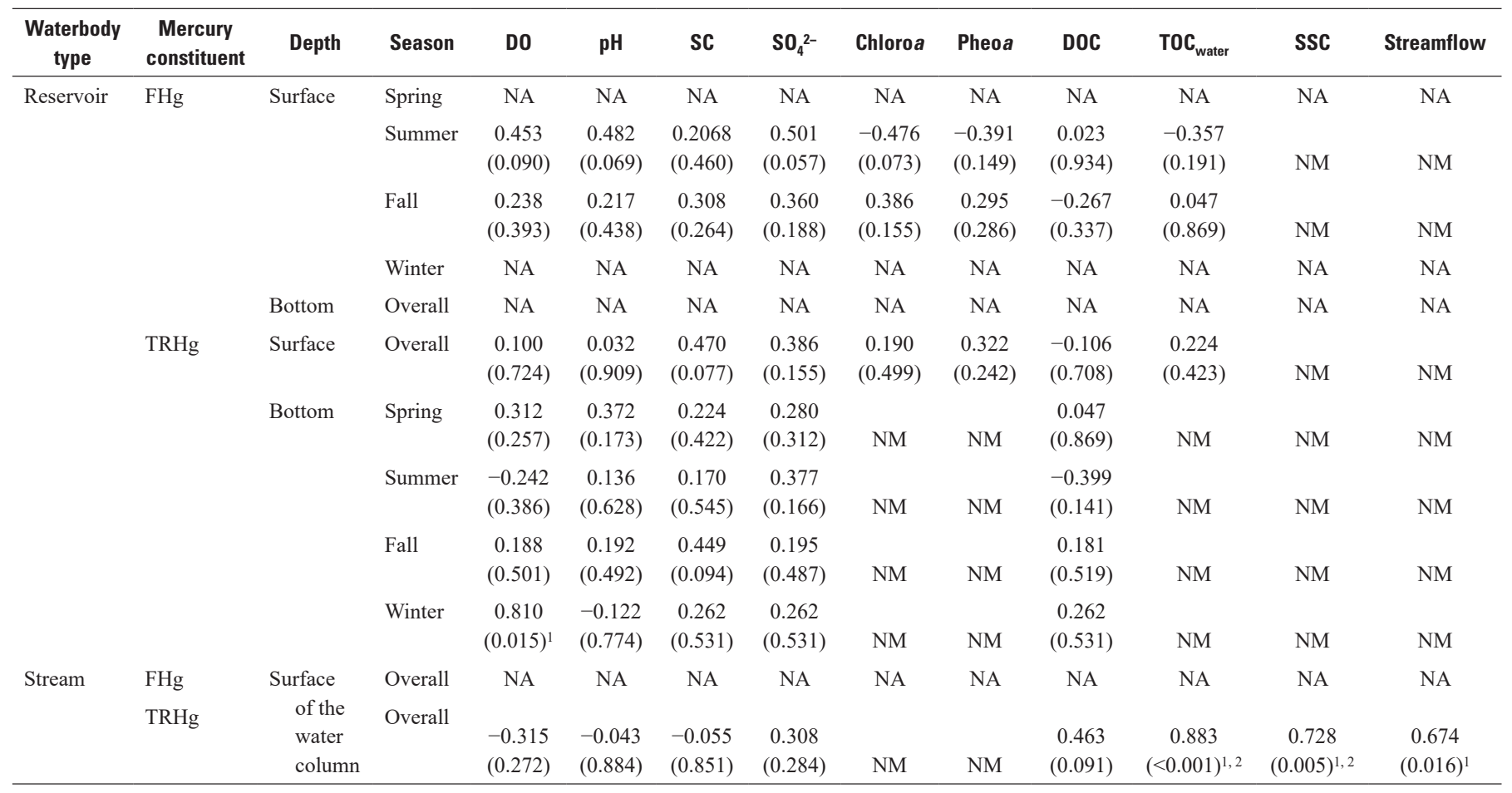

${ }^{1} \mathrm{p}<0.05$.

${ }^{2} \mathrm{p}<0.01$. 
Table 10. Spearman rank correlations (Spearman's $\rho$, with $p$-value in parentheses) for associations between seasonal median and overall median mercury concentrations and land use for reservoir and stream sites.

[Mercury concentrations (FHg or TRHg) for samples in which FHg or TRHg were not detected were substituted with randomly generated values below the MDL for median computations. Abbreviations: FHg, filtered mercury; TRHg, total recoverable mercury; MDL, method detection level; Precip, total precipitation antecedent to sample collection for the number of days listed; NA, no variability in potential driver variable values or more than 50 percent of median values for correlative analysis below the MDL]

\begin{tabular}{|c|c|c|c|c|c|c|c|c|c|c|c|}
\hline $\begin{array}{l}\text { Waterbody } \\
\text { type }\end{array}$ & $\begin{array}{c}\text { Mercury } \\
\text { constituent }\end{array}$ & Depth & Season & Precip $_{1 \mathrm{day}}$ & Precip $_{2 \text { day }}$ & Precip $_{7 \text { day }}$ & $\begin{array}{c}\text { Drainage } \\
\text { area }\end{array}$ & Urban & Forest & $\begin{array}{l}\text { Impervious } \\
\text { surface }\end{array}$ & Wetland \\
\hline \multirow[t]{7}{*}{ Reservoir } & \multirow[t]{3}{*}{$\mathrm{FHg}$} & \multirow[t]{3}{*}{ Surface } & Spring & NA & NA & NA & NA & NA & NA & NA & NA \\
\hline & & & Summer & $\begin{array}{l}-0.364 \\
(0.183)\end{array}$ & $\begin{array}{l}-0.468 \\
(0.079)\end{array}$ & $\begin{array}{l}-0.230 \\
(0.410)\end{array}$ & $\begin{array}{c}0.551 \\
(0.051)\end{array}$ & $\begin{array}{c}0.113 \\
(0.713)\end{array}$ & $\begin{array}{l}-0.154 \\
(0.615)\end{array}$ & $\begin{array}{c}0.094 \\
(0.761)\end{array}$ & $\begin{array}{c}0.501 \\
(0.081)\end{array}$ \\
\hline & & & Fall & $\begin{array}{l}-0.403 \\
(0.137)\end{array}$ & $\begin{array}{l}-0.265 \\
(0.340)\end{array}$ & $\begin{array}{l}-0.381 \\
(0.161)\end{array}$ & $\begin{array}{c}0.380 \\
(0.200)\end{array}$ & $\begin{array}{c}0.163 \\
(0.596)\end{array}$ & $\begin{array}{c}0.033 \\
(0.915)\end{array}$ & $\begin{array}{c}0.110 \\
(0.720)\end{array}$ & $\begin{array}{c}0.135 \\
(0.660)\end{array}$ \\
\hline & \multirow[t]{4}{*}{ TRHg } & Surface & Overall & NA & $\begin{array}{l}-0.618 \\
(0.014)^{1}\end{array}$ & $\begin{array}{l}-0.387 \\
(0154)\end{array}$ & $\begin{array}{c}0.534 \\
(0.060)\end{array}$ & $\begin{array}{c}0.270 \\
(0.373)\end{array}$ & $\begin{array}{l}-0.322 \\
(0.284)\end{array}$ & $\begin{array}{c}0.393 \\
(0184)\end{array}$ & $\begin{array}{c}0.344 \\
(0250)\end{array}$ \\
\hline & & \multirow[t]{3}{*}{ Bottom } & Spring & $\begin{array}{l}-0.034 \\
(0.903)\end{array}$ & $\begin{array}{c}0.100 \\
(0.722)\end{array}$ & $\begin{array}{l}-0.278 \\
(0.317)\end{array}$ & $\begin{array}{c}0.388 \\
(0.190)\end{array}$ & $\begin{array}{c}0.388 \\
(0.190)\end{array}$ & $\begin{array}{l}-0.363 \\
(0.223)\end{array}$ & $\begin{array}{c}0.465 \\
(0.109)\end{array}$ & $\begin{array}{c}0.452 \\
(0.121)\end{array}$ \\
\hline & & & Summer & $\begin{array}{l}-0.571 \\
(0.026)^{1}\end{array}$ & $\begin{array}{l}-0.631 \\
(0.012)^{1}\end{array}$ & $\begin{array}{l}-0.168 \\
(0.549)\end{array}$ & $\begin{array}{c}0.777 \\
(0.002)^{1,2}\end{array}$ & $\begin{array}{c}0.596 \\
(0.031)^{1}\end{array}$ & $\begin{array}{l}-0.580 \\
(0.038)^{1}\end{array}$ & $\begin{array}{c}0.555 \\
(0.049)^{1}\end{array}$ & $\begin{array}{c}0.671 \\
(0.012)^{1}\end{array}$ \\
\hline & & & Winter & $\begin{array}{c}0.203 \\
(0.630)\end{array}$ & $\begin{array}{c}0.792 \\
(0.019)^{1}\end{array}$ & $\begin{array}{c}0.807 \\
(0.015)^{1}\end{array}$ & $\begin{array}{l}-0.600 \\
(0.208)\end{array}$ & $\begin{array}{l}-0.029 \\
(0.957)\end{array}$ & $\begin{array}{l}-0.486 \\
(0.329)\end{array}$ & $\begin{array}{c}0.429 \\
(0.397)\end{array}$ & $\begin{array}{l}-0.314 \\
(0.544)\end{array}$ \\
\hline \multirow[t]{2}{*}{ Stream } & $\mathrm{FHg}$ & \multirow{2}{*}{$\begin{array}{l}\text { Surface of } \\
\text { the water } \\
\text { column }\end{array}$} & Overall & NA & NA & NA & NA & NA & NA & NA & NA \\
\hline & $\mathrm{TRHg}$ & & Overall & $\begin{array}{c}0.227 \\
(0.435)\end{array}$ & $\begin{array}{c}0.368 \\
(0.195)\end{array}$ & $\begin{array}{c}0.276 \\
(0.340)\end{array}$ & $\begin{array}{c}0.118 \\
(0.689)\end{array}$ & $\begin{array}{c}0.463 \\
(0.095)\end{array}$ & $\begin{array}{l}-0.313 \\
(0.276)\end{array}$ & $\begin{array}{c}0.490 \\
(0.075)\end{array}$ & $\begin{array}{c}0.619 \\
(0.018)^{1}\end{array}$ \\
\hline
\end{tabular}

${ }^{1} \mathrm{p}<0.05$.

${ }^{2} \mathrm{p}<0.01$. 
Table 11. Spearman rank correlations ( $\rho$, with $p$-value in parentheses) between bed sediment bulk-calculated total mercury concentrations and ancillary constituents for water samples collected simultaneously with bed sediment samples for reservoir and stream sites.

[Abbreviations: DO, dissolved oxygen; SC, specific conductance; $\mathrm{SO}_{4}{ }^{2-}$, sulfate; Chloro $a$, chlorophyll $a$; Pheo $a$, pheophytin $a$; DOC, dissolved organic carbon; $\mathrm{TOC}_{\text {water, }}$, total organic carbon in water; $\mathrm{SSC}$, suspended-sediment concentration]

\begin{tabular}{|c|c|c|c|c|c|c|c|c|c|c|c|}
\hline $\begin{array}{l}\text { Waterbody } \\
\text { type }\end{array}$ & $\begin{array}{l}\text { Sampling } \\
\text { depth }\end{array}$ & $\mathrm{pH}$ & DO & SC & $\mathrm{SO}_{4}{ }^{2-}$ & Chloroa & Pheoa & DOC & TOC $_{\text {water }}$ & SSC & Streamflow \\
\hline \multirow[t]{2}{*}{ Reservoir } & Surface & $-0.380(0.163)$ & $\begin{array}{c}0.145 \\
(0.606)\end{array}$ & $\begin{array}{l}-0.433 \\
(0.107)\end{array}$ & $\begin{array}{l}-0.492 \\
(0.063)\end{array}$ & $\begin{array}{l}-0.145 \\
(0.607)\end{array}$ & $\begin{array}{l}-0.464 \\
(0.081)\end{array}$ & $\begin{array}{l}-0.300 \\
(0.277)\end{array}$ & $\begin{array}{l}-0.281 \\
(0.310)\end{array}$ & NM & NM \\
\hline & Bottom & $\begin{array}{l}-0.300 \\
(0.278)\end{array}$ & $\begin{array}{l}0.2004 \\
(0.474)\end{array}$ & $\begin{array}{l}-0.441 \\
(0.100)\end{array}$ & $\begin{array}{l}-0.577 \\
(0.024)^{1}\end{array}$ & NM & NM & $\begin{array}{l}-0.411 \\
(0.128)\end{array}$ & NM & NM & NM \\
\hline Stream & $\begin{array}{l}\text { Surface of water } \\
\text { column }\end{array}$ & $0.370(0.214)$ & $\begin{array}{l}-0.291 \\
(0.335)\end{array}$ & $\begin{array}{c}0.415 \\
(0.151)\end{array}$ & $\begin{array}{c}0.503 \\
(0.080)\end{array}$ & NM & NM & $\begin{array}{l}-0.223 \\
(0.464)\end{array}$ & $\begin{array}{c}0.000 \\
(1.000)^{2}\end{array}$ & $\begin{array}{l}-0.600 \\
(0.400)\end{array}$ & $-0.169(0.620)$ \\
\hline
\end{tabular}

${ }^{1} \mathrm{p}<0.05$.

${ }^{2} \mathrm{TOC}_{\text {water }}$ measured in only 4 of 13 stream-water samples that were collected simultaneously with bed sediment samples.

Table 12. Spearman rank correlations ( $\rho$, with $p$-value in parentheses) for associations between bed sediment bulk-calculated total mercury concentrations and potential driver variables such as percentages of organic carbon in bed sediment, antecedent precipitation, drainage area, and land use.

[Abbreviations: $\mathrm{TOC}_{\mathrm{sed}}$, percentage of organic carbon in bed sediment; Precip, antecedent precipitation for the number of days preceding sample collection]

\begin{tabular}{lccccccccc}
\hline $\begin{array}{c}\text { Waterbody } \\
\text { type }\end{array}$ & TOC $_{\text {sed }}$ & Precip $_{\text {1day }}$ & Precip $_{2 \text { day }}$ & Precip $_{\text {7day }}$ & $\begin{array}{c}\text { Drainage } \\
\text { area }\end{array}$ & Urban & Forest & $\begin{array}{c}\text { Impervious } \\
\text { surface }\end{array}$ & $\begin{array}{c}\text { Wetland } \\
\text { Reservoir }\end{array}$ \\
& 0.593 & 0.009 & 0.346 & 0.708 & -0.581 & -0.228 & 0.415 & -0.404 & -0.490 \\
\multirow{2}{*}{ Stream } & $(0.020)^{1}$ & $(0.974)$ & $(0.206)$ & $(0.003)^{1,2}$ & $(0.038)^{1}$ & $(0.453)$ & $(0.158)$ & $(0.171)$ & $(0.089)$ \\
& -0.610 & -0.434 & 0.406 & -0.140 & -0.066 & -0.052 & 0.325 & 0.003 & 0.250 \\
& $(0.027)^{1}$ & $(0.138)$ & $(0.169)$ & $(0.647)$ & $(0.830)$ & $(0.865)$ & $(0.279)$ & $(0.993)$ & $(0.409)$ \\
\hline
\end{tabular}

${ }^{1} \mathrm{p}<0.05$.

${ }^{2} \mathrm{p}<0.01$.

\section{Discussion}

In this study, mercury concentrations in water and bed sediment samples from streams and reservoirs were measured and assessed for frequency of occurrences, concentrations, and exceedances relative to State, national, and international benchmark concentrations. Mercury levels were generally greater at reservoir sites than stream sites for both water and bed sediment samples, and mercury concentrations more frequently exceeded the NCWQC for mercury in reservoirs than in streams. The experimental design of this study, however, confounds an ecological interpretation of this comparison for water samples. Stream sites were most frequently sampled in the spring, when FHg concentrations in reservoir surfacewater samples and TRHg concentrations in reservoir bottomwater samples are relatively low. Stream sites were also least frequently sampled in the fall, when FHg concentrations in reservoir surface-water samples and TRHg concentrations in reservoir bottom-water samples are highest. If mercury concentrations in stream- and reservoir-water samples follow similar seasonal patterns, the overall detection and exceedance frequencies and median mercury concentrations may be biased low for streams and high for reservoirs.

At least 20 percent of surface samples from each reservoir site had TRHg concentrations exceeding the NCWQC for mercury, suggesting that mercury exceedances were not isolated in a limited number of sites in the Triangle Area. Similar inferences could be made on the basis of estimates of NCWQC exceedances made by using FHg concentrations that exceeded the NCWQC in reservoir surface-water samples; at least one sample collected in all but two reservoir sites exceeded the NCWQC. FHg concentrations did not exceed the NCWQC for mercury in any stream sites; this result could indicate that mercury concentrations were generally low in streams. Alternatively, the lack of FHg concentrations exceeding the NCWQC for mercury in stream samples may have been a result of the limited number of samples collected 
during the summer, or of samples collected in the five sites with TRHg exceedances of the NCWQC, where a high percentage of mercury in streams sites occurred in particulate form.

\section{Trends in Mercury Concentrations in Water and Bed Sediment}

Concentrations of mercury constituents in samples collected from reservoir depths that exhibited seasonal differences (FHg in reservoir-surface samples, TRHg in reservoir-bottom samples) were both highest in the fall. Atmospheric deposition peaks in the summer in the southeastern United States (Selin and Jacob, 2008), indicating that other factors besides atmospheric deposition are driving this trend. None of the investigated potential driver variables were associated with reservoir-surface FHg in the fall, nor were any associated with reservoir-bottom TRHg in the fall. Whereas the degree of reservoir mixing was assessed in this study by the strength and significance of correlations between surface and bottom mercury concentrations, other hydrologic factors (for example, inflows from stream and rivers) were not investigated. Wildman (2016) found that when inflow was high into a reservoir in Oklahoma, FHg concentrations were controlled by inflow hydrology, whereas biogeochemistry drove mercury flux when inflows were low through sequestration of mercury at the bottom of reservoirs under anoxic conditions. Similarly, Regnell (1994) found that under anoxic conditions and increased microbial activity, TRHg and $\mathrm{MeHg}$ concentrations increased in the water after release from the sediment. Low DO as a driver of TRHg in fall reservoir-bottom samples seems unlikely because TRHg concentrations were not associated with DO. TRHg in winter reservoir-bottom samples, however, were potentially positively associated with DO, which would not be expected if anoxic conditions had led to an increase in TRHg concentrations in bottom-water samples. Further analysis or additional studies to assess potential hydrologic influences on seasonal mercury trends may be warranted.

Summer TRHg concentrations in reservoir-bottom samples were significantly associated with drainage area. Potential associations between summer TRHg in reservoir-bottom samples and potential driver variables included (1) negative associations with precipitation one or two days prior to sample collection, (2) forest area, and (3) positive associations with urban, impervious-surface, and wetland areas. Atmospheric deposition is frequently the primary source of mercury in lake systems (Sorensen and others, 1990; USEPA, 1997b). The relationship between drainage-area and reservoir-bottom TRHg levels in the summer could be due to greater total masses of mercury deposited from the atmosphere in larger basins; at least some of this mercury would then be transported to reservoirs in runoff from impervious surfaces in the catchment (Lee and Iverfeldt, 1991; Brigham and others, 2009).
Potential associations between antecedent-precipitation and reservoir-bottom TRHg in the summer were negative, which would be contrary to expectation if wet deposition were a dominant source of mercury in reservoirs in the summer. Data collected between 2007 and 2009 from the National Atmospheric Deposition Program (NADP, 2020) site proximal to the Triangle Area (NC26, located in Candor, N.C.) indicated that TRHg concentrations in precipitation peaked in the summer with a median concentration of $0.014 \mu \mathrm{g} \cdot \mathrm{L}^{-1}$, (fig. 12) which was higher than the median summer TRHg concentrations in reservoir-bottom samples $\left(0.009 \mu \mathrm{g} \cdot \mathrm{L}^{-1}\right)$. This association might be an instance of a type I error or indicate an inverse relation between precipitation and summer TRHg concentrations in reservoir-bottom samples.

Mercury concentrations in streams are often a result of terrestrial processes (Brigham and others, 2009; Bradley and others, 2011). Litterfall can be a source of mercury inputs to streams equal to, if not more so, wet atmospheric deposition in fluvial systems (Journey and others, 2012). That TRHg in streams in this study was significantly associated with $\mathrm{TOC}_{\text {water }}$ and SSC suggests that inputs of particulate-bound mercury were dominant sources of mercury to stream systems. Mercury has a strong affinity for particulate organic matter (Haitzer and others, 2003; Brigham and others, 2009) and can bind to litterfall, which serves as an indirect input of mercury to streams from atmospherically derived mercury (Grigal, 2002; Journey and others, 2012; Bravo and others, 2018). Horowitz and Stephens (2008) also found that stream sites in basins with more than 50 percent forested cover had bed sediment mercury levels above levels measured at baseline sites (that is, population density below the 50th percentile and less than 5 percent urban) as a result of dry atmospheric deposition on leaf surfaces and possibly from higher levels of organic matter entering the streams. The mean percentage of forest cover in drainage basins in this study was 51 percent for reservoir sites (ranging from 3 to 72 percent) and 52 percent for stream sites (ranging from 16 to 73 percent). Whereas no association between mercury in stream water and forest cover was detected in this study, dry deposition on leaf cover from the abundant forested area at the study sites could be a possible source of mercury in bed sediment at the stream sites.

A potential positive association was also detected for stream TRHg (and reservoir-bottom summer TRHg) with wetland area. Numerous studies have noted associations between wetland abundance and $\mathrm{MeHg}$ (Wentz and others, 2014), which was not directly measured but would be included in the FHg and TRHg operational fractions if present. If wetlands are a source of $\mathrm{MeHg}$ in stream and reservoir systems in the Triangle Area, this relation might indicate that catchments with a higher percentage of wetland coverage have a higher ratio of $\mathrm{MeHg}$ to $\mathrm{TRHg}$ than catchments with less wetland coverage.

No association was detected between bulk-calculated bed sediment THg and land-use features except for a potential negative association with drainage area at reservoir sites. Sedimentation of particle-bound mercury is often the primary 
process that removes mercury in the water column (Sorensen and others, 1990; USEPA, 1997a). Marvin-DiPasquale and others (2009) found that in stream systems, the percentage of fines in bed sediment had a strong correlation $\left(\mathrm{r}^{2}=0.70\right)$ with bed sediment THg. A later exploration of the association between drainage area and the percentage of fines in reservoirbed sediment (defined as the percentage of sample grains less than $63 \mu \mathrm{m}$ in diameter) indicated that, with the exclusion of reservoir site 27 , the percentage of fines in sediment was generally greater for samples collected from reservoir sites with smaller drainage areas than those with larger drainage areas (Pearson's $r=0.588, p=0.0442$ ).

Bulk-calculated bed sediment $\mathrm{THg}$ concentrations in reservoirs were potentially negatively associated with $\mathrm{SO}_{4}{ }^{2-}$ in water samples from the bottom of the water column. Mercury flux at the sediment-water interface is influenced by numerous factors (Kudo and Hart, 1974; Dyrssen and Wedborg, 1991) that complicate an ecological interpretation of this result. Microbial methylation rates of mercury in bed sediment are generally highest in the top layer of bed sediment (Korthals and Winfrey, 1987). Sulfate-reducing bacteria in sulfate concentrations in bed sediment can affect rates of $\mathrm{MeHg}$ production (Langer and others, 2001). If the association between $\mathrm{THg}$ and $\mathrm{SO}_{4}{ }^{2-}$ is ecologically significant, one potential explanation could be that $\mathrm{SO}_{4}{ }^{2-}$ at the sediment-water interface is used by sulfate-reducing bacteria in the methylation and release of mercury from bed sediment to the water column.

The direction of association between $\mathrm{TOC}_{\text {sed }}$ and $\mathrm{THg}$ in bed sediment differed between reservoir and stream sites. THg in reservoir-bed sediments was positively associated with $\mathrm{TOC}_{\text {sed, }}$, whereas THg in stream-bed sediment was negatively associated with $\mathrm{TOC}_{\text {sed }}$. Many factors influence mercury flux in bed sediment (Kudo and Hart, 1974; Dyrssen and Wedborg, 1991), including organic carbon. For example, mercury is known to bind strongly with dissolved organic matter, which can affect the production and bioaccumulation of methylmercury (for review, see Ravichandran, 2004). Stream sites had relatively little variation in $\mathrm{TOC}_{\text {sed }}$ concentrations compared to reservoir sites. (The range of bulk-calculated THg in reservoir versus stream sites was $0.019-0.129$ [0.026 standard deviation] $\mathrm{mg} \cdot \mathrm{kg}^{-1}$ and $<0.001-0.035$ [0.010 standard deviation] $\mathrm{mg} \cdot \mathrm{kg}^{-1}$, respectively.) This lack of variation suggests that if the relationship between stream-bed sediment $\mathrm{THg}$ and $\mathrm{TOC}_{\text {sed }}$ were significant, any causative association had relatively little influence on THg concentrations in bed sediment.

Reservoir-bed sediment THg was also significantly correlated with antecedent precipitation during the seven days prior to sample collection. Mercury uptake in bed sediments can be influenced by factors including substrate type, presence of oxides, concentrations of mercury in water at the watersediment interface, and movement of water at the watersediment interface (Kudo and Hart, 1974; Jackson, 1989). Wet deposition or surface runoff and transport of litterfall may have resulted in higher concentrations of mercury in the water column. Kudo and Hart (1974) found that the rate of inorganic mercury uptake in bed sediment from the water-sediment interface was greatest when mercury was first introduced to the system. If precipitation resulted in direct or indirect inputs of mercury to the reservoirs, this input suggests that seven days may have been a long enough time window for mercury inputs to the reservoirs to be taken up by the bed sediment. 


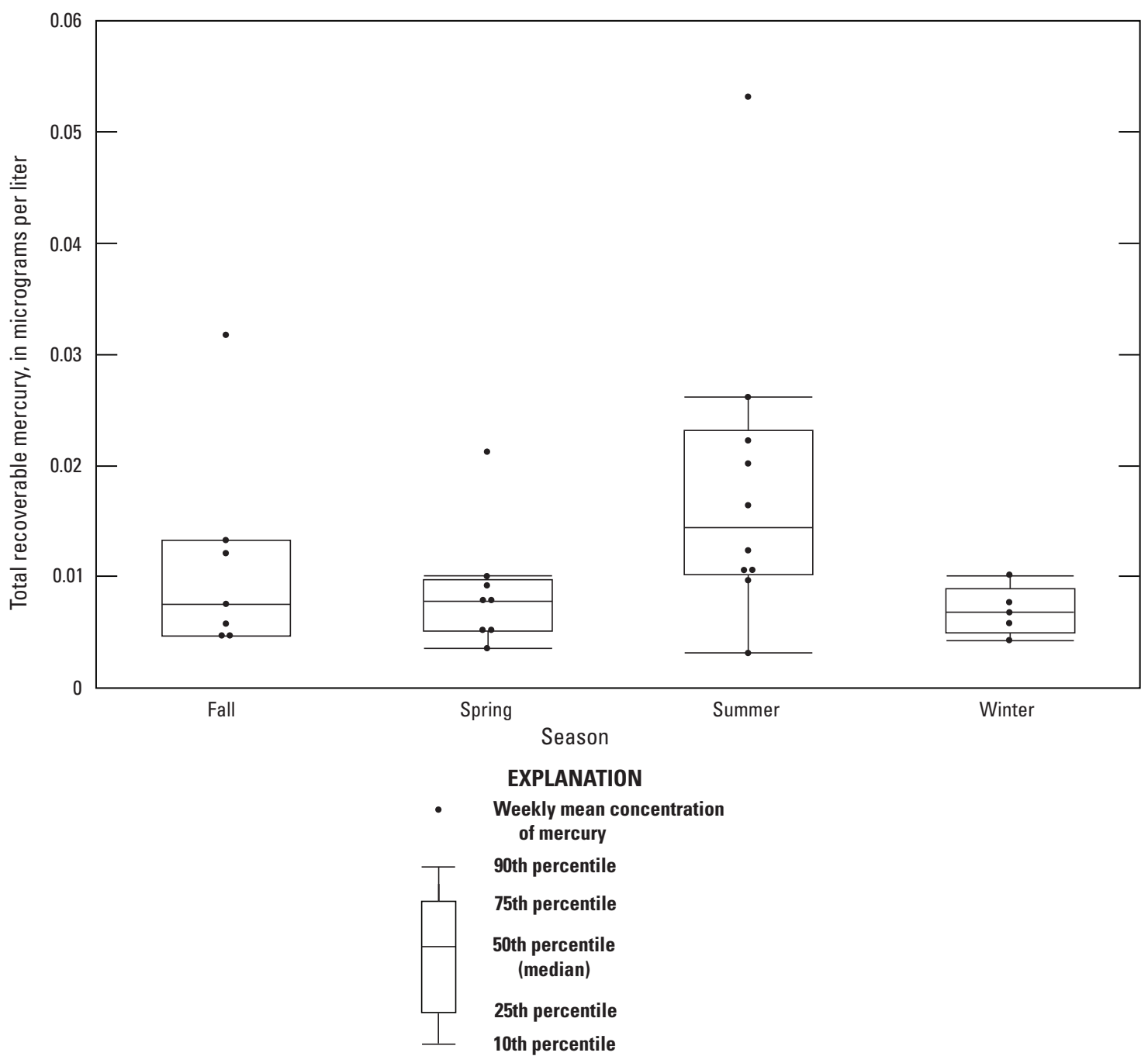

Figure 12. Boxplot showing weekly average concentrations of total recoverable mercury in precipitation samples collected between 2007 and 2009 from the National Atmospheric Deposition Program site in Candor, North Carolina.

\section{Comparisons of Mercury Concentrations with National and Benchmark Levels}

Mercury concentrations in water samples in this study were below levels associated with health risks to humans and aquatic biota. FHg and TRHg in all water samples were well below the USEPA national drinking-water regulatory criterion for mercury of $2 \mu \mathrm{g} \cdot \mathrm{L}^{-1}$ (USEPA, 2009). All FHg and TRHg concentrations in water samples were also below the TRHg aquatic-life criteria concentrations of $1.4 \mu \mathrm{g} \cdot \mathrm{L}^{-1}$ for acute exposure and $0.77 \mu \mathrm{g} \cdot \mathrm{L}^{-1}$ for chronic exposure (USEPA, 1996; Buchman, 2008). Mercury concentrations below the aquaticlife criteria are expected to prevent adverse effects associated with mercury exposure to fish, invertebrates, and other aquatic biota (USEPA, 1996).

At least one water sample from about one-half of the reservoir sites had a TRHg concentration similar to those measured in streams and lakes classified as having a significant on-site anthropogenic source of mercury.
TRHg concentrations in water collected during the last several decades of the 20th century from lakes and streams across the United States in areas with and without on-site significant anthropogenic sources (for example, mercury mines or industrial pollution) typically ranged from 0.1 to $0.4 \mu \mathrm{g} \cdot \mathrm{L}^{-1}$ and from 0.003 to $0.08 \mu \mathrm{g} \cdot \mathrm{L}^{-1}$, respectively (Wiener and others, 2003). TRHg mercury concentrations at the stream sites in this study all fell within the range for sites without significant anthropogenic sources; however, a total of 12 water samples from eight reservoir sites had TRHg concentrations in or above the range of those affected by anthropogenic sources. Six of these eight sites with relatively high TRHg concentrations in water samples were from Falls Lake and Jordan Lake. A study of mercury in the Sandy Creek catchment, which flows into Jordan Lake, suggested that the application of mercury-based fungicides to athletic fields at Duke University was a legacy source of mercury in the catchment (Deonarine and others, 2015). A concentration of $0.007 \mu \mathrm{g} \cdot \mathrm{L}^{-1} \mathrm{TRHg}$ was measured in water samples from the most downstream 
site on Sandy Creek, suggesting that this tributary was not a large source of mercury to Jordan Lake. They also suggested, however, that Sandy Creek may be a source of chronically low levels of $\mathrm{MeHg}$ that could bioaccumulate in fishes in Jordan Lake.

Background levels of mercury contamination refer to natural geochemical concentrations that are unaffected by human activity (Wentz and others, 2014). Background levels of mercury in freshwater sediment range between $<0.01$ and $0.05 \mathrm{mg} \cdot \mathrm{kg}^{-1}$ (Buchman, 2008; Horowitz and Stephens, 2008). Measured and bulk-calculated concentrations of THg in reservoir-bed sediment in this study generally exceeded $0.05 \mathrm{mg} \cdot \mathrm{kg}^{-1}$, a value that suggests that anthropogenic sources of mercury, such as atmospheric deposition, contribute to levels of mercury in bed sediment in Triangle-Area reservoirs. Total digestion was used to measure bed sediment $\mathrm{THg}$ concentrations in this study, indicating that mercury bound to the mineral matrix may have been included in the measurements as well as sorbed mercury. Horowitz and Stephens (2008) suggested that, relative to anthropogenic activities, the underlying rock type is unlikely to substantially influence sediment-associated mercury concentrations. The use of total digestion for measuring bed sediment mercury concentrations may have led to higher measurements than would functionally be available if geologic mercury bound to the matrix had been included in the measurement.

In contrast to background levels of a contaminant, baseline levels refer to concentrations of a contaminant for a specific area over a specific period of time and usually have some degree of anthropogenic influence (for example, atmospheric deposition; Park and others, 2008; Wentz and others, 2014). Samples collected by the USGS from 1991 to approximately 1999 indicated that baseline sediment THg concentrations ranged from 0.02 to $0.06 \mathrm{mg} \cdot \mathrm{kg}^{-1}$ for stream sites across the United States in catchments with population densities below the 50th percentile and areas with less than 5 percent urban land-use (Horowitz and Stephens, 2008; Wentz and others, 2014). Four stream-bed sediment samples in this study had measured $\mathrm{THg}$ concentrations that exceeded the baseline range of $0.02-0.06 \mathrm{mg} \cdot \mathrm{kg}^{-1}$ for stream sites across the United States (Horowitz and Stephens, 2008). Another national-scale USGS survey of THg in stream-bed sediment conducted between 1998 and 2005 found a mean of $0.09 \mathrm{mg} \cdot \mathrm{kg}^{-1}$ and median of $0.03 \mathrm{mg} \cdot \mathrm{kg}^{-1}$ for unmined basins (Scudder and others, 2009). The mean and median measured THg concentrations for streams in this study were $0.11 \mathrm{mg} \cdot \mathrm{kg}^{-1}$ and $0.05 \mathrm{mg} \cdot \mathrm{kg}^{-1}$, respectively. This indicates elevated levels of mercury in stream-bed sediment in the Triangle Area relative to levels in unmined basins during the time interval 1998-2005 (Scudder and others, 2009). Atmospheric-deposition rates of mercury are greater in the eastern half of the continental United States (east of the 98th meridian) compared to the western half (Shacklette and Boerngen, 1984; Gustavsson and others, 2001; Wentz and others, 2014). High rates of atmospheric deposition in the eastern United States could be one explanation for elevated THg concentrations in stream-bed sediment from the study area relative to concentrations at the national scale.
Adverse outcomes to sediment-dwelling organisms from exposure to elevated mercury levels in bed sediment were generally unlikely in the study area. Relative to benchmark standards indicative of health risks to aquatic biota, all bed sediment bulk-calculated mercury concentrations were below the probable-effect concentration of $1.06 \mathrm{mg} \cdot \mathrm{kg}^{-1}$, the concentration at which adverse effects to sediment-dwelling organisms are expected to occur more often than not (MacDonald and others, 2000). All bed sediment bulk-calculated mercury concentrations were also below the probable effect level of $0.486 \mathrm{mg} \cdot \mathrm{kg}^{-1}$, which is the concentration frequently associated with adverse effects to aquatic biota (Smith and others, 1996). Only one stream site had a bulk-calculated bed sediment THg above both the commonly used threshold for regulation in the United States of $0.18 \mathrm{mg} \cdot \mathrm{kg}^{-1}$ (USEPA, 2010) and the lowest effect level concentration of $0.20 \mathrm{mg} \cdot \mathrm{kg}^{-1}$ (the concentration at which ecotoxic effects become apparent; Canadian Ministry of Environment and Energy, 1993).

\section{Conclusions}

Seasonal trends and associations between potential driver variables and mercury concentrations suggest that atmospheric deposition is a primary source of mercury to reservoirs from both direct and indirect input from surface runoff, and that litterfall might be a primary source of mercury to streams in the Triangle Area. High concentrations of FHg and TRHg in the fall in some reservoir-water samples may warrant further analysis to determine potential hydrologic drivers of mercury concentrations in water. None of the analyses of water or bed sediment samples in this study indicated a severe or immediate risk to humans or aquatic biota; however, TRHg concentrations in surface-reservoir samples from the entire study area frequently exceeded the NCWQC for mercury. FHg concentrations, which served as conservative estimates of TRHg to control for the possibility of errors in TRHg measurements, exceeded the NCWQC for mercury in 25 percent of all reservoir-surface samples. Most of the water samples with TRHg concentrations in the general range for sites across the United States with on-site significant anthropogenic sources were from Jordan Lake and Falls Lake. These results might suggest that continued monitoring of these reservoirs is warranted. Mercury concentrations in stream-water and sediment samples were generally low relative to reservoir sites, and all stream TRHg concentrations were within the general range found across the United States for sites not affected by on-site mercury mines or industrial-pollution sources. The experimental design of the study, however, may have resulted in negative bias in overall mean and median FHg and TRHg concentrations of stream-water samples relative to overall mean and median FHg and TRHg concentrations in reservoir-water samples (or positive bias in reservoir-water samples relative to stream-water samples). Mercury concentrations in bed sediment from streams and reservoirs indicated that levels were 
elevated relative to baseline national levels. Higher rates of atmospheric deposition in the eastern half of the United States could be the cause of elevated THg levels in bed sediment in the study area relative to national baseline levels. Only one bed sediment sample had a bulk-calculated THg concentration above the commonly used guideline of $0.18 \mathrm{mg} \cdot \mathrm{kg}^{-1}$ in the United States. Future monitoring of bed sediment THg concentrations at this stream site with an anomalous THg concentrations may be warranted.

\section{References Cited}

Antweiler, R.C., and Taylor, H.E., 2008, Evaluation of statistical treatments of left-censored environmental data using coincident uncensored data sets-I. Summary Statistics: Environmental Science \& Technology, v. 42, no. 10, p. 3732-3738, accessed February 17, 2021, at https://doi.org/10.1021/es071301c.

Arar, E.J., and Collins, G.B., 1997, Method 445.0-In vitro determination of chlorophyll $a$ and pheophytin $a$ in marine and freshwater algae by fluorescence, Revision 1.2: Cincinnati, $\mathrm{OH}$, United States Environmental Protection Agency, Office of Research and Development.

Bradley, P.M., Burns, D.A., Murray, K.R., Brigham, M.E., Button, D.T., Chasar, L.C., Marvin-DiPasquale, M., Lowery, M.A., and Journey, C.A., 2011, Spatial and seasonal variability of dissolved methylmercury in two stream basins in the eastern United States: Environmental Science \& Technology, v. 45, no. 6, p. 2048-2055, accessed February 17, 2021, at https://doi.org/10.1021/es103923j.

Bravo, A.G., Kothawala, D.N., Attermeyer, K., Tessier, E., Bodmer, P., Ledesma, J.L., Audet, J., Casas-Ruiz, J.P., Catalán, N., Cauvy-Fraunié, S., Colls, M., Deininger, A., Evtimova, V.V., Fonvielle, J.A., Fuß, T., Gilbert, P., Herrero Ortega, S., Liu, L., Mendoza-Lera, C., Monteiro, J., Mor, J.-R., Nagler, M., Niedrist, G.H., Nydahl, A.C., Pastor, A., Pegg, J., Gutmann Roberts, C., Pilotto, F., Portela, A.P., González-Quijano, C.R., Romero, F., Rulík, M., and Amouroux, D., 2018, The interplay between total mercury, methylmercury and dissolved organic matter in fluvial systems - A latitudinal study across Europe: Water Research, v. 144, p. 172-182, accessed February 17, 2021, at https://doi.org/10.1016/j.watres.2018.06.064.

Brenton, R.W., and Arnett, T.L., 1993, Methods of analysis by the U.S. Geological Survey National Water Quality Laboratory-Determination of dissolved organic carbon by UV-promoted persulfate oxidation and infrared spectrometry: U.S. Geological Survey Open-File Report 92-480, 12 p.
Brigham, M.E., Wentz, D.A., Aiken, G.R., and Krabbenhoft, D.P., 2009, Mercury cycling in stream ecosystems. 1. Water column chemistry and transport: Environmental Science \& Technology, v. 43, no. 8, p. 2720-2725, accessed February 17, 2021, at https://doi.org/10.1021/es802694n.

Buchman, M.F., 2008, Screening quick reference tables (SQuiRTs): National Ocean Service, Office of Response Restoration Division Report 08-1, National Oceanic Atmospheric Administration, 34 p., accessed July 1, 2020, at https://response.restoration.noaa.gov/sites/default/files/ SQuiRTs.pdf.

Canadian Council of Ministers of the Environment, 1999, Canadian sediment quality guidelines for the protection of aquatic life: Mercury, Canadian Environmental Quality Guidelines, accessed June 16, 2020, at http://ceqg-rcqe.ccme.ca/download/en/241?redir=1592269076.

Canadian Ministry of Environment and Energy, 1993, Guidelines for the protection and management of aquatic sediment quality in Ontario, accessed June 30, 2020, at https://www.itrcweb.org/contseds-bioavailability/ References/guide_aquatic_sed93.pdf.

Clesceri, L.S., Greenberg, A.E., and Eaton, A.D., 1998, High-temperature combustion method 5310 B-Standard methods for the examination of water and wastewater, 20th edition: Washington, D.C., American Public Health Association, American Water Works Association, and Water Environment Federation.

Deonarine, A., Hsu-Kim, H., Zhang, T., Cai, Y., and Richardson, C.J., 2015, Legacy source of mercury in an urban streamwetland ecosystem in central North Carolina, USA: Chemosphere, v. 138, p. 960-965, accessed February 17, 2021, at https://doi.org/10.1016/j.chemosphere.2014.12.038.

Dyrssen, D., and Wedborg, M., 1991, The sulphur-mercury (II) system in natural waters: Water, Air, and Soil Pollution, v. 56, no. 1, p. 507-519, accessed February 17, 2021, at https://doi.org/10.1007/BF00342295.

Environment Canada, 1997, Canadian sediment quality guidelines for mercury-Supporting document: Environmental Conservation Service, Ecosystem Science Directorate, Science Policy and Environmental Quality Branch, Ottawa, Guidelines and Standards Division.

Fishman, M.J., and Friedman, L.C., eds., 1989, Methods for determination of inorganic substances in water and fluvial sediments: Techniques of Water-Resources Investigations 05-A1, $545 \mathrm{p}$.

Fitzgerald, S.A., 2020, Water and bed sediment data associated with the occurrence and distribution of mercury in streams and reservoirs in the Triangle Area of North Carolina, July 2007 - June 2009: U.S. Geological Survey data release, accessed February 17, 2021, at https://doi.org/10.5066/P9S4EMC7. 
Fitzgerald, W.F., Engstrom, D.R., Mason, R.P., and Nater, E.A., 1998, The case for atmospheric mercury contamination in remote areas: Environmental Science \& Technology, v. 32, no. 1, p. 1-7, accessed February 17, 2021, at https://doi.org/10.1021/es970284w.

Fry, J., Xian, G.S., Jin, S., Dewitz, J., Homer, C., Yang, L., Barnes, C., Herold, N., and Wickham, J., 2011, Completion of the 2006 National Land Cover Database for the conterminous United States: Photogrammetric Engineering and Remote Sensing, v. 77, p. 858-864.

Garbarino, J.R., and Damrau, D.L., 2001, Methods of analysis by the U.S. Geological Survey National Water Quality Laboratory-Determination of organic plus inorganic mercury in filtered and unfiltered natural water with cold vaporatomic fluorescence spectrometry: U.S. Geological Survey Water-Resources Investigation Report 01-4132, 16 p., accessed February 17, 2021, at https://doi.org/10.3133/ wri014132.

Garrett, R.G., Taylor, J.E., and Middleton, T.L., 1994, Water-quality data for selected North Carolina streams and reservoirs in the Triangle Area Water Supply Monitoring Project, 1988-92: U.S. Geological Survey Open-File Report 94-379, 255 p., accessed February 17, 2021, at https://doi.org/10.3133/ofr94379.

Grigal, D., 2002, Inputs and outputs of mercury from terrestrial watersheds-A review: Environmental Reviews, v. 10, no. 1, p. 1-39, accessed February 17, 2021, at https://doi.org/10.1139/a01-013.

Gustavsson, N., Bølviken, B., Smith, D.B., and Severson, R.C., 2001, Geochemical landscapes of the conterminous United States-New map presentations for 22 elements. U.S. Geological Survey Professional Paper 1648, 38 p., accessed February 17, 2021, at https://doi.org/10.3133/pp1648.

Haitzer, M., Aiken, G.R., and Ryan, J.N., 2003, Binding of mercury (II) to aquatic humic substances-Influence of $\mathrm{pH}$ and source of humic substances: Environmental Science \& Technology, v. 37, no. 11, p. 2436-2441, accessed February 17, 2021, at https://doi.org/10.1021/es026291o.

Horowitz, A.J., Elrick, K.A., and Smith, J.J., 2001, Estimating suspended sediment and trace element fluxes in large river basins-Methodological considerations as applied to the NASQAN programme: Hydrological Processes, v. 15, no. 7, p. 1107-1132, accessed February 17, 2021, at https://doi.org/10.1002/hyp.206.

Horowitz, A.J., and Stephens, V.C., 2008, The effects of land use on fluvial sediment chemistry for the conterminous USResults from the first cycle of the NAWQA Program-Trace and major elements, phosphorus, carbon, and sulfur: The Science of the Total Environment, v. 400, no. 1-3, p. 290-314, accessed February 17, 2021, at https://doi.org/10.1016/j.s citotenv.2008.04.027.
Jackson, T.A., 1989, The influence of clay minerals, oxides, and humic matter on the methylation and demethylation of mercury by micro-organisms in freshwater sediments: Applied Organometallic Chemistry, v. 3, no. 1, p. 1-30, accessed February 17, 2021, at https://doi.org/10.1002/ aoc. 590030103 .

Journey, C.A., Burns, D.A., Riva-Murray, K., Brigham, M.E., Button, D.T., Feaster, T.D., Petkewich, M.D., and Bradley, P.M., 2012, Fluvial transport of mercury, dissolved organic carbon, suspended sediment, and selected major ions in contrasting stream basins in South Carolina and New York, October 2004 to September 2009: U.S. Geological Survey Scientific Investigations Report 2012-5173, 125 p., accessed February 17, 2021, at https://doi.org/10.3133/ $\operatorname{sir} 20125173$.

Korthals, E.T., and Winfrey, M.R., 1987, Seasonal and spatial variations in mercury methylation and demethylation in an oligotrophic lake: Applied and Environmental Microbiology, v. 53, no. 10, p. 2397-2404, accessed February 17, 2021, at https://doi.org/10.1128/AEM.53.10.2397-2404.1987.

Krabbenhoft, D.P., and Rickert, D.A., 1995, Mercury contamination of aquatic ecosystems: U.S. Geological Survey Fact Sheet 216-95, $4 \mathrm{p}$.

Kudo, A., and Hart, J.S., 1974, Uptake of inorganic mercury by bed sediments: Journal of Environmental Quality, v. 3, no. 3, p. 273-278, accessed February 17, 2021, at https://doi.org/10.2134/jeq1974.00472425000300030019x.

Langer, C., Fitzgerald, W., Visscher, P., and Vandal, G., 2001, Biogeochemical cycling of methylmercury at Barn Island salt marsh, Stonington, CT, USA: Wetlands Ecology and Management, v. 9, no. 4, p. 295-310, accessed February 17, 2021, at https://doi.org/10.1023/A:1011816819369.

Lee, Y.-H., and Iverfeldt, Å., 1991, Measurement of methylmercury and mercury in run-off, lake and rain waters: Water, Air, and Soil Pollution, v. 56, no. 1, p. 309-321, accessed February 17, 2021, at https://doi.org/10.1007/ BF00342279.

MacDonald, D.D., Ingersoll, C.G., and Berger, T., 2000, Development and evaluation of consensus-based sediment quality guidelines for freshwater ecosystems: Archives of Environmental Contamination and Toxicology, v. 39, no. 1, p. 20-31, accessed February 17, 2021, at https://doi.org/ $10.1007 / \mathrm{s} 002440010075$.

Marvin-DiPasquale, M., Lutz, M.A., Brigham, M.E., Krabbenhoft, D.P., Aiken, G.R., Orem, W.H., and Hall, B.D., 2009, Mercury cycling in stream ecosystems. 2. Benthic methylmercury production and bed sedimentPore-water partitioning: Environmental Science \& Technology, v. 43, no. 8, p. 2726-2732, accessed February 17, 2021, at https://doi.org/10.1021/es802698v. 
Mason, R.P., Fitzgerald, W.F., and Morel, F.M.M., 1994, The biogeochemical cycling of elemental mercuryAnthropogenic influences: Geochimica et Cosmochimica Acta, v. 58, no. 15, p. 3191-3198, accessed February 17, 2021, at https://doi.org/10.1016/0016-7037(94)90046-9.

Mueller, D.K., Schertz, T.L., Martin, J.D., and Sandstrom, M.W., 2015, Design, analysis, and interpretation of field quality-control data for water-sampling projects: U.S. Geological Survey Techniques and Methods, book 4, chap. C4, 54 p., accessed February 17, 2021, at https://doi.org/10.3133/tm4C4.

National Atmospheric Deposition Program [NADP], 2020, MDN Site NC26: National Atmospheric Deposition Program MDN [Mercury Deposition Network] data, accessed April 27, 2021, at http://nadp.slh.wisc.edu/data/ sites/siteDetails.aspx?net=MDN\&id=NC26.

North Carolina Department of Environment and Natural Resources, 2007, Surface water and wetlands standards, subchapter 2B of Environment and natural resources: North Carolina Administrative Code, title 15A, accessed July 16, 2020, at https://files.nc.gov/ncdeq/Water\%20Quality/Planning/ CSU/Rules\%20webpage/RULE-ch2-sub2B-REDBOOK20070501-DWQ-PLN-CSU.pdf\#: : :text=surface $\%$ 20 waters $\% 20$ and $\% 20$ wetlands $\% 20$ standards $\% 20 \mathrm{nc} \% 20$ administrative $\% 20$ code. $0200 \% 20 \% 26 \% 20.0300 \% 20 \mathrm{am}$ ended $\% 20$ effective $\% 3 \mathrm{~A} \% 20$ may $\% 201 \% 2 \mathrm{C} \% 202007$.

North Carolina Department of Environment and Natural Resources, 2012, North Carolina Mercury TMDL: North Carolina Department of Environment and Natural Resources, 105 p., accessed May 27, 2020, at https://files.nc.gov/ncdeq/Water\%20Quality/Planning/ TMDL/FINAL\%20TMDLS/Statewide/NCMercuryTMDL_ EPASubmit.pdf.

Oblinger, C.J., 2004, Triangle Area Water Supply Monitoring Project, October 1988 through September 2001, North Carolina - Description of the water-quality network, sampling and analysis methods, and quality-assurance practices: U.S. Geological Survey Open-File Report 2004-1278, 65 p.

Oblinger, C.J., and Treece, M.W., Jr., 1996, Water and bed-material quality of selected streams and reservoirs in the Research Triangle area of North Carolina, 1988-94, U.S. Geological Survey Water-Resources Investigations Report 95-4282, accessed February 17, 2021, at https://doi.org/10.3133/wri954282.

Park, J.-S., Oh, S., Shin, M.-Y., Kim, M.-K., Yi, S.-M., and Zoh, K.-D., 2008, Seasonal variation in dissolved gaseous mercury and total mercury concentrations in Juam Reservoir, Korea: Environmental Pollution, v. 154, no. 1, p. 12-20, accessed February 17, 2021, at https://doi.org/ 10.1016/j.envpol.2007.12.002.
Rantz, S.E., and others, 1982, Measurement and computation of streamflow: U.S. Geological Survey Water Supply Paper 2175, 2 v., $631 \mathrm{p}$.

Ravichandran, M., 2004, Interactions between mercury and dissolved organic matter-A review: Chemosphere, v. 55, no. 3, p. 319-331, accessed February 17, 2021, at https://doi.org/10.1016/j.chemosphere.2003.11.011.

Regnell, O., 1994, The effect of $\mathrm{pH}$ and dissolved oxygen levels on methylation and partitioning of mercury in freshwater model systems: Environmental Pollution, v. 84, no. 1, p. 7-13, accessed February 17, 2021, at https://doi.org/ 10.1016/0269-7491(94)90064-7.

Scudder, B.C., Chasar, L.C., Wentz, D.A., Bauch, N.J., Brigham, M.E., Moran, P.W., and Krabbenhoft, D.P., 2009, Mercury in fish, bed sediment, and water from streams across the United States, 1998-2005: U.S. Geological Survey Scientific Investigations Report 2009-5109, 74 p., accessed February 17, 2021, at https://doi.org/10.3133/sir20095109.

Selin, N.E., and Jacob, D.J., 2008, Seasonal and spatial patterns of mercury wet deposition in the United StatesConstraints on the contribution from North American anthropogenic sources: Atmospheric Environment, v. 42, no. 21, p. 5193-5204, accessed February 17, 2021, at https://doi.org/10.1016/j.atmosenv.2008.02.069.

Shacklette, H.T., and Boerngen, J.G., 1984, Element concentrations in soils and other surficial materials of the conterminous United States: U.S. Geological Survey Professional Paper 1270, 105 p., accessed February 17, 2021, at https://doi.org/10.3133/pp1270.

Smith, S.L., MacDonald, D.D., Keenleyside, K.A., Ingersoll, C.G., and Jay Field, L., 1996, A Preliminary Evaluation of Sediment Quality Assessment Values for Freshwater Ecosystems: Journal of Great Lakes Research, v. 22, no. 3, p. 624-638, accessed February 17, 2021, at https://doi.org/ 10.1016/S0380-1330(96)70985-1.

Sorensen, J.A., Glass, G.E., Schmidt, K.W., Huber, J.K., and Rapp, G.R., Jr., 1990, Airborne mercury deposition and watershed characteristics in relation to mercury concentrations in water, sediments, plankton, and fish of eighty northern Minnesota lakes: Environmental Science \& Technology, v. 24 , no. 11, p. 1716-1727, accessed February 17, 2021, at https://doi.org/10.1021/es00081a015.

Turner, R.R., and Southworth, G.R., 1999, Mercurycontaminated industrial and mining sites in North America: an overview with selected case studies, in Ebinghaus, R., Turner, R.R., de Lacerda, L.D., Vasiliev, O., and Salomons, W., eds., Mercury contaminated sites: Berlin, Heidelberg, Springer, p. 89-112, accessed February 17, 2021, at https://doi.org/10.1007/978-3-662-03754-6_4. 
U.S. Environmental Protection Agency, [USEPA], 1996, 1995 updates - Water quality criteria documents for the protection of aquatic life in ambient water: U.S. Environmental Protection Agency Office of Water, EPA-820-B-96-001, accessed July 21, 2020, at https://www.epa.gov/sites/ production/files/2019-03/documents/1995-updates-wqcprotection-al.pdf.

U.S. Environmental Protection Agency, [USEPA], 1997a, Definition and procedure for the determination of the method detection limit-revision 1.11, appendix B of Guidelines establishing test procedures for the analysis of pollutants: U.S. Code of Federal Regulations, Title 40, revised July 1, 1997, p. 265-267.

U.S. Environmental Protection Agency, [USEPA], 1997b, Mercury Report to Congress: U.S. Environmental Protection Agency Office of Air Quality Planning and Standards and Office of Research and Development, EPA-452/R-97-003, accessed November 30, 2020, at https://www.epa.gov/ mercury/mercury-study-report-congress.

U.S. Environmental Protection Agency [USEPA], 2009, National primary drinking water regulations: U.S. Environmental Protection Agency Office of Groundwater and Drinking Water, EPA 816-F-09-004, accessed July 21, 2020, at https://www.epa.gov/sites/ production/files/2016-06/documents/npwdr_complete table.pdf.

U.S. Environmental Protection Agency [USEPA], 2010, Guidance on evaluating sediment contaminant results: Ohio Environmental Protection Agency, Division of Surface Water, Standards and Technical Support Section, 30 p., accessed November 30, 2020, at https://www.epa.ohio.gov/ portals/35/guidance/sediment_evaluation_jan10.pdf.

U.S. Geological Survey [USGS], 2016a, The StreamStats Program: U.S. Geological Survey, accessed December 29, 2020, at https://streamstats.usgs.gov/ss/.
U.S. Geological Survey [USGS], 2016b, USGS water data for the Nation: U.S. Geological Survey National Water Information System database, accessed April 27, 2021, at https://doi.org/10.5066/F7P55KJN.

U.S. Geological Survey [USGS], [variously dated], National field manual for the collection of water quality data, section A of Handbooks for water-resources investigations: U.S. Geological Survey Techniques of Water-Resources Investigations, book 9, 10 chap. (A0-A8, A10), accessed September 2, 2020, at https://pubs.water.usgs.gov/twri9A.

U.S. Geological Survey [USGS], [undated] a, USGS Quality Systems Branch: U.S. Geological Survey website, accessed April 27, 2021, at https://bqs.usgs.gov/.

U.S. Geological Survey [USGS], [undated] b, U.S. Geological Survey - Inorganic Blind Sample Project (IBSP): U.S. Geological Survey website, accessed April 27, 2021, at https://qsb.usgs.gov/ibsp/.

Wentz, D.A., Brigham, M.E., Chasar, L.C., Lutz, M.A., and Krabbenhoft, D.P., 2014, Mercury in the Nation's streamsLevels, trends, and implications: U.S. Geological Survey Circular 1395, 90 p., accessed February 17, 2021, at https://doi.org/10.3133/cir1395.

Wiener, J.G., Krabbenhoft, D.P., Heinz, G.H., and Scheuhammer, A.M., 2003, Ecotoxicology of Mercury, in Hoffman, D.J., Rattner, B.A., Burton, G.A., and Cairns, J., eds., Handbook of Ecotoxicology Boca Raton: Florida, CRC Press, p. 409-463.

Wildman, R.A., 2016, Mercury and methylmercury in a reservoir during seasonal variation in hydrology and circulation: Lake and Reservoir Management, v. 32, no. 1, p. 89-100, accessed February 17, 2021, at https://doi.org/10.1080/1 0402381.2015.1133740. 


\section{Appendix 1. Randomly Generated Numbers Below the Method Detection Level for Use in Statistical Analysis}

Table 1.1. Randomly generated numbers below the method detection level for use in statistical analysis.

[FHg, filtered mercury; TRHg, total recoverable mercuContinuedry; >, greater than; MDL, method detection level]

\begin{tabular}{|c|c|c|c|c|c|c|c|}
\hline Site & Collection date & $\mathrm{FHg}$ & TRHg & Site & Collection date & $\mathbf{F H g}$ & TRHg \\
\hline 1 & Oct. 2, 2007 & 0 & 0.004 & 6 & June 3, 2008 & 0 & 0.001 \\
\hline 1 & Dec. 3, 2007 & 0.001 & $>\mathrm{MDL}$ & 6 & Aug. 26, 2008 & 0 & 0.004 \\
\hline 1 & Apr. 2, 2008 & 0.001 & 0.002 & 6 & June 17, 2009 & 0.002 & $>\mathrm{MDL}$ \\
\hline 1 & June 2, 2008 & 0.005 & 0.002 & 7 & Aug. 28, 2007 & 0 & 0.005 \\
\hline 1 & Oct. 17,2008 & 0.005 & 0.001 & 7 & Oct. 18,2007 & 0.004 & 0 \\
\hline 1 & Dec. 10, 2008 & 0.002 & 0 & 7 & Oct. 18,2007 & 0 & 0.001 \\
\hline 1 & Feb. 12, 2009 & 0.005 & 0.001 & 7 & June 16, 2008 & 0.004 & $>\mathrm{MDL}$ \\
\hline 1 & Apr. 27, 2009 & 0.001 & 0 & 7 & Aug. 12, 2008 & 0.002 & $>\mathrm{MDL}$ \\
\hline 1 & June 8, 2009 & 0.001 & 0.002 & 7 & Oct. 3, 2008 & 0.001 & 0.004 \\
\hline 3 & Sept. 6, 2008 & 0.005 & $>\mathrm{MDL}$ & 7 & June 26, 2009 & 0.001 & 0 \\
\hline 3 & Mar. 1, 2009 & 0 & 0.003 & 7 & June 26, 2009 & 0.004 & 0.001 \\
\hline 3 & May 5, 2009 & 0 & 0.005 & 8 & Apr. 1, 2008 & 0.004 & $>\mathrm{MDL}$ \\
\hline 3 & May 19, 2009 & 0.004 & 0.005 & 8 & Dec. 12, 2008 & 0.003 & $>\mathrm{MDL}$ \\
\hline 3 & June 5, 2009 & 0.005 & $>\mathrm{MDL}$ & 8 & May 27, 2009 & 0 & 0.003 \\
\hline 3 & June 23, 2009 & 0.003 & 0.001 & 9 & Sept. 6, 2008 & 0.002 & $>\mathrm{MDL}$ \\
\hline 4 & Aug. 28, 2007 & 0 & 0 & 9 & Sept. 26, 2008 & 0.004 & $>\mathrm{MDL}$ \\
\hline 4 & Oct. 30, 2007 & 0.002 & $>\mathrm{MDL}$ & 9 & Jan. 6, 2009 & 0.002 & $>\mathrm{MDL}$ \\
\hline 4 & Apr. 30, 2009 & 0.002 & 0.004 & 10 & Feb. 5, 2009 & 0 & $>\mathrm{MDL}$ \\
\hline 4 & Apr. 30, 2009 & 0.002 & 0.001 & 10 & Apr. 15, 2009 & 0.004 & $>\mathrm{MDL}$ \\
\hline 4 & June 17, 2009 & 0.004 & $>\mathrm{MDL}$ & 10 & Apr. 15, 2009 & 0 & $>\mathrm{MDL}$ \\
\hline 5 & Sept. 6, 2008 & 0.002 & $>\mathrm{MDL}$ & 10 & June 23, 2009 & 0.003 & 0.001 \\
\hline 5 & May 12, 2009 & 0.001 & 0.004 & 10 & June 23, 2009 & 0.002 & 0.005 \\
\hline 6 & Aug. 28, 2007 & $>\mathrm{MDL}$ & 0 & 11 & Sept. 26, 2008 & 0.003 & $>\mathrm{MDL}$ \\
\hline 6 & Apr. 24, 2008 & 0.004 & $>\mathrm{MDL}$ & 11 & Feb. 18, 2009 & 0.001 & 0.004 \\
\hline 6 & June 3, 2008 & 0 & 0.001 & 11 & May 12, 2009 & 0.004 & 0.002 \\
\hline
\end{tabular}


Table 1.1. Randomly generated numbers below the method detection level for use in statistical analysis.—Continued

[FHg, filtered mercury; TRHg, total recoverable mercury; >, greater than; MDL, method detection level]

\begin{tabular}{|c|c|c|c|c|c|c|c|}
\hline Site & Collection date & $\mathbf{F H g}$ & TRHg & Site & Collection date & $\mathbf{F H g}$ & TRHg \\
\hline 12 & Aug. 13, 2007 & 0.001 & $>\mathrm{MDL}$ & 14 & Dec. 4, 2008 & 0.003 & 0.003 \\
\hline 12 & Feb. 11, 2008 & 0.001 & $>\mathrm{MDL}$ & 14 & Feb. 6, 2009 & 0.004 & 0 \\
\hline 12 & June 17, 2008 & 0.004 & 0.003 & 14 & Apr. 9, 2009 & 0.004 & $>\mathrm{MDL}$ \\
\hline 12 & June 17, 2008 & 0.001 & 0.004 & 14 & June 23, 2009 & 0.003 & $>\mathrm{MDL}$ \\
\hline 12 & Oct. 14, 2008 & 0.001 & $>\mathrm{MDL}$ & 15 & Aug. 29, 2007 & 0.004 & $>\mathrm{MDL}$ \\
\hline 12 & Oct. 14, 2008 & 0.004 & $>\mathrm{MDL}$ & 15 & Nov. 1, 2007 & 0 & 0 \\
\hline 12 & Dec. 5, 2008 & 0 & 0 & 15 & Nov. 1, 2007 & 0.003 & 0.003 \\
\hline 12 & Dec. 5, 2008 & 0 & 0.004 & 15 & Apr. 28, 2008 & 0.001 & 0.001 \\
\hline 12 & Feb. 4, 2009 & 0.004 & $>\mathrm{MDL}$ & 15 & Apr. 28, 2008 & 0.005 & 0 \\
\hline 13 & Aug. 14, 2007 & 0 & 0.004 & 15 & Aug. 21, 2008 & 0.001 & 0 \\
\hline 13 & Aug. 14, 2007 & 0 & 0.002 & 15 & Oct. 21,2008 & 0 & 0.004 \\
\hline 13 & Oct. 4, 2007 & 0.004 & 0.004 & 15 & Apr. 16, 2009 & 0.004 & $>\mathrm{MDL}$ \\
\hline 13 & Dec. 12, 2007 & 0.004 & 0.004 & 15 & Apr. 16, 2009 & 0.002 & $>\mathrm{MDL}$ \\
\hline 13 & Dec. 12, 2007 & 0.004 & 0.002 & 15 & June 19, 2009 & 0 & $>\mathrm{MDL}$ \\
\hline 13 & Feb. 11, 2008 & 0.001 & 0.005 & 16 & Aug. 29, 2007 & 0.004 & $>\mathrm{MDL}$ \\
\hline 13 & Feb. 11, 2008 & 0.001 & 0.004 & 16 & Aug. 29, 2007 & 0.001 & $>\mathrm{MDL}$ \\
\hline 13 & Apr. 9, 2008 & 0 & 0.005 & 16 & Nov. 1, 2007 & 0.005 & $>\mathrm{MDL}$ \\
\hline 13 & Apr. 10, 2009 & 0.002 & 0.004 & 17 & Aug. 20, 2007 & 0.004 & 0 \\
\hline 13 & June 23, 2009 & 0.004 & $>\mathrm{MDL}$ & 17 & Feb. 6, 2008 & 0.003 & 0.003 \\
\hline 14 & Aug. 14, 2007 & 0 & 0.002 & 17 & June 2, 2008 & 0.003 & 0 \\
\hline 14 & Aug. 14, 2007 & 0.005 & 0.004 & 17 & Aug. 4, 2008 & 0.003 & 0.004 \\
\hline 14 & Oct. 4, 2007 & 0.003 & $>\mathrm{MDL}$ & 17 & Oct. 17,2008 & 0.004 & 0 \\
\hline 14 & Oct. 4, 2007 & 0.002 & $>\mathrm{MDL}$ & 17 & Dec. 10, 2008 & 0.002 & 0.001 \\
\hline 14 & Dec. 12, 2007 & 0 & 0.005 & 17 & Feb. 12, 2009 & 0.001 & 0.004 \\
\hline 14 & Dec. 12, 2007 & 0.001 & 0.002 & 17 & Apr. 27, 2009 & 0.001 & 0.004 \\
\hline 14 & Feb. 11, 2008 & 0.004 & 0.005 & 17 & June 15, 2009 & 0 & 0.001 \\
\hline 14 & Feb. 11, 2008 & 0.001 & 0.005 & 18 & Aug. 31, 2007 & 0 & $>\mathrm{MDL}$ \\
\hline 14 & Apr. 9, 2008 & 0.003 & 0.004 & 18 & Oct. 5, 2007 & 0.003 & 0.003 \\
\hline 14 & Apr. 9, 2008 & 0 & 0.005 & 18 & Oct. 5, 2007 & 0.002 & 0.004 \\
\hline 14 & June 18, 2008 & 0.002 & $>\mathrm{MDL}$ & 18 & Apr. 21, 2008 & 0.001 & 0 \\
\hline 14 & Oct. 15,2008 & 0 & $>\mathrm{MDL}$ & 18 & Apr. 21, 2008 & 0.003 & 0.002 \\
\hline 14 & Dec. 4, 2008 & 0.005 & 0.003 & 18 & June 26, 2008 & 0 & $>\mathrm{MDL}$ \\
\hline
\end{tabular}


Table 1.1. Randomly generated numbers below the method detection level for use in statistical analysis.-Continued

[FHg, filtered mercury; TRHg, total recoverable mercury; >, greater than; MDL, method detection level]

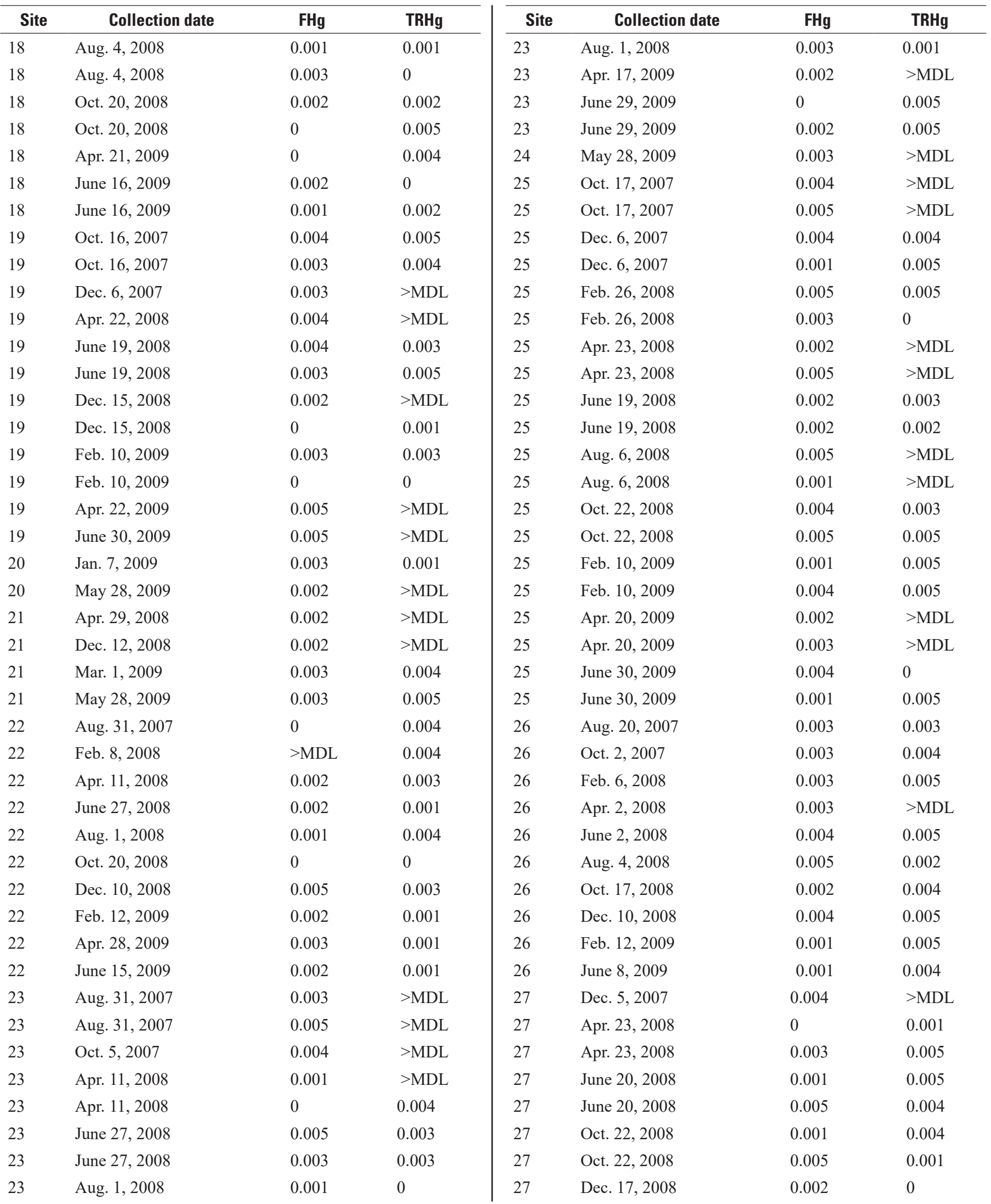


Table 1.1. Randomly generated numbers below the method detection level for use in statistical analysis.-Continued

[FHg, filtered mercury; TRHg, total recoverable mercury; >, greater than; MDL, method detection level]

\begin{tabular}{llll}
\hline Site & \multicolumn{1}{c}{ Collection date } & FHg & TRHg \\
\hline 27 & Dec. 17, 2008 & 0.004 & 0.002 \\
27 & Feb. 11, 2009 & 0.002 & 0.004 \\
27 & Apr. 23, 2009 & 0.001 & $>$ MDL \\
27 & Apr. 23, 2009 & 0 & 0.005 \\
28 & Oct. 17, 2007 & 0.001 & $>$ MDL \\
28 & Dec. 5, 2007 & 0.003 & 0.004 \\
28 & Dec. 5, 2007 & 0.002 & 0.003 \\
28 & Feb. 27, 2008 & 0.002 & $>$ MDL \\
28 & Apr. 23, 2008 & 0.003 & $>$ MDL \\
28 & June 20, 2008 & 0.003 & $>$ MDL \\
28 & Dec. 17, 2008 & 0.004 & $>\mathrm{MDL}$ \\
28 & Dec. 17, 2008 & 0.002 & 0.004 \\
28 & Feb. 11, 2009 & 0.003 & $>$ MDL \\
28 & Feb. 11, 2009 & 0.004 & 0.004 \\
28 & Apr. 23, 2009 & 0.002 & 0 \\
28 & Apr. 23, 2009 & 0.003 & 0.005 \\
28 & June 29, 2009 & 0.004 & $>$ MDL \\
29 & Apr. 29, 2008 & 0.005 & 0.002 \\
\hline
\end{tabular}




\section{Appendix 2. Accuracy of Bed Sediment Total Mercury and Total Organic-Carbon Analyses Determined for Reference Materials}

Table 2.1. Accuracy of bed sediment total mercury and total organic carbon analyses determined for reference materials.

[Data are from Fitzgerald (2020). NIST, National Institute of Standards and Technology; NRC, Nuclear Regulatory Commission; $\mathrm{mg}^{\mathrm{kg}} \mathrm{kg}^{-1}$, milligram per kilogram; \pm , plus or minus; - , not determined; wt. \%, weight percent; $<$, less than; RSD, relative standard deviation]

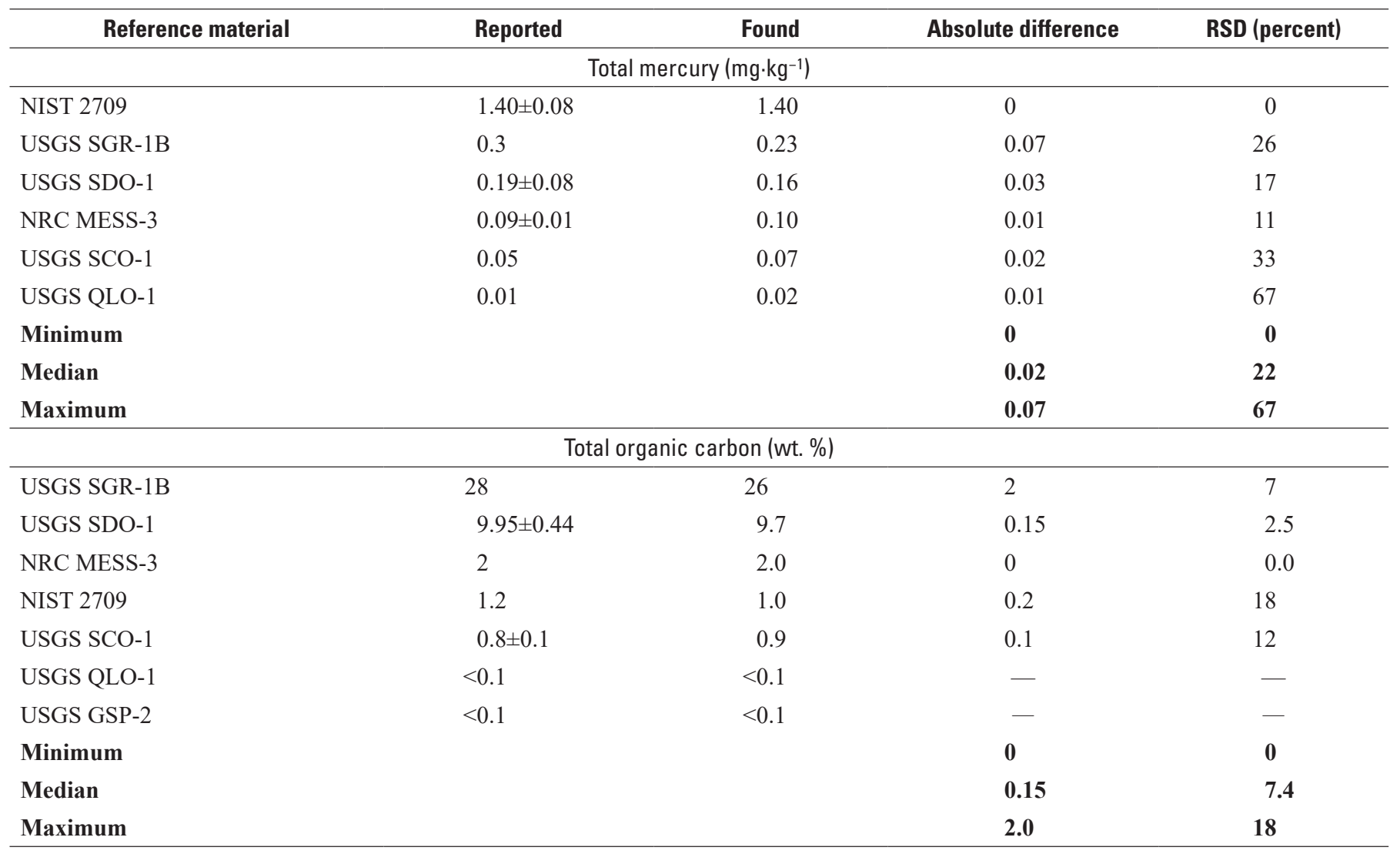




\section{Appendix 3. Precision of Constituent Analyses in Replicate Water Samples}

Table 3.1. Precision of constituent analyses in replicate water samples.

[RPD, relative percent difference; RSD, relative standard deviation; $\mu \mathrm{g} \cdot \mathrm{L}^{-1}$, microgram per liter; $\mathrm{mg} \cdot \mathrm{L}^{-1}$, milligram per liter, NA, not applicable]

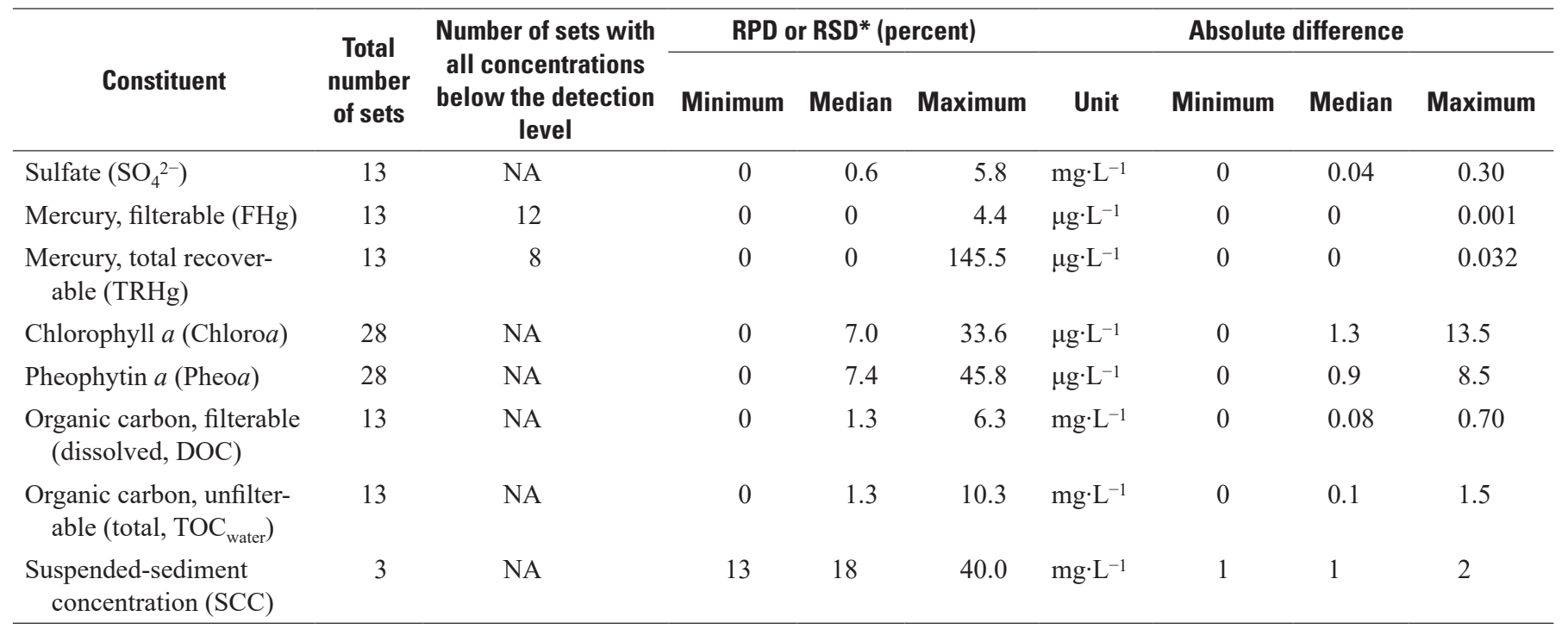

*RPD was calculated for two replicates, and RSD was calculated for three replicates. 
For more information about this publication, contact: Director, South Atlantic Water Science Center

U.S. Geological Survey

1770 Corporate Drive, Suite 500

Norcross, GA 30093

For additional information visit https://www.usgs.gov/centers/sa-water

Prepared by the USGS Science Publishing Network

Reston and Pembroke Publishing Service Centers 


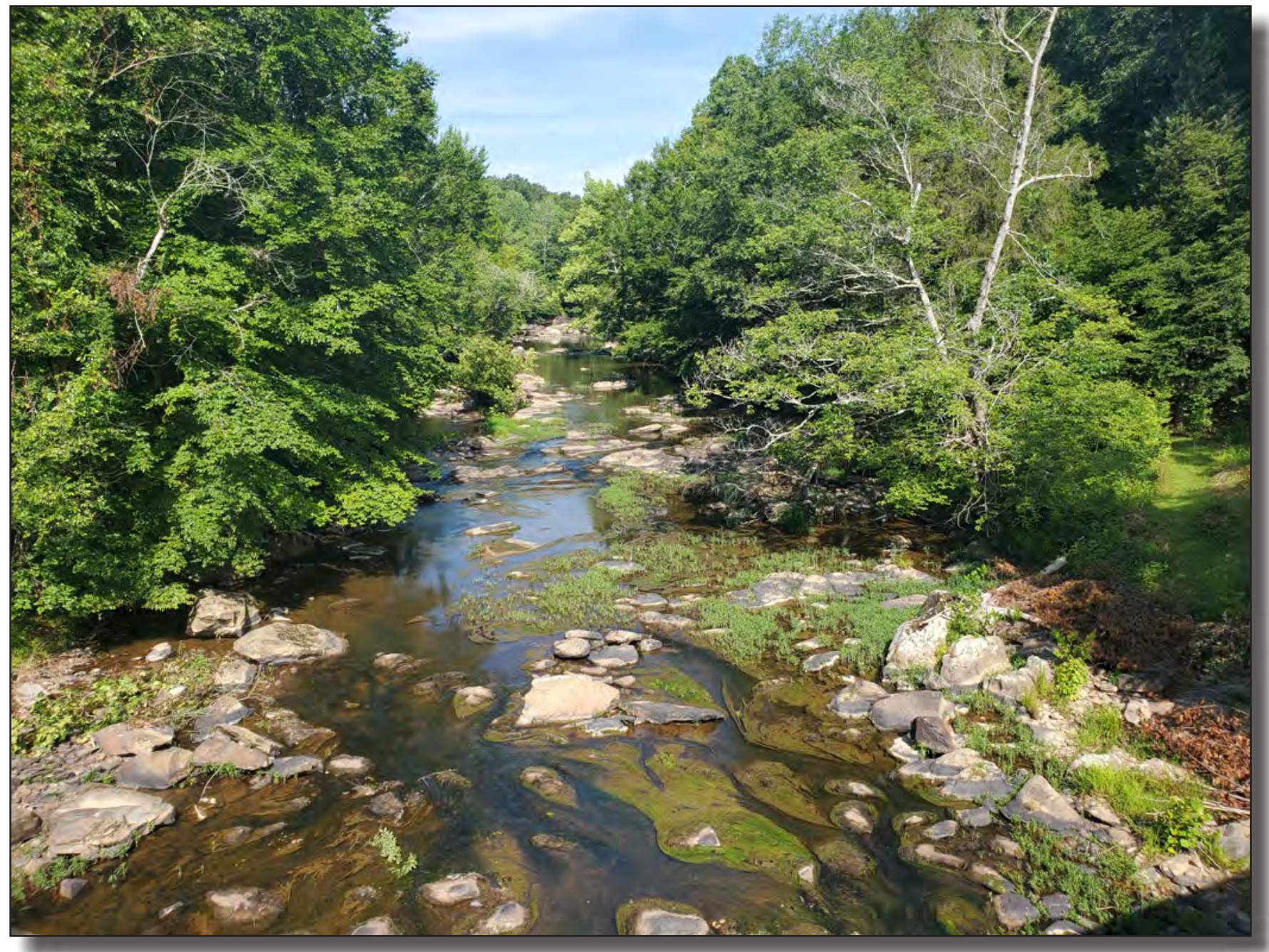

